\title{
5 Recent Market Practices
}

\subsection{General Remarks}

State regulation is complemented by market practices. State regulation facilitates market structures and transactions by laying down "the rules of the game", but the game actually played is defined by market practices as well. Market practices have belonged to the core drivers of the development of commercial law in the past. ${ }^{1}$

In this Chapter, we can have a brief look at some of the recent market practices, namely practices contributing to the lack of companies with publicly-traded shares (section 5.2), the practices of angel investors, venture capital firms, and investment funds (section 5.3), practices relating to the organisation of SME exchanges (section 5.4), the use of private listings and SPACs (section 5.5), the new role of social media in the GameStop case (section 5.6), and practices relating to the structure and composition of the board (section 5.7). We will use historical and recent practices as inspiration for future regulation in the second part of this book (Chapter 6).

The market practices of firms can be the result of many things. In the stock market, they reflect the interests of firms, the quality of shareholders as providers of funding and ancillary services, the quality of exchanges as providers of trading opportunities and ancillary services, and other things. From the perspective of the firm, the firm can be regarded as the principal of the principal-agent theory, and other parties can be regarded as the firm's agents (sections 2.3.3, 2.4.16 and 2.5).

\subsection{Lack of Companies with Publicly-Traded Shares}

A stock exchange listing is assumed to bring many benefits to public companies. For example, a SEC registration is said to allow public companies "to issue more shares, to issue public debt under favorable conditions, and to use their equity as

1 See, for example, Goode RM (1998) p 38: "It is through the rules and practices of the organised market, and from the market's power and competitive thrust, that the fullest play can be given to the creative genius of the merchant and his lawyer. The rules and usages of the market bind the participants to common standards and practices. They bolt a mass of bilateral contracts onto a framework of standard terms, each participant undertaking to the others to observe the rules of the market.”

Ә OpenAccess. (C) 2022 Petri Mäntysaari, published by De Gruyter. (cc))BY-NC-ND This work is licensed under the Creative Commons Attribution-NonCommercial-NoDerivatives 4.0 International License. https://doi.org/10.1515/9783110761108-006 
a form of currency to make acquisitions. It allows insiders to reduce their stakes and to diversify their holdings."2

However, there are relatively few listed companies in the world (section 1.3). Firms prefer to remain private, go private, or merge for many reasons. ${ }^{3}$ A growth firm and its founders may benefit more from avoiding public markets. Interesting growth firms can raise enough capital through private placements, do not want public debt, can use their equity as a form of currency to employ key people and to make acquisitions, and can choose better ways than an IPO for insiders to exit the company. The fact that big firms have a competitive advantage makes it rational for small firms to create greater operating profits by selling out in a trade sale. ${ }^{4}$ Moreover, listed companies can be taken over. ${ }^{5}$

There have been many attempts to build theories to describe the phenomenon of low IPO levels. ${ }^{6}$ The decline of IPOs seems to be the result of powerful market forces. ${ }^{7}$ We can have a brief look at some of the factors that have contributed to low IPO levels. They include the predominance of small firms, the competitive advantage of private firms, the increasing weight of intangible assets, the equity funding practices of start-ups, the easier availability of private capital, the useful services of venture capitalists, high valuations achieved in trade sales and private equity transactions, the high costs of IPOs and regulatory compliance,

2 Doidge C, Kahle KM, Karolyi GA (2018) p 14.

3 See Special Study of Securities Markets (1963a) pp 491-492; Jensen MC (1989); Gao X, Ritter JR, Zhu Z (2013); Hanley KW (2018); Díez FJ, Leigh D, Tambunlertchai S (2018); Kahle KM, Stulz RM (2017); Doidge C, Kahle KM, Karolyi GA (2018); Ewens M, Farre-Mensa J (2020); FESE (2019) p 5; Nicole Bullock, The reasons for a stagnating US public equity listings market. Financial Times, 17 May 2017.

4 Gao X, Ritter JR, Zhu Z (2013); Diez FJ, Leigh D, Tambunlertchai S (2018).

5 Reddy B (2020): “[I]t does not appear that the UK public equity markets are providing a stable, long-term home for UK tech-companies."

6 Rose P, Solomon SD (2016) p 83: "The most prominent theory offered for the drop in small company IPOs, a regulatory theory, posits that the drop is related to federal regulatory choices, including the Sarbanes-Oxley Act of 2002 (Sarbanes-Oxley). Other theories offer differing or complementary explanations. A theory, often paired with the regulatory theory, posits that heightened regulatory enforcement via public and private litigation has stunted the small IPO market. Market structure theories build on the regulatory explanation to assert that subsequent shifts in market structure have set up economic barriers to small company IPOs. Finally, economic scope theory posits that the cause of the small IPO's demise is neither related to regulation nor the structure of our capital markets, but rather due to shifting economic conditions that have provided alternative outlets for small IPOs.”

7 See ibid. 
and the low quality of shareholders in public markets. The list is not exhaustive. Other reasons range from the lack of analyst coverage to unfavourable tax laws. ${ }^{8}$

Small private firms. Most firms in the world are small entrepreneurial or family businesses. Family businesses made up more than $60 \%$ of all European companies according to a 2009 study. ${ }^{9}$ Relatively few companies in the world can fulfil the requirements for admission to trading on a traditional stock exchange. Traditional listing rules are designed for large established limited-liability companies with a dispersed share ownership structure.

The competitive advantage of private firms. The current regulatory framework for companies with publicly-traded shares does not seem to increase their competitiveness against private firms. ${ }^{10}$

A stock exchange listing does not seem to reduce funding costs. As regards the financing of young firms, private markets are much more important than public markets. ${ }^{11}$ Generally, firms rarely use public equity markets in order to raise cash. ${ }^{12}$

Moreover, the current legal framework for listed companies hampers management discretion especially when it reflects the financial business model and shareholder primacy (section 2.4.13). One may note that self-imposed unilateral constraints increase the likelihood of defeat according to Carl von Clausewitz, a nineteenth-century Prussian general. ${ }^{13}$

Private firms thus have access to funding without the obligations of public firms and may make investments according to what makes business sense for the firm, whereas public firms have more obligations and are expected to distribute funds to market investors. ${ }^{14}$

8 See Rose P, Solomon SD (2016) p 91 on the impact of Regulation FD on analyst coverage. See also FESE (2019) p 5: "Why is this happening? The reasons are manifold, and it will take a holistic, coherent and well-coordinated policy effort” [in the EU's CMU to address them].

9 European Commission (2009).

10 Jensen MC (1989).

11 Doidge C, Kahle KM, Karolyi GA (2018).

12 Mayer C (1990).

13 von Clausewitz C (1832).

14 See also de Fontenay E (2017) p 448: "From their inception, the federal securities laws proposed a simple bargain to U.S. companies: disclosure in exchange for investors. Companies that went public took on the obligation of publicly disclosing substantial amounts of information and, in return, were permitted to solicit the largest (and therefore cheapest) source of capital: the general public. Conversely, private companies were restricted to raising capital primarily from insiders and financial institutions, without publicity and subject to severe limitations on subsequent transfers of their securities - effectively precluding any sort of market for private company equity ... Over the last three decades, the disclosure bargain has largely been revoked. 
Small-cap companies generally do not seem to benefit from a stock exchange listing as much as large-cap companies do. Rose and Solomon have pointed out that "small-cap companies are different than large-cap companies. They have a shorter life span, are more likely to be involuntarily delisted, and are usually delisted for different reasons than the larger companies. More interestingly, the small-cap companies that stay listed tended to remain small."15

Intangible assets and the funding practices of technology start-ups. Growth firms can stay private longer because of new funding practices. On one hand, many start-ups may need less funding than in the past. On the other, technology start-ups may need more funding and have recently been able to raise larger amounts as seed funding.

Start-ups may need less funding because of technological advancement. Coyle and Green sum it up as follows: "[A] confluence of developments in technology - including cloud-based servers, cloud-based software, and open-source code - substantially reduced the costs of launching a technology-based start-up, beginning in approximately 2005. At the same time, a number of other factors including the improved accessibility of high-speed Internet and the increased popularity of social media - enabled these same companies to rapidly achieve significant scale."16

Moreover, start-ups may need less funding because of the increasing weight of intangible assets: "[I]ntangible assets, and in particular human capital, often are a significant driver of long-term value in today's global economy. In 1988, the largest 500 U.S. companies had a ratio of intangible assets to market capitalization of 8.5 percent-that ratio was 29.7 percent in 2018."17 The increasing weight of intangible assets is connected to the increasing scalability of business in digital economy. Intangible assets are scalable in a way that tangible assets are not. $^{18}$

This said, some start-ups may need more funding. The race to grow and create positive network effects has increased the amounts of funding that a technology start-up may have to raise in order to survive in the platform economy. More-

By repeatedly loosening the restrictions on capital raising and trading on the private side, securities regulators have given birth to a contradiction in terms: private securities markets. Today, private companies can raise ample, cheap capital with relative ease. Public company issuers therefore benefit significantly less from their disclosure obligations and can justifiably complain of a regulatory bait-and-switch."

15 Rose P, Solomon SD (2016) p 120.

16 Coyle JF, Green JM (2014) p 157.

17 Clayton J (2019).

18 Doidge C, Kahle KM, Karolyi GA (2018) p 15. 
over, SMEs may need more equity funding. While intangible assets make up an increasing share of SMEs' assets generally, their value is difficult to assess. For this and other reasons, it can be difficult for SMEs to raise debt. ${ }^{19}$

Technology start-ups nowadays try to raise more seed funding as was described by Coyle and Green: "[I]t now makes great economic sense, from a founder's perspective, to raise a more substantial seed round than was previously the case because of how much more the founder can achieve with those amounts and how it better positions the company for a subsequent round of financing."20

Availability of private capital. There is plenty of private capital looking for companies to invest in. Growing technology companies seldom need an IPO to raise funding. For example, Blockchain, the developer of Bitcoin, raised traditional venture capital funding. ${ }^{21}$ It chose neither an IPO nor an ICO to raise funding. ${ }^{22}$ Because of venture capital, firms do not have to turn to market investors and companies can stay private longer. ${ }^{23}$

In the US, there is a contrast between the over-regulation of public offerings and the deregulation of private offerings. ${ }^{24}$ Regulatory changes have made it possible for venture capitalists to raise large amounts of money from investors. A series of legal and regulatory changes beginning in the 1970s "gradually allowed pension funds to invest in stocks and higher-risk financial instruments ... and created a large market for unregulated investment instruments". ${ }^{25}$ The National Securities Markets Improvement Act (NSMIA) of 1996 made it easier to set up large pools of private investors by increasing the scope of the federal regulatory regime (section 4.5). ${ }^{26}$

19 See OECD (2019a).

20 Coyle JF, Green JM (2014) pp 158-159.

21 Blockchain Luxembourg S.A. website on 31 July 2019: "Backed by the Best - We've raised \$70M from the leading investors in Silicon Valley, Wall Street, and London.”

22 For the perceived benefits of ICO funding for a blockchain startup (other than Blockchain Luxembourg S.A.), see OECD (2019b) and Boreiko D, Ferrarini G, Giuduci P (2019) p 673.

23 See, for example, Salmon F (2014).

24 See de Fontenay E (2017).

25 Lafer G (2017) p 18. Citing Appelbaum E, Batt R (2014) pp 27-29.

26 Section 102(a) of the National Securities Markets Improvement Act of 1996, amending section 18 of the Securities Act of 1933. Ewens M, Farre-Mensa J (2020): "Among the 'covered securities' that NSMIA exempts from complying with state blue sky laws are those sold under Rule 506 of Regulation D, which allows private issuers to raise unlimited amounts of capital as long as all investors are 'accredited investors.' ... Rule 506 is the most popular exemption used by VC-backed startups to avoid SEC registration.” 
While most young firms seeking $\$ 150$ million or more in the 1990 s had to raise funding through IPOs, such sums could after the regulatory changes be raised privately. Changes in the scope of the federal regulatory regime resulted in a large increase in venture capital business ${ }^{27}$ and kept successful firms private: "The new equilibrium in the entrepreneurial finance market implies that an increasing number of the largest and most successful firms in the U.S. economy are private and so avoid much of the scrutiny and governance regulation imposed on their public peers ... It also implies that ordinary stock-market investors-particularly those that invest via index funds-do not hold in their portfolios an increasing number of the fastest growing firms ..."28

The ancillary services of venture capitalists. Venture capitalists can provide more than just cash. From the perspective of the firm, they provide important ancillary services such as know-how, access to technology or markets, management services, and signalling services.

Venture capitalists can be specialist firms (managers of other people's money) or divisions of non-financial firms (corporate venture capital). ${ }^{29}$ Corporate venture capital can enable a large non-financial firm to protect and build its main business. ${ }^{30}$ Through corporate venture capital, it can track competing technologies, ensure that no competitors with disruptive technologies will emerge, invest in research and development, or spend assets that it otherwise would need to distribute to shareholders. ${ }^{31}$

27 Ewens M, Farre-Mensa J (2020); The Economist, Buttonwood: A private function, 29 September 2018; Doidge C, Kahle KM, Karolyi GA (2018) p 14: "It is often argued that firms do not want to be public because of regulations such as the Sarbanes-Oxley Act of 2002, Regulation Fair Disclosure (Reg FD), and other restrictions imposed on firms and the financial services community in the early 2000s. The biggest problem with this argument is that the peak for listings was in 1997, well before Sarbanes-Oxley and these other major regulatory events. If any regulatory actions played a role in the decrease in listings in the 1990s, it was the deregulatory action that increased the number of investors beyond which a firm has to register its securities. In other words, this deregulation made it easier for firms to raise funds while staying private. Further deregulatory actions took place after the 1990s."

28 Ewens M, Farre-Mensa J (2020).

29 Gilson RJ (2003); Colombo MG, Cumming DJ, Vismara S (2016).

30 The Economist, Corporate venture capital. If you can’t beat them, buy them. Fear of being displaced by startups is turning firms into venture capitalists, 22 November 2014.

31 The Economist, Pharmaceutical M\&A. Invent it, swap it or buy it. Why constant dealmaking among drugmakers is inevitable, 15 November 2014. 
Higher valuations in trade sales. If a company has good prospects and its shareholders want to maximise share price in an exit, the shareholders will prefer a trade sale to an IPO. A trade sale brings a higher valuation. Most venture capital exits are sales to a larger company rather than IPOs. ${ }^{32}$

Generally, a large buyer in the same industry may be able to pay a higher price because of complementarities. Complementarities are more and more important in digital economy. ${ }^{33}$ Since capital market investors cannot create complementarities, complementarities are not created in an IPO. With superior knowledge, trade sale buyers may also be able to assess the target firm's commercial potential better. ${ }^{34}$

The concentration of economy. The globalisation of business has increased the size of large firms. A larger firm can benefit from economies of scale in a global marketplace. Economy is increasingly concentrated.

At the same time, the profitability of small independent firms has declined relative to the value created as part of a larger organisation. A large diversified firm can quickly implement new technology and benefit from economies of scope. ${ }^{35}$

The mechanisms of digital economy have increased both venture capital investments and trade sale exits with large global firms as buyers. Large firm size is vital to create positive network effects in the-winner-takes-all markets.

In the exit and takeover market, the increased transparency of business in a global marketplace has given firms a better idea of where targets and buyers are. The growing minimum size of successful firms, improved access to targets and

32 Ibrahim DM (2013) pp 257-259: "With IPOs now more scarce, the trade-sale exit (being acquired by a larger company in the same industry) becomes the start-up's most promising exit opportunity."

33 Doidge C, Kahle KM, Karolyi GA (2018) p 15: "Some financial economists also argue that economies of scope have become more important and that firms have a shorter window to take advantage of them because of the widening threat of greater competition. If this is true, firms may be better off being acquired by a larger firm rather than accessing the public markets to raise capital. The role of economies of scope is closely tied in to the importance of intangible capital. One key fact is that intangible assets are scalable in a way that tangible assets are not ... [A] firm with a new software tool can increase its sales of that tool at a marginal cost that is close to zero. Hence, its main concern is to sell as much of that tool as possible until it is replaced by a better tool. Having access to a platform with broader visibility and distribution ability would be valuable to such a firm." See also Hanna Murphy, Window shopping to be core part of Instagram's future. Financial Times, 25 June 2019: "Some balked when Facebook paid \$1bn for a 12-person lossmaking and revenue-free Instagram in 2012, but the app has proven a huge hit among younger users and could now be worth $\$ 158 \mathrm{bn}$, according to analysts ...

34 Salmon F (2014).

35 Gao X, Ritter JR, Zhu Z (2013). 
buyers, and higher valuations in trade sale exits may reduce the number of listed firms.

Private equity. Mature companies have been taken over by private equity funds. Private equity funds can pay high prices because of financial engineering.

Because of the threat posed by private equity funds, listed companies have incentives to use various kinds of takeover defences. ${ }^{36}$ They increase the cost of having shareholders. For example, listed companies need a more concentrated share ownership structure or a very large size, a high leverage, and a high share price. To achieve this, they may need to focus on the core business, divest assets to become asset-light, distribute assets to shareholders in the form of dividends and share buybacks, cut costs, increase debts, and grow through takeovers. ${ }^{37}$

The costs of IPOs and regulatory compliance. The overall costs of IPOs and regulatory compliance are high. Firms are more likely to choose an IPO where the benefits outweigh the costs and less likely to do so when the costs are perceived as too high. ${ }^{38}$ The current regulation of stock exchanges and listed firms seems to have benefited stock exchange owners, traders, and institutional investors to the detriment of firms and the market. ${ }^{39}$

There seems to be a conflict between the high cost of regulatory compliance and the institutionalisation of equity investment. When equity investments are institutionalised and indirect, retail investors are not expected to trade directly and are protected in their dealings with financial intermediaries. Institutional and sophisticated investors that do trade directly need less protection because of their greater professionalism and diversified portfolios. Moreover, the risk exposure of fund management companies is limited since they obtain income from the fund. If the purpose of the regulation of IPOs and listed companies really were investor protection, the institutionalisation of equity investment could be

36 See Mäntysaari P (2010a) section 9.2.6, pp 217-220; Mäntysaari P (2010c) Chapter 18.

37 See also Michael Skapinger, Opinion Capitalism. The shareholder-first corporate model erodes public support. Financial Times, 6 March 2017. The Economist, Bad recipe, 2 March 2019: “... Kraft Heinz is a super-sized version of the strategy of much of corporate America over the past decade. Although sales have been sluggish, $66 \%$ of firms in the S\&P 500 index have raised their margins and $68 \%$ have raised their leverage since 2008. A mania for deals in mature industries, premised on debt and austerity, is in full swing." See nevertheless Asness C, Hazelkorn T, Richardson S (2018) on the benefits of buybacks and buyback myths.

38 Nicole Bullock, The reasons for a stagnating US public equity listings market. Financial Times, 17 May 2017.

39 See also Macey JR, O’Hara M (2005) pp 581-582: “... rules that benefit the exchange as a firm may well be to the detriment of the market." 
expected to have resulted in lower-cost regulatory compliance obligations. ${ }^{40}$ Since this has not happened, the question is to what extent market regulation is over-regulation designed to benefit financial intermediaries at the cost of issuer-firms.

The quality of shareholders in public markets. Finally, shareholders in public markets may not be good enough. Shareholders can be a source of funding but are always providers of ancillary services. The services of institutional investors that dominate public markets may be of low quality or too costly for small-cap issuers. Many institutional investors such as private equity funds or hedge funds look for short-term benefits. Many are not interested in small-cap or mid-cap issuers in the first place. The trend of passive investing favours largecap stocks. Low-cost index funds tend to track big companies with liquid shares rather than small companies with inherently illiquid shares. This makes smallcap stocks less interesting even for the remaining active investors in public markets. $^{41}$

Conclusion. There is a long list of reasons that may have contributed to low IPO levels. Firms remain or go private for a combination of reasons that create a powerful market trend against IPOs.

Radical innovation is needed to increase the number of companies with publicly-traded shares and retail investors' direct share ownership. Innovation in company and securities law is not enough but needs to be complemented by "structural changes that focus more on the overall market environment for smaller companies. Put another way, the primary issue is not how to get companies to market, which may merely create a false supply, but how to create a regulatory and market environment that fosters growth in small companies."42

40 Armour J, Bengtzen M, Enriques L (2018) p 400: "This implies that the quality of the legal regime under which issuers operate becomes less important, as institutions are better able to do their own due diligence and insist on appropriate protections."

41 See even The Economist, Privacy and its limits, 1 February 2020: "Right now almost everyone believes that private markets are better than public ones ... Institutional investors are rushing headlong onto private markets, especially into venture capital, private equity and private debt." 42 Rose P, Solomon SD (2016) p 127. 


\subsection{Practices of Angel Investors, Venture Capital Firms and Investment Funds}

\subsubsection{General Remarks}

IPO levels have been influenced by angel funding and venture capital practices. Angel funding and venture capital were to a large extent developed in California ${ }^{43}$ and are closely connected to the unique culture of Silicon Valley. ${ }^{44}$

These forms of corporate finance used to lead to an IPO as the textbook model of exit and entrepreneurial success. But market practices have changed. Start-up funding practices now tend to lead to a trade sale rather than an IPO. For example, the IPO of Tesla Motors in 2010 still reflected the traditional Silicon Valley model. In August 2018, Elon Musk regretted Tesla's IPO and unsuccessfully proposed taking the company private. But Tesla remained a public company. Tesla and many other public tech companies reached very high market valuations in $2020 .^{45}$ The scarcity of tech company stocks and very high valuations increased tech company IPOs in $2020 .{ }^{46}$

There are different forms of funding for different stages in the life of the firm. Investors are specialised. It is therefore necessary to address transition from one form of funding to the next (section 5.3.3). Moreover, the governance of many start-ups or growth firms is adapted to the preferences and practices of venture capital firms and angel investors (section 5.3.4). The governance of start-ups or growth firms is a particular form of the corporate governance of closely-held companies that generally has been "neglected for far too long" in corporate governance research. ${ }^{47}$ As regards the role of fund investors, venture capital firms

43 Gompers PA, Lerner J (2001) p 149: "When venture capital disbursements are divided by industry, about 60 percent in 1999 went to information technology industries, especially communications and networking, software, and information services ... When venture capital disbursements are viewed geographically, a little more than one-third of venture capital went to California. A little less than one-third went to Massachusetts, Texas, New York, New Jersey, Colorado, Pennsylvania, and Illinois, combined."

44 See Lee CM, Miller WF, Hancock MG, Rowen HS (eds) (2000); Suchman MC, Cahill ML (1996); Coyle JF, Green JM (2017).

45 See Richard Waters, Patrick McGee, Hannah Murphy, Big Tech defies global economic fallout with blockbuster earnings. Financial Times, 31 July 2020; Michael Mackenzie, Why big tech stocks can weather the storm. Financial Times, 12 September 2020; Richard Henderson, Eric Platt, Tesla reversal tests faith in Elon Musk's 'business miracle'. Financial Times, 11 September 2020.

46 See The Economist, Partying like it’s 1999, 22 August 2020.

47 Fleischer H (2018e) p 680. 
apply the same basic practices as the operators of investment funds in general. There is separation of capital investment, share ownership, and control. Fund investors have no rights in portfolio companies and their control rights are very limited in the fund (section 5.3.2).

\subsubsection{Separation of Capital Investment and Control}

The practice of investment funds such as hedge funds, private equity funds, or venture capital funds builds on the separation of capital investment, corporate share ownership, and control. ${ }^{48}$ Fund investors generally are even more passive than the passive shareholders of publicly-traded companies. ${ }^{49}$

A fund investor owns shares in an investment fund. A fund investor does not become shareholder in the management company of the fund or any of the companies in the fund's portfolio. Fund investors therefore have no role to play in the governance of the management company and portfolio companies. ${ }^{50}$ Moreover, their control rights tend to be radically limited in the fund. The default rule is that the fund management company is neither shareholder in a portfolio company nor a fund investor. Sometimes the management company or its executives do invest in the fund or portfolio companies, but in practice the management company can control one or more funds and use voice in the funds' portfolio companies without any capital investment. One can therefore say that market investors that choose indirect equity investments by putting their money in funds waive all their control rights in portfolio companies. If a fund exercises control in a portfolio company, its powers can be used by the representatives of the fund's management company or by an external service provider.

Venture capital has its own particular characteristics. In traditional venture capital practice, power in a portfolio company is allocated to company founders and managers of venture capital. In effect, this practice means two things in relation to the separation of powers. In a way, it means a return to practices that

48 Gilson RJ (2003) on venture capital. Morley J (2014) and Ferrell A, Morley JD (2018) on investment funds.

49 See Ferrell A, Morley JD (2018) p 333 on mutual fund shareholders in particular: "Mutual fund shareholders thus exhibit an extreme of passivity that exceeds even the much discussed passivity of ordinary public company investors. In an ordinary public company, small and unsophisticated investors tend to find it rational not to vote. But in a mutual fund, even the large and sophisticated investors will fail to vote, because they will always find it easier instead to redeem."

50 See Morley J (2014) p 1241. 
preceded the separation of powers and the shielding of management against shareholders (section 2.4.2). Moreover, it means that the representatives of the venture capital firm can have control rights in the portfolio company without a corresponding equity investment.

This practice may benefit the start-up or growth firm. On one hand, the survival of a start-up or growth firm depends on the quality of its founders, managers, and employee shareholders. They can provide important services as shareholders. ${ }^{51}$ On the other, a successful growth firm customarily needs venture capital. In addition to access to equity capital from the fund that they manage, the managers of the venture capital firm (venture capitalists) can provide ancillary services that are regarded as important for the survival of the firm.

The allocation of control rights in the portfolio company to the venture capital firm or its managers can be explained by three things. The first relates to the function of venture capitalists as gate-keepers of funding and providers of ancillary services. The agreed governance model of the firm is designed to enable venture capitalists to provide those ancillary services. The second relates to the terms of the fund. The venture capital firm or its managers can ensure compliance with the terms of the fund by being in control of the portfolio company. The third relates to the bargaining power of venture capitalists. To understand the actual allocation of power, it is not enough to refer to the efficiency of control arrangements ${ }^{52}$ or to uncertainty and information asymmetries between principals and agents. ${ }^{53}$ Start-ups and growth firms often need venture capital and may have few alternatives.

A venture capital contract thus allocates power to venture capitalists. In the portfolio company, this is achieved by the staging of funding, board representation, negative covenants, and provisions on exit.

It has been said that " $[\mathrm{t}]$ he venture capital fund-portfolio company contract stands the Berle-Means problem on its head. Instead of investors having disproportionately more equity than control as in public corporations, the venture capital fund has disproportionately more control than equity." 54

This is not the whole picture. Since the contractual framework allocates power in particular to the general partner or managers of the venture capital

51 See, for example, Gilson RJ (2003) p 1083; Hill J (2021) section 2.1 p 20.

52 See Morley J (2014) on the efficiency of control in investment funds.

53 Sahlman WA (1990) p 473: "The venture-capital industry has evolved operating procedures and contracting practises that are well adapted to environments characterized by uncertainty and information asymmetries between principals and agents.”

54 Gilson RJ (2003) pp 1081-1082. 
fund, ${ }^{55}$ fund investors are effectively excluded from the governance of portfolio companies and fund managers have much more control than equity. Since fund managers use the fund as leverage, they can exercise control without equity in portfolio companies.

Many large and small financial investors have traded their control rights for exit rights in highly popular investment fund practice. This can make sense for both investors and portfolio companies since shareholders generally have not provided good control services in the past (section 2.4.5) and specialised professionals can provide better services. ${ }^{56}$

\subsubsection{Different Investors for Different Stages of Development}

There are different forms of funding for different stages of development. Investors are specialised. For this reason, it is necessary to address transition from one form of funding to the next.

Specialised investors. The funding of new growth companies has been the business of specialised investors. They are "specialised by stage of development (i.e. start-up, product development, revenue generation, or profitability stage) or by round (i.e. seed, first, second, or later round)". ${ }^{57}$

Angel investors ${ }^{58}$ and crowd investors ${ }^{59}$ can be sources of seed funding. Funding needs tend to increase as the firm grows. The later the round, the greater the funding invested in a round. Venture capital is for later funding rounds when the firm has larger funding needs. Venture capital traditionally has not been available for seed funding. For example, the first Vision Fund that made big

55 Ibid., p 1071: "The general partner (GP) puts up only one percent of the capital, but receives essentially complete control over all of it. The particular terms of the fund's governance are set out in the limited partnership agreement."

56 Morley J (2014) pp 1245 and 1248: "[M]ost fund investors have unusually strong exit rights and most fund managers have unusually strong performance incentives. Both of these features take the place of control, and as a consequence control over management companies resides more efficiently in the hands of management company investors than in the hands of fund investors. Fund investors thus benefit from the limits on control, because the placement of control in the hands of its most efficient users allows investment funds to offer lower fees and better returns ... As a result of exit and withdrawal rights in investment funds, fund investors value control rights less than ordinary company investors do. Fund investors do not value control, because if they are unhappy, they can simply remove their money and take it elsewhere."

57 OECD (2015c) p 110.

58 Ibrahim DM (2008); Wong A, Bhatia M, Freeman Z (2009).

59 OECD (2015c) p 82. 
bets needed to invest at least $\$ 100$ million per deal as part of an agreement with its investors. ${ }^{60}$

The role played by these specialised investors in the US has been summed up as follows: "The conventional wisdom is that entrepreneurs seek financing for their high-growth, high-risk start-up companies in a particular order. They begin with friends, family, and 'bootstrapping' (e.g., credit card debt). Next they turn to angel investors, or accredited investors (and usually ex-entrepreneurs) who invest their own money in multiple, early-stage start-ups. Finally, after angel funds run dry, entrepreneurs seek funding from venture capitalists (VCs), whose deep pockets and connections lead the start-up to an initial public offering (IPO) or sale to a larger company in the same industry (trade sale)."61

Both in Europe and the US, the greatest portion of new growth company funding supports later stage ventures, "when companies are perceived to be partially de-risked and close to their revenue generation stage". ${ }^{62}$ In contrast, seed and early stage financing play a bigger role for investors in Israel, ${ }^{63}$ a country with a tight community and a very successful tech sector. ${ }^{64}$

Crowdfunding is a relatively new source of seed funding (Chapter 7). It promises more diverse funding options, allows new companies to grow at a quicker pace, and shortens the time between early funding stages. ${ }^{65}$ It is customary to distinguish between five models of crowdfunding: donations-based, rewardsbased, pre-selling or pre-ordering-based, lending-based (P2P), and equitybased crowdfunding. ${ }^{66}$

Of the five models of crowdfunding, only equity-based crowdfunding enables investors to participate in the company's long-term value creation. ${ }^{67} \mathrm{Howev}$ er, the shares subscribed for at this stage tend to lack both underwriters and a secondary market. ${ }^{68}$ Equity crowdfunding is also constrained by securities laws. ${ }^{69}$ In the US, equity crowdfunding was not permitted until the Securities

60 Miles Kruppa, SoftBank's second Vision Fund speeds up pace of investment. Financial Times, 11 July 2021.

61 Ibrahim DM (2013) p 251.

62 OECD (2015c) p 113.

63 Ibid.

64 Senor D, Singer S (2011); Morrison \& Foerster LLP (2017) p 6.

65 World Economic Forum (2015) p 18.

66 OECD (2015c) pp 82-82; UNDP (2018) p 113; UNDP (2017).

67 See Heminway JM (2017) pp 193-195.

68 See, for example, Unleashing the potential of Crowdfunding in the European Union. Communication from the Commission, $\operatorname{COM}(2014) 172$ final.

69 See Heminway JM (2017) p 195: "Equity crowdfunding, as a financing method involving the offer and sale of securities, engages securities regulation. Specifically, in the United States, 
Act of 1933 was amended by the JOBS Act of $2012 .^{70}$ Depending on the country, securities laws may restrict equity investments to professional investors.

Transition. Since the funding of start-ups and growth firms is staged, there must be a transition. If there are different kinds of investors for different stages of the firm's development, there is a transition from one source of funding to another. For example, there can be a transition from venture capital funding to public market funding, from angel funding to venture capital funding, or from crowdfunding to angel or venture capital funding. ${ }^{71}$

Later-stage investors have preferences relating to the management of risks, agency relationships, and information. Where later-stage funding is hampered by early-stage funding contracts, later-stage funding may not happen. Without later-stage funding, the business project will fail. This means that there are constraints on what early-stage investors can do. ${ }^{72}$ Start-up and early-stage investors may need to align their preferences with the preferences of later-stage investors and ensure that there is contractual compatibility between their early-stage funding contracts and later-stage investors' contracts.

Moedl has therefore called for "a better understanding of contractual interdependencies between sequential financing sources"73 and pointed out that the requirements of later-stage venture capital may dictate whether early-stage crowdfunding is suitable for start-ups. ${ }^{74}$

According to anecdotal evidence, access to later-stage funding is a bigger problem in Europe than in the US. ${ }^{75}$

under the Securities Act of 1933, ... absent an exemption, an issuer must register the offer and sale of investment instruments categorized as securities."

70 See, for example, Williamson JJ (2013) p 2074.

71 See Wroldsen JS (2013) pp 615-616.

72 Moedl M (2019); Gilson RJ (2003); Heminway JM (2017) pp 209-211. Uncertainty, information asymmetry, and agency costs "inevitably bedevil early-stage, high-technology financing” according to Gilson.

73 Moedl M (2019) p 3 on the funding case of Smarchive.

74 Ibid., p 2.

75 Jonathan Guthrie, Opinion. Entrepreneurship. Why full 'network effect' evades Europe's start-ups. Financial Times, 23 March 2020: "In Europe, the historic problem has been that start-ups lack follow-on funding, let alone public market investors willing to bear years of losses as companies scale up." 


\subsubsection{The Preferences of Venture Capital Firms and Angel Investors}

In closely-held companies, it is customary for shareholders to agree on voting rights, share transfer restrictions, exit rights, the composition of the board, and the remuneration of board members. ${ }^{76}$ Angel investors and venture capital investors tend to have their own characteristic preferences. ${ }^{77}$ There are largescale studies on venture capital contract practices. ${ }^{78}$ Generally, venture capital contracts shift risk from the investor to the entrepreneur. ${ }^{79}$ Angel investment practices have gradually been influenced by venture capital practices.

In addition to capital (angel investors) or access to fund capital (managers of venture capital funds), angel investors and venture capitalists provide valuable ancillary services. For example, they may help to develop the idea, secure future financing, organise management, professionalise the firm, or bring the product to the market. ${ }^{80}$ Moreover, the participation of angel investors and venture capital firms can signal the good quality of the investment. ${ }^{81}$ The agreed terms of angel funding and venture capital funding reflect the ancillary services provided by angel investors and venture capitalists.

The preferences of venture capital investors. Venture capital investors can use various kinds of securities such as common stock, preferred stock, and convertible instruments. ${ }^{82}$ In US venture capital practice, investors tend to require convertible preferred stock. ${ }^{83}$ Venture capital is disbursed to the target company in stages over several investment rounds. ${ }^{84}$

76 Fleischer H (2018e) p 691.

77 For legal innovation in this context, see Coyle JF, Green JM (2014).

78 Kaplan SN, Strömberg P (2001); Kaplan SN, Strömberg P (2003); Kaplan SN, Strömberg P (2004); Denis DJ (2004); Da Rin M, Hellmann T, Puri M (2013); Gompers PA, Gornall W, Kaplan SN, Strebulaev IA (2016).

79 See Moedl M (2019) pp 7-8 summing up earlier large-scale studies.

80 See OECD (2015c) pp 110 and 119-120; Gilson RJ (2003); Ibrahim DM (2008) p 1411; Wong A, Bhatia M, Freeman Z (2009) p 228.

81 See, for example, Lee PM, Pollock TG, Jin K (2011).

82 See Coyle JF, Green JM (2014) pp 146-148: “In 1981, the Practicing Law Institute published a book entitled The Legal Aspects of Venture Capital Investing. This book listed a number of different types of securities that were widely used in venture finance, including (1) common stock, (2) convertible preferred stock, and (3) convertible notes or debentures." In Chinese venture capital practice, a functional alternative to convertible preferred stock is the valuation adjustment mechanism (VAM). See Lin L (2020).

83 Ibrahim DM (2008) p 1413; Coyle JF, Green JM (2014) pp 149-150; Ewens M, Gorbenko AS, Korteweg A (2019).

84 Gilson RJ (2003) p 1078; Ibrahim DM (2008) p 1413; Coyle JF, Green JM (2014) p 150. 
The contractual and corporate framework is influenced by the large size of venture capital investments and the practices of fund management. Control rights depend on the size of the share block. ${ }^{85}$ Venture capitalists prefer to control decision-making in portfolio companies by controlling the board. ${ }^{86}$ The use of convertible instruments enables venture capitalists to reduce their risk exposure and benefit from an increase in the valuation of the company. ${ }^{87}$ For the same reasons, venture capital contracts include negative covenants ${ }^{88}$ and provisions on exit. ${ }^{89}$ Venture capital contracts can provide for price-based anti-dilution protection, shares-based anti-dilution protection, tag-along rights (or cosale rights), and pre-emptive rights. ${ }^{90}$ The choice of the legal form of the portfolio company can depend on the interests of fund investors. In US venture capital practice, it is customary to choose between the LLC and the C Corp. ${ }^{91}$

When venture capitalists get convertible preferred stock, the valuation of the company plays a major role. A high valuation of the company at the time of investment means in practice that venture capitalists will have a right to convert their convertible securities into a large block of shares at the time of exit. Since the convertible securities are preferred, the company should even have a high valuation before common stockholders are paid in the event of liquidation. If the combined effect of the use of convertible preferred stock and a high valuation is in the interests of venture capitalists, ${ }^{92}$ it could be a driver of higher valuations.

The preferences of angel investors at the end of the twentieth century. Angel investment is different. Angel investment practices have been influenced by the high-risk nature of start-up investments, the potential or anticipated availa-

85 Ewens M, Gorbenko AS, Korteweg A (2019): "We find that contracts materially affect startup values, with both value-increasing and decreasing components. Fixing the quality of investor and entrepreneur, the average startup's value increases with the investor's equity share up to an ownership stake (upon conversion) of $15 \%$." For block-holding as a corporate governance tool, see Mäntysaari (2010a) sections 9.4.2 (controlling shareholders) and 9.5.5 (minority shareholders).

86 Gilson RJ (2003) pp 1081-1082; Ibrahim DM (2008) pp 1414-1415.

87 The Economist, Schumpeter. The entrepreneur's new clothes, 28 September 2019: "Governance remains dull as ditchwater in Silicon Valley-until something goes wrong."

88 Gilson RJ (2003) p 1082; Ibrahim DM (2008) p 1415.

89 Gilson RJ (2003) pp 1084 and 1091; Ibrahim DM (2008) p 1415.

90 See Wroldsen JS (2013) pp 615-622 and pp 629-631.

91 Fleischer V (2003-2004); Ibrahim DM (2013) pp 263-264. The C Corp is a business organised under Subchapter C of the Internal Revenue Code.

92 The Economist, Buttonwood. Stacked and whacked, 11 April 2020. 
bility of venture capital in later funding rounds, and by technological advancement.

There is a high failure rate. An angel investor may invest in many start-ups, but "an angel investor's financial payoff comes from a small number of start-ups that go on to attract venture capital and then exit by an [IPO] or private sale". ${ }^{93}$

In the past, the high failure rate of angel investments and the relatively high cost of starting a business were reflected in the small size of angel investments. Each angel investor allocated relatively small amounts of funding to a relatively large number of start-ups. Coyle and Green have summed up the practices as follows: "Venture finance, as it was practiced in Silicon Valley and elsewhere at the turn of the last century, operated within a fairly stable legal framework. In a company's early days, friends, family, and angel investors would contribute relatively small amounts of capital to the venture in exchange for common stock. As the company grew, its founders would raise additional capital from VCs by issuing convertible preferred stock. In the event that future rounds of financing were required, the company would sometimes issue convertible notes to its existing investors in order to obtain enough capital to sustain it until the next preferred stock round of financing or a sale." 94

The high failure rate and small size of investments as well as the anticipation of next funding rounds kept contract practices simple. It would have been too costly to "design, write, monitor, and enforce detailed contracts when smaller dollar amounts are invested". ${ }^{95}$ For each high-net-worth individual providing angel funding, such a small investment was "not much more than a lottery ticket”. ${ }^{96}$

It was, therefore, customary for angel investors to receive common stock. Angel investors did not stage investments. ${ }^{97}$ Angel contracts customarily did not provide for any specific exit rights. ${ }^{98}$ This simplified the legal framework and reduced legal fees. ${ }^{99}$

Neither did angel investors require board seats. ${ }^{100}$ Instead, angel investors preferred "informal methods of screening and monitoring entrepreneurs". ${ }^{101}$

\footnotetext{
93 Ibrahim DM (2008) p 1408.

94 Coyle JF, Green JM (2014) pp 154-155.

95 Ibrahim DM (2008) p 1408.

96 See Coyle JF, Green JM (2014) pp 148 and 159.

97 Ibrahim DM (2008) pp 1422-1423; Coyle JF, Green JM (2014) pp 146-148.

98 Ibrahim DM (2008) pp 1422-1423.

99 Coyle JF, Green JM (2014) pp 147 and 159.

100 Ibrahim DM (2008) pp 1422-1423.

101 Ibid., p 1408.
} 
Generally, angel contracts left more discretion to founders. Angel investors used "more entrepreneur-friendly terms than do venture capitalists". Angel investors customarily did not use restrictive contract terms such as negative covenants that allow investors to veto management decisions. ${ }^{102}$ Such contract terms would have "reduce[d] their chances for a large upside by making follow-on venture capital funding unlikely". ${ }^{103}$ In other words, the lure of venture capital at a later stage weighed more than the high risk of early investment. Venture capitalists wanted to standardise their processes and keep negotiations uncomplicated. It was easy for them to turn down investment proposals in which angel investors already had taken their place. ${ }^{104}$

The preferences of angel investors in the twenty-first century. In the twentyfirst century, the digital revolution made it easier to start a business: "In summary, a confluence of developments in technology - including cloud-based servers, cloud-based software, and open-source code - substantially reduced the costs of launching a technology-based start-up, beginning in approximately 2005. At the same time, a number of other factors-including the improved accessibility of high-speed Internet and the increased popularity of social media-enabled these same companies to rapidly achieve significant scale.”105

Technological advancement and the reduced costs of starting a business influenced the practices of angel investors. They increased the size of angel investments, changed contract practices, and influenced angel investors' ancillary services. ${ }^{106}$ An angel that makes a larger investment in a start-up has more powerful incentives to monitor the start-up. ${ }^{107}$ Accelerator companies have emerged as early investors that provide intensive mentorship. ${ }^{108}$

102 Ibid., pp 1422-1423.

103 Ibid., p 1408.

104 Ibrahim DM (2013) pp 255-256: "Because this negotiation and unwinding is costly and time-intensive, VCs considering numerous investment candidates may pass on these particular start-ups.”

105 Coyle JF, Green JM (2014) p 157. See also Ibrahim DM (2013) pp 251-252 and 256-257.

106 Ibrahim DM (2013) pp 251-252.

107 Coyle JF, Green JM (2014) p 159.

108 Hoffman DL, Radojevich-Kelley N (2012) p 58: "In exchange for funding, accelerator companies take a 5 percent to 6 percent equity stake of their participating boot-camp venture. Most of the accelerator companies state that they have no interest in controlling the nascent firm. Virtually all of the accelerators require a small portion of equity with an increased equity requirement for additional angel or VC rounds of funding ... Accelerators provide value to their participants with early stage funding and, equally important, intensive mentorship. While the average start-up needs early stage funding, it is not a massive amount of capital ...” Kenney M, Zysman J (2019): "Their goal was to assist in the growth of the entrepreneurs' idea to the point that they 
In recent US start-up funding practice, it has become more common for early-stage angel investors to purchase convertible notes. ${ }^{109}$ This practice became popular after approximately 2005. ${ }^{110}$

Historically, the primary venture-finance purpose of the convertible note was to serve as a "bridge" between one round of venture financing and the next. ${ }^{111}$ Coyle and Green describe the thinking behind convertible notes as follows: "Despite its debt-like features, such as interest rates, maturity dates, and security interests, bridge notes could also be thought of as a deferred equity investment because the bridge investors' expectations were not to have the principal repaid with interest, but to receive equity at some future date."112

In start-up financing, off-the-shelf bridge note documentation was used as a model in the seed context. Over time, this instrument was adapted to seed funding. For example, to simplify documentation, investors were promised a straightforward discount to the actual price in the next equity financing round. Security interests were deleted, because a seed-stage company customarily had no meaningful assets to serve as collateral.

These changes brought benefits to both investors and founders. First, should the start-up fail, the note was a debt instrument. In this case, the noteholder was protected better than a shareholder. Second, should the start-up succeed in attracting additional investment, the investor could convert the note into the same security that the first institutional VC investors would receive. Third, the simplicity of the instrument kept legal fees lower. Fourth, the parties could defer the valuation of the company to the later stage investor. ${ }^{113}$

There were some disadvantages. For the founder and the start-up, there was a risk of extend-or-pay claims. Where the note matures before a conversion event, the debt must be repaid unless the noteholder agrees to grant an extension. Since the start-up cannot repay the debt, the noteholder may force the founder and the company to grant better terms. For the noteholder, there are risks caused by the absence of a fiduciary duty. The investor is not a shareholder but is treated as a contract party. The terms of the contract, therefore, are the main source of protection to the noteholder. ${ }^{114}$

could 'graduate' and form a proto-firm, able to raise money from angel groups or venture capitalists ..."

109 Green JM, Coyle JF (2016) p 171.

110 Coyle JF, Green JM (2014) p 148.

111 Ibid., p 151.

112 Ibid., p 153.

113 Ibid., pp 161-162.

114 Ibid., pp 162-163. 
At the end of 2013, the Simple Agreement for Future Equity (SAFE) emerged as a new startup-financing tool. The SAFE was developed by Y Combinator as a means of investing in start-ups that expected to raise institutional venture capital at a later date. Y Combinator took the basic convertible note and stripped the debt attributes out of it. This made the SAFE a simple contractual derivative instrument. It is neither debt nor equity. It will prove valuable to the holder if, and only if, the company that issues it raises a subsequent round of financing, is sold, or goes public. 500 Startups, another leading entrepreneurship accelerator, developed the Keep It Simple Security (KISS). KISS is a short version of a convertible debt contract. ${ }^{115}$

Syndication. Venture capital investments tend to be much larger than angel investments. This is reflected in the use of a more detailed process and more detailed contracts in venture capital. ${ }^{116}$

The small size of each angel investment can lead to free-riding as angel investors seek to benefit from the work of other angel investors. Angel investors can share the work by syndication. ${ }^{117}$ By syndicating investments, angel investors can screen and pool investments as a group. For example, there can be regional angel groups. ${ }^{118}$ The greater size of pooled investments can influence contract terms as well.

In the US, Title II of the JOBS Act made it easier for accredited investors to invest in early-stage ventures through syndicates where lead investors bring deals to a crowd of backers. ${ }^{119}$ Title II has been a success. ${ }^{120}$

Staging and participation in subsequent funding rounds. In economics, some goods are regarded as credence goods the quality of which cannot be verified ex ante. ${ }^{121}$ There are similar issues in the funding of start-ups and growth firms.

To manage this problem, venture capital investors customarily use the staging of investments as a control mechanism: ${ }^{122}$ "Instead of providing the entirety of capital in a lump sum, the investment is allocated by stages, preserving the investor's option to abandon." 123 Investors agree to put in more money provided

115 Ibid., pp 168-171; Green JM, Coyle JF (2016) pp 171-172.

116 Ibrahim DM (2008) p 1408.

117 Wong A, Bhatia M, Freeman Z (2009) p 227.

118 Ibrahim DM (2008) p 1409.

119 Catalini C, Fazio C, Murray F (2016) p 9.

120 Ibrahim DM (2015) p 565; Catalini C, Fazio C, Murray F (2016) p 12.

121 See, for example, Mäntysaari P (2010a) p 338.

122 Sahlman WA (1990) p 474; Gilson RJ (2003) p 1078; Ibrahim DM (2008) p 1413.

123 Wong A, Bhatia M, Freeman Z (2009) p 225. 
that the portfolio company meets the agreed milestones. Staging is a powerful governance tool as the firm will have no future without proper funding. ${ }^{124}$

Angel investors traditionally have not used staging. First round investors may nevertheless want to participate in subsequent funding rounds even though they may prefer not to be contractually obligated to do so. ${ }^{125}$ Many angel investment contracts contain a follow-on right of first refusal provision. Such a clause allows angels to participate in future rounds to capture the potential upside in successful ventures. Some angel investment contracts contain a weighted ratchet clause for protection against dilution at decreased valuation in future funding rounds. $^{126}$

Control and multiple classes of shares. It is customary to use multiple classes of shares. The use of multiple classes of shares is part of European company law practice, ${ }^{127}$ US start-up and venture capital practice, ${ }^{128}$ and global stock exchange practice.

In company law practice, founders may prefer to cement their position before agreeing to issue shares to financial investors. The use of multiple voting rights or non-voting shares makes it possible to issue more shares to investors without founders or controlling shareholders losing control. ${ }^{129}$

Preferred stock financing was developed as a financial innovation in Britain and used extensively in Britain and the US by the end of the nineteenth century. It was partly designed to overcome shareholder objections to the issuance of additional stock, which diluted the equity of the original shareholders. ${ }^{130}$

In start-up funding, it is customary for entrepreneurs, employees, friendsand-family investors, and agent investors to subscribe for common stock. ${ }^{131} \mathrm{Mul}$ tiple classes of shares can be used in later funding rounds to protect and reward early high-risk investors when the company turns to lower-risk investors.

124 Gilson RJ (2003) p 1074: "Because a financing round will not provide funds sufficient to complete the portfolio company's business plan, staged financing in effect delegates to the investors, in the form of the decision whether to provide additional financing, the decision whether to continue the company's project.”

125 Ibid., p 1073.

126 Wong A, Bhatia M, Freeman Z (2009) p 226.

127 See, for example, Article 10(1) of Directive 2004/25/EC (Directive on takeover bids); Mäntysaari P (2010a) sections 9.4.2 and 9.5.6. See also Marcus Opp, 'Evidence' is useless on dual-class share structures. From Marcus Opp, Professor of Finance, Stockholm School of Economics, Sweden. Financial Times, 26 March 2019.

128 See, for example, Broughman BJ, Fried JM (2013) pp 1326-1327.

129 See, for example, Hill J (2021) section 2.1 p 20.

130 Baskin JB, Miranti PJ Jr (1997) pp 150-152.

131 Ibid., pp 1326-1327; Ibrahim DM (2008) p 1413. 
Multiple classes of shares are used in venture capital practice. In principle, venture capital investors could subscribe for common stock, preference shares, convertible shares, or convertible loans. In the US, venture capital investors almost always invest through convertible preferred stock. ${ }^{132}$

Moreover, it is customary to use a new class of shares for each venture capital funding round: "Unlike public companies, which generally have a single class of common equity, VC-backed companies typically create a new class of equity every 12 to 24 months when they raise money." ${ }^{33}$ The average unicorn in a sample of 135 American unicorns had eight share classes, where different classes of shares could be held by different shareholder categories. ${ }^{134}$

While some shares may need to be converted into common shares before an IPO, ${ }^{135}$ multiple classes of shares have been used in many tech firm IPOs. ${ }^{136}$ This can be illustrated with the Form S-1 registration statements of Google, Lyft, Facebook, and Snap. (a) Multiple classes of shares were used in the IPO of Google in 2004 to ensure that the founders and key executives remained in control. ${ }^{137}$ (b) The 2019 registration statement of Lyft describes how Lyft used Class A common stock and Class B common stock conferring different rights with respect to voting and conversion. In effect, the two founders of Lyft were to control nearly 50 per cent of the votes with 7 per cent of the common stock. ${ }^{138}$ (c) In the 2012 IPO of Facebook, shares of Class A common stock entitled to one vote per share and shares of Class B common stock to ten votes per share. Mark Zuckerberg, the founder, protected his majority of votes by holding Class B common stock. ${ }^{139}$ (d) Snap had three classes of common stock: Class A, Class B, and Class C. Holders of Class A common stock had no voting rights. Holders of Class B

132 Berlin M (1998) p 21; Bratton WW (2002); Ibrahim DM (2008) p 1413; Broughman BJ, Fried JM (2013) pp 1323 and 1327.

133 Gornall W, Strebulaev IA (2020).

134 Ibid.

135 Broughman BJ, Fried JM (2013) p 1323: “In a trade-sale exit, VCs choose between retaining their preferred shares (and capturing most or all of the proceeds through their liquidation preferences) or converting the preferred shares into common shares. In an IPO, VCs (as a practical matter) must convert to common stock." Ibid., p 1328: "If the VCs exit via an IPO, underwriters will typically insist that the VCs convert their preferred shares to common shares and give up their liquidation preferences along with other rights attached to the preferred stock."

136 See, for example, Brooke Masters, Opinion IPOs. Lyft's IPO shows some shareholders are more equal than others. Multiple class structures have become increasingly popular in the tech sector. Financial Times, 6 March 2019.

137 See "Letter from the Founders" in Google, Inc, S-1 registration statement, 18 August 2004. 138 Lyft, Inc., Form S-1 registration statement, 1 March 2019.

139 Facebook, Inc., Form S-1 registration statement, 1 February 2012. 
common stock were entitled to one vote per share and holders of Class C common stock to ten votes per share. Only Class A non-voting shares were issued to investors in the IPO. In effect, the two founders of the company continued to be able to control the outcome of all matters submitted to stockholders for approval. ${ }^{140}$

According to data collected by Jay Ritter, ${ }^{141}$ structures with multiple classes of shares were rather rare in US IPOs from 1980 to 2014. However, such structures were used in 35 per cent of US tech IPOs between 2014 and 2018.

The Council of Institutional Investors, whose members include mutual fund managers, pension plans, foundations and endowments, has asked US stock exchanges to require "sunset provisions" for all newly-listed companies with dualclass structures. ${ }^{142}$ A sunset provision would move the company to a one share, one vote structure once it has been public for a period of time.

However, SEC rules do not mandate that the rules of a national securities exchange must provide for a "one share, one vote" requirement for listed issuers. ${ }^{143}$ Internationally, the popularity of structures with multiple classes of shares has forced some stock exchanges that have not permitted them in the past to consider introducing them in the future. The London market is no exception. ${ }^{144}$

What one can learn is that maintaining control in the future can be important for founders. The use of multiple classes of shares is one of the ways for founders or controlling shareholders to maintain control. Permitting the use of multiple classes of shares should be regarded as necessary for policy reasons since their absence would hamper the growth of a country's tech industry. ${ }^{145}$

140 Snap Inc., Form S-1 registration statement, 2 February 2017.

141 Initial Public Offerings: Updated Statistics. Jay R. Ritter, Cordell Professor of Finance, University of Florida, December 31, 2018.

142 Website of the Council of Institutional Investors.

143 SEC Release No. 34-85828 (May 10, 2019), III.E.3: “[T]he Commission received one comment letter on LTSE's Form 1 application. In its comment letter, the Council of Institutional Investors ('CII') advised that it could not support LTSE's Form 1 application ... The issues raised in the CII Letter do not provide a basis for the Commission to reject LTSE’s Form 1 application. Commission rules do not mandate that the rules of a national securities exchange must provide for a 'one share, one vote' requirement for listed issuers."

144 Lu L, Ye N (2018) p 530: "At present, the Shanghai and Shenzhen stock exchanges do not permit the dual-class structure and consequently have lost the listing of several tech firms to the New York stock exchange and Nasdaq. Currently, London, Hong Kong and Singapore have been considering introducing dual-class shares as they fear losing their prestigious status as global financial centres, and especially, in terms of attracting IPO business.” Hill J (2021) section 2.1 p 19: "Allow companies with dual class share structures to list in the premium listing segment but maintain high corporate governance standards by applying certain conditions."

145 See Reddy B (2020) on how this question has hampered the growth of tech in the UK. 
Board seats. Board seats are an important form of control. Because of the separation of powers in the company, the company is in the legal sense controlled by its board (section 2.4.5). Legal control complements de facto control by the entrepreneur, the founders, other controlling shareholders, or any other person.

Angel investors customarily do not have board seats ${ }^{146}$ but rely on informal channels to influence the firm. In contrast, venture capitalists want board seats and tend to dominate the board. ${ }^{147}$ According to a study by Wong, insiders had a majority in over $80 \%$ of the boards in the sample of angel-backed firms but comprised the majority in only $13.9 \%$ of the boards in venture-capital-funded firms. ${ }^{148}$

Board seats can give venture capitalists the power to affect corporate decisions and choose the form of exit according to their own preferences. In practice, "independent" board members have incentives to side with the venture capitalists that chose them. ${ }^{149}$ After the venture capital exit, control will change hands and may sometimes return to the entrepreneur. ${ }^{150}$

The allocation of board seats to venture capitalists reflects the fact that their ancillary services are regarded as vital for the success of start-ups and much better than the services of shareholders in general. In the nineteenth century, shareholders turned out to be a poor source of management and monitoring services, which led to the separation of powers in the company (section 2.4.5).

The evolution of venture capital after covid-19. The covid-19 crisis accelerated the evolution of venture capital practices. Traditional venture capital investments are preceded by lengthy negotiations in person and traditional venture capital management firms ask for board seats to control portfolio companies. But due to covid-19, meetings in person were largely replaced by meetings on video-conferencing platforms. This influenced the practices of Tiger Global Management, a New York hedge fund that also invests in private tech firms. Since meetings can be arranged on video-conferencing platforms, dealmaking is faster. Tiger Global does not ask for board seats. Instead, it uses metrics to judge performance. Competition from Tiger Global has forced Californian venture capital management companies to offer more generous terms. Central bank capitalism may have help-

146 Wong A, Bhatia M, Freeman Z (2009) p 226.

147 Ibid., p 224; Broughman BJ, Fried JM (2013) pp 1329 and 1344-1345.

148 Wong A, Bhatia M, Freeman Z (2009) p 225.

149 Ibrahim DM (2008) pp 1414-1415. See also Ibrahim DM (2013) p 262.

150 Bratton WW (2002) pp 897-898. 
ed, because there is plenty of money that must be invested somewhere. SoftBank has altered its practices as well. ${ }^{151}$

Lock-in clauses. Lock-in clauses are connected to the transferability of shares. On one hand, the firm can benefit from the transferability of shares. The transferability of shares makes it possible to manage the share ownership structure of the company and the pool of shareholders that provide services to the firm. Moreover, the transferability of shares can reduce shareholders' perceived risk exposure and therefore even the firm's costs for funding and ancillary services. On the other, since shareholders are important agents of the firm (under the agency theory as applied in this book) and controlling shareholders are particulary important agents of both the firm and other shareholders, it is customary in corporate practice to restrict the transferability of shares. ${ }^{152}$ It would be unusual to restrict the transferability of shares as a default rule. ${ }^{153}$

In practice, both the firm and financial investors rely on controlling shareholders as agents. Both the long-term survival of the firm and the future of financial investors' investments depend on the quality of the services of the firm's controlling shareholder or shareholders. ${ }^{154}$

In venture capital practice, contract terms customarily bind the key people such as the founders to the company for a relatively long period of time. This is necessary, because the success of a start-up or growth firm depends on the personal qualities of its key people. ${ }^{155}$ It is not the business of venture capital firms to take care of the day-to-day management of portfolio companies.

Therefore, the contractual framework (including a subscription agreement, a shareholders' agreement, and other agreements) will bind key people such as

151 The Economist, Schumpeter. A new Tiger in town. How a hyperactive technology fund is changing Silicon Valley, 26 June 2021; Miles Kruppa, SoftBank's second Vision Fund speeds up pace of investment. Financial Times, 11 July 2021.

152 Mäntysaari P (2010a) section 9.5.8; Mäntysaari P (2010c) pp 169-170; Heminway JM (2017) pp $190-191$.

153 In the US, "the CROWDFUND Act” (Capital Raising Online While Deterring Fraud and Unethical Non-Disclosure Act, Title III of the JOBS Act) lays down resale restrictions. Heminway JM (2017) pp 201-202: "The restrictions on resale in the CROWDFUND Act, like other transfer restrictions, may hamper the development of a liquid trading market for the affected securities. This effect, in turn, makes it harder for investors to realize value from their investments, since they may or may not find a ready and willing buyer for their securities when they want to exit their investments. Moreover, the lack of a public market is likely to result in a marketability discount in the pricing of any investments sold."

154 Mäntysaari P (2010a) section 9.2.6 and pp 306-308.

155 See, for example, "Letter from the Founders" in Google, Inc, S-1 registration statement, 18 August 2004. 
founders to the company. The contractual framework will restrict their share transfers. They will undertake to enter into employment contracts with the company and accept non-compete obligations. Moreover, a party will not be able to assign the contractual framework in whole or in part to a third party without the prior written consent of the other parties.

The use of lock-in clauses is not limited to venture capital. In IPO practice, it is customary to bind key shareholders to the company for a certain period of time. Such terms are designed to reduce market investors' perceived risk, improve access to funding, increase the price payable for the shares, and reduce the firm's funding costs. Controlling shareholders thus matter to investors in IPO practice.

This IPO practice can be contrasted with a direct listing. In a direct listing, no new shares are issued to investors. It is not really necessary for the firm to use a lock-up period. For example, the direct listing of Spotify was a way for existing shareholders to cash out. ${ }^{156}$

SME markets "typically adopt operating practices to preserve investor interest and market integrity. These include a lock-up period for major shareholders around equity offerings (i.e. a predetermined period following an IPO where large shareholders are restricted from selling their shares), institutional arrangements for mentoring, and strict delisting rules". ${ }^{157}$ For example, the Rule Book ${ }^{158}$ of Euronext Growth Market operated by Euronext Dublin contains a Rule that lays down lock-ins for new businesses. ${ }^{159}$ These lock-ins apply for a period of one year to "Related Parties", “Applicable Employees", and "Substantial Shareholders" all defined in the Rule Book, ${ }^{160}$ but do not apply "in the event of an intervening court order, the death of a party who has been subject to this Rule or in respect of an acceptance of a take-over offer for the Issuer which is open to all Shareholders."161

Use of proceeds. In many large financial transactions, it is customary to limit the use of proceeds. For example, project finance contracts limit the use of funds

156 Spotify Technology S.A. Form F-1 Registration Statement under the Securities Act of 1933, 28 February 28; The Economist, Play list, 4 April 2018.

157 OECD (2015c) p 126.

158 Euronext Growth Markets Rule Book (Issue date: 7 June 2019. Effective Date 10 June 2019). 159 Ibid., Part II, Rule 5.2: "Where an Applicant's main activity is a business which has not been independent and earning revenue for at least two years, it must ensure that all Related Parties and Applicable Employees as at the date of Admission agree not to dispose of any interest in its Securities for one year from the Admission of its Securities ...”

160 Ibid., Part II, Rule 5.0.

161 Ibid., Part II, Rule 5.2. 
to the purposes of the project and prohibit the use of funds in other ways without the prior written consent of project finance lenders. The business plan of the project is made part of the contractual framework.

Venture capital is no exception in this respect. Venture capital contracts limit the use of funds raised from venture capital investors. For example, the company may undertake to use the raised funds pursuant to the subscription agreement in the furtherance of the company's business in accordance with the business plan.

In many large financial transactions, it is also customary to restrict distributions and asset disposals. The same applies to venture capital. It would be rather pointless to distribute venture capital investors' money as dividends to shareholders. However, the parties may agree on the rights of the holders of preference shares, and on the pari passu ranking of the dividend rights of shareholders. Moreover, the company will not grow unless it invests its money into useful assets. Asset disposals may therefore be limited and require the consent of venture capitalists when the company takes internal corporate action or complies with the contractual framework.

The contractual framework will thus set out dynamic duties to use the proceeds in particular ways. Such terms can be complemented by open standards. ${ }^{162}$ For example, the founders may undertake a duty to promote the best interests of the company and ensure that its business is conducted in accordance with good business practice and the business plan.

Exit. An exit strategy is "foremost in most venture capitalists' minds"163 and in the minds of many optimistic founders. It is customary to agree on the terms of exit in venture capital practice for this and the following reasons.

First, in digital economy, a start-up is a business venture that often is not designed to make a profit from operations. It would be difficult for a start-up to grow and gain market share from traditional profit-oriented firms without the acceptance of losses and access to equity capital to cover the losses. Operational losses are part of the founders' business model. This is summed up by Kenney and Zysman: “[R]ather than making money, the firm's sole task is to capture market share driving competitor startups and/or incumbents from the market segment by undercutting them even as the aggressor startup loses money - the capital investments subsidize the losses." 164 Founders expect to make a profit from later-stage investors or a trade sale. Kenney and Zysman summed up this as well:

162 For dynamic duties and open standards, see Mäntysaari P (2010b) pp 43, 166 -167 and 222223; Mäntysaari P (2010a) pp 110 - 111 and 175-176; Mäntysaari P (2015) p 256.

163 Berlin M (1998) p 22.

164 Kenney M, Zysman J (2019). 
"Paradoxically, a sustainable business may not be the objective and may not matter, if earlier investors, founders, and management can sell their stakes in the business at higher valuation multiples to later-stage investors or through an IPO or trade sale before the actual unit economics and profit-generating potential of a company are clarified through repeated performance."165

Second, investments made by a venture capital fund are constrained by the terms of the fund. Venture capital funds must therefore ensure rights to an exit within a certain period of time. This can increase the firm's agency costs, because there is a potential conflict between the interests of the firm and the interests of the fund. There is a similar potential conflict between the interests of the founder or entrepreneur and the interests of the fund. ${ }^{166}$

Third, exit transactions tend to require corporate action. Venture capital contracts need to lay down how parties shall vote. ${ }^{167}$

Fourth, the valuation of shares may be higher in a transaction that includes all shares in the company as the acquirer will then get better access to the company's assets. A private equity fund customarily acquires all shares in the target company as this makes it much easier to organise refinancing and distribute assets to the fund. A commercial enterprise needs all shares in the target company to fully integrate it into its existing operations.

Venture capital investors sometimes require drag-along rights that allow them to force common shareholders to vote for any transaction favoured by the VCs. A minority shareholder customarily prefers a tag-along right. A tagalong right means a right to join when the majority shareholder sells its share block. Shareholders customarily do not prefer to end up as unprotected minority shareholders after somebody has obtained control and most shares in the company. ${ }^{168}$

In traditional angel investment contracts, it is not customary to agree on the form of exit. ${ }^{169}$ This is because of angel investors' earnings logic. Angel investors make a profit if the company succeeds in raising venture capital that ultimately will lead to an exit.

165 Ibid.

166 Gilson RJ (2003) pp 1074-1075; Ibrahim DM (2008) p 1415: “As a general rule, venture capitalists require earlier exits due to the short life of venture funds and the need to make distributions to fund investors, while entrepreneurs wish to delay exit in order to extend private benefits such as a steady salary. Redemption and other specific exit rights address these potential conflicts by allocating the exit decision to venture capitalists.”

167 Broughman BJ, Fried JM (2013) p 1331.

168 Ibid., p 1331.

169 Ibrahim DM (2008) pp 1422-1423. 
In US angel investment practice, a contract term may allow the company to repurchase the stake of the angel. Such a clause is a way to get rid of bad investors. ${ }^{170}$

There are various kinds of statutory exit rights. ${ }^{171}$ To protect minority shareholders in listed companies, EU securities law provides for a statutory sell-out right. It is complemented by a statutory squeeze-out right. ${ }^{172}$ Moreover, EU securities law requires a mandatory bid in the event that a party obtains control in a listed company. ${ }^{173}$ In the US, one might ask whether Rule $10 \mathrm{~b}-5$ that targets securities fraud could be seen as a functional equivalent of the statutory sell-out right as a way to protect minority shareholders. The answer is no in the light of Santa Fe Industries. ${ }^{174}$ In this landmark decision, the Supreme Court limited the scope of Rule 10b-5 by placing principal emphasis on the words "deceptive" and "manipulative" from section 10(b) of the Securities Exchange Act of 1934. This indicates that "the Supreme Court [was] determined to relegate corporate shareholders to state remedies". ${ }^{175}$

\subsubsection{Conclusions}

We can draw several conclusions from angel funding and venture capital practices. First, start-up funding is staged. The staging of funding means that it is important to focus on transition from early-stage funding to later-stage funding. Angel investors and venture capitalists protect their rights in later funding rounds. Second, it is common practice to use multiple classes of shares. Third, start-up funding is for a certain number of years. It is common practice to bind key people and key shareholders to the project for a certain number of years. "Exits at will" would not work. ${ }^{176}$ Exit terms are an important part of the contractual framework. Fourth, the portfolio company is controlled by key shareholders or venture capital managers during the term of the investment con-

170 Wong A, Bhatia M, Freeman Z (2009) p 226: "Many entrepreneurs cite this clause as a way to rid themselves of 'bad apples' or investors whose vision does not coincide with that of the founders."

171 See Fleischer H (2018e) p 701 distinguishing between the winding-up remedy, the buyout remedy or withdrawal rights, the oppression remedy, and appraisal rights.

172 Articles 15 and 16 and recital 24 of Directive 2004/25/EC (on takeover bids).

173 Article 5 of Directive 2004/25/EC (on takeover bids).

174 Santa Fe Industries, Inc. v. Green, 430 U.S. 462 (1977).

175 Campbell RB Jr (1978) p 193.

176 For closely-held companies generally, see Fleischer H (2018e) p 704. 
tract. While angel investors do not require control, there are particular control issues in venture capital. Fund investors have no control rights in the portfolio company and very limited rights in the fund. The representatives of the venture capital management company have large control rights. They control the fund and the boards of portfolio companies. Since they act as gate-keepers to funding, they can use equity investments from the fund as leverage. There is separation of capital investment (to the fund), share ownership (in the portfolio company), and control (by fund managers).

\subsection{SME Market Design Practices}

\subsubsection{General Remarks}

From the perspective of the issuer-firm, stock exchanges provide core services and ancillary services. The core services include facilitating trading in the company's securities, providing access to market funding, and facilitating the provision of shareholders' services to the firm. For example, stock exchanges provide an exit channel for shareholders and can thus help to manage the share ownership structure of the company and the provision of shareholders' services. ${ }^{177}$ Stock exchanges provide many ancillary services connected to these core services. ${ }^{178}$

It is assumed that SME equity trading infrastructures matter: ${ }^{179}$ " [S]tock markets that provide significant economic incentives to support small companies and associated infrastructure in the aftermarket will create higher rates of capital formation that, in turn, will generate jobs, economic growth and tax receipts." 180

Where an equity trading infrastructure is instead designed for large companies, institutional investors, and for-profit intermediaries, the trading infrastructure will neither work well for SMEs nor bring them to markets: ${ }^{181}$ "Onesize-fits-all stock market structures harm SME listings, which are typically less liquid than large cap stocks and require broker-dealers to support liquidity, sales and equity research." ${ }^{182}$ There should therefore be marketplaces for SME stocks.

177 See OECD (2015c) p 129 on the usefulness of SME exchanges.

178 See ibid., p 128.

179 Market design always matters. See Ostrom E (2005); Ostrom E (2010).

180 Weild D, Kim E, Newport L (2013) p 4.

181 OECD (2015c) p 134.

182 Ibid.. See also FESE (2019) p 29. 
According to an OECD study, SME markets differ from the main stock exchanges in several ways. SME markets customarily "set looser listing and disclosure requirements", "charge lower listing and maintenance fees", and "adopt operating practices to preserve investor interest and market integrity". ${ }^{183}$

Obviously, SMEs prefer lower costs. Fees and other costs designed for large companies are discouragingly high for SMEs. According to the OECD study, SME markets customarily "charge lower listing and maintenance fees" than the main stock exchanges. ${ }^{184}$ This said, the costs for companies to list and remain listed on a platform tend to remain high. ${ }^{185}$

The question is how to reduce costs for SMEs. On one hand, SME exchanges could try to reduce costs for SMEs by lowering standards and increase their own revenue by increasing trading volumes in the short term. On the other, lower standards could reduce the quality of issuers and trading volumes in the long term. . $^{186}$

There are conflicting objectives. Generally, new business models may be necessary to reduce costs for SMEs without compromising quality, as "[p]ure forprofit models for growth platforms can have perverse incentives and cannot ensure sustained capacity to bring SMEs to the market and, equally importantly, support them in the aftermarket". ${ }^{187}$ Thinking outside the box, the new LTSE has chosen a low-cost model in which an LTSE group company earns revenue from the sale of software and services to start-ups.

It can be difficult to create a successful SME exchange balancing costs and standards. A working paper of the World Bank Group identifies approaches that "are widespread and/or could be beneficial to consider". They include the following: "(1) focus on SMEs with a sizeable growth rate, (2) have the SME exchange legally related to the main board, (3) do not reduce disclosure content to reduce costs, (4) allow private placements, (5) have well regulated advisors to vet issuers and provide comfort to investors about the quality of the issue, (6) have outreach, public awareness campaign and training for SMEs, [and] (7) consider tax incentives for investors". ${ }^{188}$ Tax incentives obviously play an im-

183 OECD (2015c) p 126. See also Table 7.4.

184 Ibid.

185 Ibid., paragraph p 128.

186 Daniel Davies, A scammer's charter for European capital markets. Financial Times, 9 November 2015: "The less rigorous the listings rules and the less onerous the reporting and prospectus criteria, the easier it is to gull investors into swapping real cash for worthless shares." 187 OECD (2015c) p 134.

188 Harwood A, Konidaris T (2015) Abstract (and p 6). See also World Federation of Exchanges (2018) p 12. 
portant role, ${ }^{189}$ but there seems to be much more to do before SME markets attract both issuers and investors and are sustainable in the long term.

Regulators should strike a balance between conflicting objectives. ${ }^{190}$ One may also ask whether listing standards should be decided on by the exchange operator or a third party. ${ }^{191}$ In the following, we will have a look at what has worked for SME exchanges in the past.

\subsubsection{Feeder Principle $\mathbf{v}$ the Nasdaq Model}

There are three models for junior stock exchanges for SMEs. The first is the sequential or feeder model under which successful feeder-listed SMEs can move on to the main market. The second is the sectorial model. Such exchanges tend to focus on tech. The third is the self-regulated exchange. The AIM is an example of such an exchange. ${ }^{192}$

Many SME exchanges have been inspired by Nasdaq. ${ }^{193}$ Operators of SME marketplaces often have chosen between the feeder principle and the so-called Nasdaq model.

When an SME marketplace operates in parallel with a main market, it can adopt a junior market strategy and act as a feeder for the main market. ${ }^{194}$ The feeder principle means that the SME marketplace is a separate board within

189 Harwood A, Konidaris T (2015) p 6; OECD (2015c) pp 131 and 134.

190 See, for example, Action Plan on Building a Capital Markets Union. Communication from the Commission, $\operatorname{COM}(2015) 468$ final, Chapter 2: "To reap the full benefits of these dedicated platforms for the CMU, the Commission will ensure through the implementation of MiFID II that the requirements applying to them strike the right balance between providing sufficient investor protection and avoiding unnecessary administrative burden."

191 See, for example, Steil B (2001) pp 343-344: "Listing is fundamentally a quality control function ... It could just as easily be performed by accounting firms or rating agencies, and done on a competitive basis.”

192 Vismara S, Paleari S, Ritter RJ (2012);

193 OECD (2015c) p 129; Posner E (2005). NASDAQ was initially an acronym for the National Association of Securities Dealers Automated Quations.

194 OECD (2015c) p 126. See, for example, NYSE Euronext, SEC Form 10-K filing for the fiscal year ended December 31, 2007, p 3, Strategy, Listings: "We intend to leverage our premier brand and position as the world's leading listings venues with the deepest global pool of liquidity to compete aggressively for new listings on a global scale. With multiple listings platforms in both the United States (the NYSE and NYSE Arca) and Europe (Euronext and NYSE Alternext), we are uniquely situated to target a highly diverse range of companies from around the world to enable the capital-raising process." 
an established exchange market. For example, Euronext Growth is based on the same pan-European trading platform as the Euronext main market.

The Nasdaq model means that the SME marketplace is developed as a separate market. AIM, KOSDAQ, and TSX Venture are examples of separate markets. ${ }^{195}$

In the late 1970s and early 1980s, new market segments were created according to the feeder principle. ${ }^{196}$ The feeder principle meant in practice looser listing and disclosure requirements. ${ }^{197}$ Exchanges that operated according to the feeder principle with lower entry requirements and lower information standards than the main market did not survive the 1987 stock market crash as "investors perceived that feeder markets quoted poorly-performing companies and preferred to wait the best ones to be promoted to the main market". ${ }^{198}$

In the 1990s, new markets chose the Nasdaq model. The Nasdaq model is characterised by relaxed listing requirements combined with high information standards. ${ }^{199}$ For example, the STAR Market operated by the Shanghai Stock Exchange (SHSE) is generally regarded as a Nasdaq-style exchange. It was "ordered into existence by Chinese President Xi Jinping” in November 2018 "as a way of bolstering mainland China's technology companies amid the US-China trade war" and started its operations in July 2019. ${ }^{200}$ The STAR Market is controlled by the state. ${ }^{201}$

This said, the STAR Market is even an example of the feeder model, the junior exchange model, and the multi-tiered capital market of China with secondtier segments in the two senior stock exchanges SHSE and Shenzen Stock Exchange (SZSE). The National Equities Exchange and Quotations (NEEQ) was designed to serve the financial needs of SMEs. The NEEQ market was made accessible to SMEs by replacing the traditional merit regulation with a registration regime and removing most entry barriers. The NEEQ market is highly illiquid but offers more opportunities to raise finance. ${ }^{202}$

195 OECD (2015c) p 126.

196 Ibid., p 132.

197 Ibid., p 126. See also Table 7.4.

198 Ibid., p 132.

199 Ibid.

200 Daniel Ren, Shanghai Stock Exchange to debut Nasdaq-style market for tech stocks on July 22, three weeks ahead of schedule, South China Morning Post, 5 July 2019.

201 Hudson Lockett, 'China's Nasdaq': Shanghai's new tech trading venue explained. Financial Times, 19 July 2019. See also Rules Governing the Review of Offering and Listing of Stocks on the Science and Technology Innovation Board of Shanghai Stock Exchange (1 March 2019).

202 Xu W, Zhu S, Wu Z (2020). 


\subsubsection{Relaxed v Strict Listing Requirements and Disclosure Requirements}

To reduce costs for SMEs, requirements should be relaxed. The choice is between strict or relaxed listing requirements and between strict or relaxed ongoing disclosure requirements. The adoption of relaxed requirements can be complemented by mentoring and pre-IPO incubators.

Strict $v$ relaxed listing requirements. It is customary for SME exchanges to adopt relaxed listing requirements. Generally, such listing requirements include "more relaxed criteria on operating history, minimum number of shareholders, past financial performance and number of free-float shares". ${ }^{203}$

The choice of relaxed listing requirements can be illustrated with the London Stock Exchange's AIM Rules. They seem to have worked very well. ${ }^{204}$ The entry criteria for AIM "do not include requirements for trading record, minimum size, prescribed levels of shares held by the public, nor they demand pre-vetting of admission documents by the Exchange or by the United Kingdom Listing Authority (UKLA)" ${ }^{205}$ Neither do the AIM Rules require compliance with a corporate governance code: "The AIM Rules do not mandate any corporate governance code or disclosures. However, companies need to provide details on their website as to whether or not they have followed a governance code and, if they have not, narrative details of their practices." ${ }^{206}$ AIM has relatively simple listing requirements, because it was originally designed as a secondary market only. The primary market operates as private placements. Since there are no US-style resale restrictions after private placements, the secondary market can work for both retail and professional investors. AIM originally benefited from the lighter regulation of MTFs. The trend of ensuring a level playing field in EU securities law increased the cost of AIM access and contributed to a decline in AIM listings. ${ }^{207}$

Sometimes market integrity can be fostered by standards that are higher than in the main market. This can be the case when the benchmark is Nasdaq but the main market has lower standards. This was the case with Brazil's Novo Mercado and Deutsche Börse's Neuer Markt.

203 OECD (2015c) p 126.

204 Armour J, Bengtzen M, Enriques L (2018) p 439: "Empirical studies suggest that firms that list on AIM are typically smaller and younger than those listing on the Main Market, and that they join AIM to take advantage of its lower costs. AIM-listing firms are not, however distinguishable from Main Market firms in terms of market valuation or risk of failure.”

205 OECD (2015c) p 126.

206 Ibid.

207 Armour J, Bengtzen M, Enriques L (2018) pp 439 - 440. 
Novo Mercado's approach can be illustrated by comparing the standards for corporate governance and shareholders' rights in the Novo Mercardo market and in the Level 2 segment of the BOVESPA market of the São Paulo Stock Exchange. They were compared in an OECD study: ${ }^{208}$

- Novo Mercado, corporate governance and shareholders' rights: "Issue only voting shares. Give tag-along rights to all shareholders at the full price of the deal. Make a public tender offer at least at the economic value in case of delisting or cancellation of the Novo Mercado's contract with BOVESPA. The board of directors must have a minimum of five members, all with unified mandates of up to two years, and a minimum of 20 percent of independent board members. Discuss through arbitration any shareholder-company dispute that arises related to the listing rules, the company bylaws, Corporate Law provisions, and other norms of the Brazilian capital market. The company also commits to maintain at least a 25-percent free float."209

- BOVESTA, Level 2: "Requires companies to abide by all of the obligations set forth in the Novo Mercado regulations, with a few key exceptions. First, Level 2 companies retain the right to maintain existing preferred shares and issue new ones up to the level permitted by the law. These preferred shares enjoy tag-along rights at the minimum of 80 percent of the price received by the selling controlling shareholder and are also entitled to voting rights in some key situations (such as company mergers and incorporations and contracts between the controlling shareholder and the company), provided they are voted in a general shareholders' meeting." 210

Strict $v$ relaxed ongoing disclosure requirements. The Nasdaq model is characterised by low listing requirements combined with high information standards. ${ }^{211}$ In the 1990s, the Nasdaq model prevailed. It is now understood that costs should not be reduced by reducing disclosure content. It is regarded as better to reduce "other requirements, such as the frequency of submitting disclosure documents and allowing online dissemination rather than requiring printed materials". ${ }^{212}$

Mentoring. One may ask what will happen if listing requirements are relaxed. Will the quality of listed companies become worse? Will issuers understand the

208 OECD (2015c) pp 127-128.

209 Ibid., Box 7.4.

210 Ibid.

211 Ibid., p 132.

212 Harwood A, Konidaris T (2015) p 6. See also Daniel Davies, A scammer's charter for European capital markets. Financial Times, 9 November 2015. Davies mentions the cases of Gowex and Globo as bad examples. 
culture of the market? Will the integrity of markets suffer? One of the practices to preserve market integrity is mentoring. ${ }^{213}$

The use of an educator-monitor can improve the quality of issuers and increase the level of integrity, transparency, corporate governance, and investor protection in general. ${ }^{214}$ Mentoring is in other words intended as a functional equivalent to traditional compliance obligations. ${ }^{215}$

For example, mentoring is used by AIM and Euronext Growth. The AIM Rules require the company to work closely with a Nominated Adviser ("Nomad") 216 during the admission process and its time as a public company: "A Nomad undertakes extensive due diligence to ensure that a company is suitable for AIM, provides guidance throughout the flotation process, prepares the company for being on a public market, helps prepare the AIM admission document, confirms appropriateness of the company to the Exchange, and acts as the primary regulator throughout a company's time on AIM". ${ }^{217}$

Euronext Growth uses listing sponsors. ${ }^{218}$ The listing sponsor "is usually an investment bank, but can also be an advisory firm, such as an accountant or corporate finance boutique, which will work alongside an investment bank". ${ }^{219}$ The listing sponsor will cooperate with the company and its legal advisers and auditors.

The company must have a listing sponsor before it applies for a listing on Euronext Growth. The listing sponsor considers whether the company meets all applicable criteria for listing. Moreover, an issuer must have a listing sponsor on a permanent basis after admission.

Before Alternext became Euronext Growth, ${ }^{220}$ the Alternext model of using listing sponsors was described in an OECD report as follows: "Companies that seek to be listed on Alternext have to choose a listing sponsor to assist them during the admissions procedure and guide them throughout their time of listing on Alternext. The listing sponsor is a company acting as an investment-services pro-

213 OECD (2015c) pp 126 and 134-135.

214 Ibid., pp 130.

215 For nudging, see Thaler RH, Sunstein CR (2008).

216 London Stock Exchange, AIM Rules for Nominated Advisers (July 2018).

217 OECD (2015c) pp 126.

218 See Euronext Growth Markets Rule Book (Issue date: 7 June 2019. Effective Date 10 June 2019), Part I, Rule 4.7 and Appendix IV.

219 Euronext website.

220 Euronext Growth Markets Rule Book (Issue date: 7 June 2019. Effective Date 10 June 2019), Part I, Rule 1.1: “... Alternext Market: An multilateral trading facility within the scope of Article 4(1)(22) of MIFID operated by the respective Euronext Market Undertakings under the commercial name 'Euronext Growth' ...” 
vider, audit firm, legal counsel or corporate finance specialist. It assesses a company's suitability for listing, participates in drafting the prospectus or offering circular, it coordinates the due diligence process and liaises with the regulator and/or the market operator of Alternext."221

Pre-IPO incubators. SME exchanges can invest more in pre-IPO services such as pre-IPO incubators. Trends in the development of the pre-IPO services of SME exchanges can be illustrated with the cases of the Long-Term Stock Exchange (LTSE) in the US and Deutsche Börse Venture Network in Germany.

Deutsche Börse Venture Network is Deutsche Börse's customised pre-IPO service offering for young companies. It was launched in 2015. For firms, Deutsche Börse Venture Network means support in the raising of angel and venture capital funding and a range of specially developed services. For venture capital investors, Deutsche Börse Venture Network gives access to a network of aspiring enterprises and investment opportunities. For Deutsche Börse, the service offering is a way to increase IPOs in the future.

The Long-Term Stock Exchange (LTSE) is marketed as "the only U.S. stock exchange with a mission to help companies create lasting businesses and empower long term-focused investors". In the marketing of the exchange, the stated intention of LTSE is to "enable companies to prioritize the long term". This will be achieved by listing rules: "[W]hen companies list with the exchange to sell shares to the public, they will adopt a set of governing practices that mirror their long-term horizon."222

There is relatively little room for innovation because of the mandatory legal framework for national securities exchanges. ${ }^{223}$ In any case, LTSE is designed to combine the characterististics of a start-up incubator and a traditional exchange. ${ }^{224}$ LTSE is backed by the Long-Term Investor Coalition (LTIC), "a network of institutional investors that share LTSE's mission of empowering long term-focused companies and commitment to creating value over time". ${ }^{225}$ The listing standards of LTSE are intended to foster long-term value creation. ${ }^{226}$ LTSE will also reduce fees for issuers as LTSE sells software tools to company builders.

221 OECD (2015c) Box 7.5, NYSE Alternext trading model.

222 The website of LTSE, Frequently asked questions. See also Cydney Posner, Will the LongTerm Stock Exchange Make a Difference? Harvard Law School Forum on Corporate Governance, Saturday, June 8, 2019.

223 See SEC Release No. 34-85828 (May 10, 2019).

224 The Economist, NOIPO? 16 May 2019.

225 The website of LTSE, Frequently asked questions.

226 LTSE, The Long-Term Stock Exchange proposes enhanced listing standards for a new generation of public companies. New York, 26 June 2019. 
The website of LTSE sums up this approach as follows: "We are building software tools and a coalition of investors for 21st-century companies."

\subsubsection{Dealing with Illiquidity}

SME exchanges can deal with the inherent illiquidity of SME shares in various ways in their trading rules.

First, they can foster long-termism in share ownership and limit day-to-day trading by favouring buy-and-hold strategies. This is because firms have longterm interests and long-termism is necessary to ensure market integrity in an environment with low trading volumes. ${ }^{227}$ However, institutional investors dislike buy-and-hold strategies that limit day-to-day trading. ${ }^{228}$

Second, SME exchanges can use market makers or other liquidity providers. It is customary to use market makers to provide sufficient liquidity in SME markets. In Regulation NMS, ${ }^{229}$ the SEC defines a "market maker" as a firm that stands ready to buy and sell stock on a regular and continuous basis at a publicly quoted price. ${ }^{230}$ MiFID II contains a similar definition. ${ }^{231}$ According to an OECD report, "the existence of well-functioning market-making systems is instrumental to the fostering of SME markets, where information asymmetries lead to potentially high monitoring costs relative to the level of investment and low levels of liquidity act as an important deterrent to public investment in SME equities”.232 For example, Euronext Growth uses Liquidity Providers. ${ }^{233}$

227 OECD (2015c) p 130.

228 OECD (2015c) Box 7.5 and p 130.

229 SEC Release No. 34-51808 (June 9, 2005) (Regulation NMS).

230 Rule 600(b)(24) of Regulation NMS: "Exchange market maker means any member of a national securities exchange that is registered as a specialist or market maker pursuant to the rules of such exchange." Rule 600(b)(52) of Regulation NMS: “OTC market maker means any dealer that holds itself out as being willing to buy from and sell to its customers, or others, in the United States, an NMS stock for its own account on a regular or continuous basis otherwise than on a national securities exchange in amounts of less than block size."

231 Article 4(1) of Directive 2014/65/EU (MiFID II): "For the purposes of this Directive, the following definitions apply: ... (7) 'market maker' means a person who holds himself out on the financial markets on a continuous basis as being willing to deal on own account by buying and selling financial instruments against that person's proprietary capital at prices defined by that person; ..."

232 OECD (2015c) p 130.

233 Euronext Growth Markets Rule Book (Issue date: 7 June 2019. Effective Date 10 June 2019), Part I, Rule 1.1: “... Liquidity Provider: any Member that has been appointed by the Relevant Eu- 
Third, if market makers are employed to increase liquidity, they should be given adequate economic incentives. Profitable market-making creates an incentive to generate trading volume. Therefore, "[t]he ability of market makers to earn a profit on capital deployed is necessary to support smaller company stocks that trade episodically, rather than continuously, and require constant support through marketing and capital commitment”. ${ }^{234}$

Markets with higher tick sizes for SME equity trading tend to have higher levels of IPO activity. ${ }^{235}$ The declining trend in trading spreads and tick sizes "may have reduced transaction costs for investors", but it also "has generated disincentives for intermediaries of small caps, undermining the infrastructure and services required to support their development". ${ }^{236}$

Fourth, one can provide alternative trading methods depending on the level of liquidity. For example, the Euronext Growth model (formerly known as the NYSE Alternext model) ${ }^{237}$ combines different trading methods: 238 "Depending on the liquidity of the relevant Security, trades are executed through auction or continuously, according to the allocation principles specified in the Euronext Cash Market Trading Manual." ${ }^{239}$ Investors can thus execute trades either in the Central Order Book ${ }^{240}$ or outside the Central Order Book depending on liquidity. ${ }^{241}$

Fifth, one can use lock-ins to deal with the potential problems of illiquidity. According to an OECD study, SME markets "typically adopt operating practices to preserve investor interest and market integrity. These include a lock-up period for major shareholders around equity offerings (i.e. a predetermined period following an IPO where large shareholders are restricted from selling their shares),

ronext Market Undertaking, to enhance the market liquidity of a particular Admitted Financial Instrument ...”

234 OECD (2015c) p 132. Citing Weild D, Kim E, Newport L (2013) p 17.

235 Weild D, Kim E, Newport L (2013) p 3.

236 OECD (2015c) p 134.

237 Euronext Growth Markets Rule Book (Issue date: 7 June 2019. Effective Date 10 June 2019), Part I, Rule 1.1: “... Alternext Market: An multilateral trading facility within the scope of Article 4(1)(22) of MIFID operated by the respective Euronext Market Undertakings under the commercial name 'Euronext Growth' ...”

238 See also OECD (2015c) Box 7.5.

239 Euronext Growth Markets Rule Book (Issue date: 7 June 2019. Effective Date 10 June 2019), Part I, Rule 6.3.3.

240 Ibid., Part I, Rules 6.3.1 and 1.1: “... Central Order Book: that part of the trading platform of the Euronext Growth Markets in which all submitted orders and any modifications thereto are held until matched, expired or withdrawn ...”

241 Ibid., Part I, Rule 6.4. 
institutional arrangements for mentoring, and strict delisting rules". ${ }^{242}$ For example, the Euronext Growth Market operated by Euronext Dublin applies lock-ins for new businesses. ${ }^{243}$ These lock-ins apply for a period of one year to "Related Parties", "Applicable Employees", and "Substantial Shareholders". ${ }^{244}$ AIM applies lock-ins for new businesses. ${ }^{245}$

Sixth, one can facilitate analyst coverage. Analyst coverage generates trading volume, increases demand, and increases the share price. ${ }^{246}$

In the light of such market practices, there is a lot market regulation can do.

First, governments can ensure that there is a better market infrastructure for trading in inherently illiquid SME stocks. One-size-fits-all stock market structures harm SME listings. ${ }^{247}$

Second, governments can ensure that there are proper economic incentives for broker-dealers and providers of investment research in the secondary market. The market is not sustainable without such incentives. ${ }^{248}$

Third, government policies can address the lack of liquidity in SME equity markets through measures that foster retail investment. For example, the JOBS Act of 2012 created more room for retail investors by raising the threshold at which public disclosure and related requirements kick in under Section 12(g) of the Exchange Act. ${ }^{249}$ The JOBS and Investor Confidence Act of 2018 (also known as JOBS Act 3.0) would have created more room for emerging growth companies and retail investors but was not passed by the Senate.

Fourth, governments can reduce liquidity by charging taxes on SME securities transactions and increase liquidity by abolishing such taxes. For example, UK stamp duties are from April 2014 no longer chargeable on transactions in el-

242 OECD (2015c) p 126.

243 Euronext Growth Markets Rule Book (Issue date: 7 June 2019. Effective Date 10 June 2019), Part II, Rule 5.2.

244 Ibid., Part II, Rule 5.0.

245 London Stock Exchange, AIM Rules for Companies (effective 3 January 2018), Part One AIM Rules, rule 7: “Where an applicant's main activity is a business which has not been independent and earning revenue for at least two years, it must ensure that all related parties and applicable employees as at the date of admission agree not to dispose of any interest in its securities for one year from the admission of its securities."

246 Demiroglu C, Ryngaert M (2010).

247 OECD (2015c) p 134.

248 Ibid., p 132; Weild D, Kim E, Newport L (2013) p 3: "Broker-dealers, who are the facilitators of capital formation, must have adequate incentives in order to support small company IPO activity."

249 OECD (2015c) p 134. 
igible securities on the London Stock Exchange's AIM and High Growth Segment. 250

Fifth, there should be a corporate governance model that makes it easier for firms and investors to replace short-term exits with long-term voice and loyalty (section 5.4.5)..$^{251}$

\subsubsection{Corporate Governance Model}

Small firms and large firms need different corporate governance models. The existence of many layers of hierarchy and the separation of work in large firms may hamper information flows and make it more difficult for large firms to adapt to changes in the marketplace. ${ }^{252}$ A small firm tends to have fewer layers of hierarchy and less separation of work. Moreover, there is less separation of share ownership and management in a small firm.

The different needs of small and large firms were recognised in continental European company law in the nineteenth century (section 2.4.9). The needs of different kinds of firms help to explain why continental European company laws distinguished between partnerships, limited partnerships, and limited-liability companies (sociétés en nom collectif, sociétés en commandite, sociétés anonyme; offene Handelsgesellschaften, Kommanditgesellschaften, Aktiengesellschaften). Moreover, the German $\mathrm{GmbH}$ Act of 1892 was adopted after the limited-liability company form had been adapted to the needs of larger firms in the company law reform of 1884 and become too heavy for small firms.

The governance model that parties tend to choose in venture capital transactions is designed for relatively small firms. In venture-capital-funded firms, founders and entrepreneurs are the key people, the number of employees is small, managers and employees can be shareholders, and venture capitalists provide important ancillary services in addition to funding.

SME exchanges should, therefore, take the particular characteristics of SME firms into account in the context of corporate governance. To some extent this seems to be the case as can be illustrated with the different practices of Euronext Growth and AIM.

250 Ibid.

251 See Hirschman AO (1970) on the notions of exit, voice, and loyalty.

252 Williamson OE (1984). 
Euronext Growth was preceded by Alternext. Companies that sought to be listed on Alternext were required to choose a listing sponsor. ${ }^{253}$ Like its predecessor, Euronext Growth requires the use of a Listing Sponsor as a monitoring, mentoring, and nudging mechanism. ${ }^{254}$ However, the rules of Euronext Growth do not require the use of any particular board structure or composition. This is understandable in the light of the fact Euronext Growth Market rules are embedded in a wider legal framework and designed to be used in all European jurisdictions in which Euronext operates a Growth Market.

The Euronext Growth Market Operated by Euronext Dublin is an exception. The particular rules for the Euronext Growth Market Operated by Euronext Dublin require disclosure on a website of "details of the corporate governance code that the Issuer has decided to apply, how the Issuer complies with that code, or if no code has been adopted this should be stated together with its current corporate governance arrangements". ${ }^{255}$ In the Dublin market, an issuer must also ensure that its board members are responsible for compliance with the Euronext Growth Markets Rule Book. ${ }^{256}$

Like Euronext Growth, the London Stock Exchange's AIM is embedded in a wider legal framework. ${ }^{257}$ Unlike Euronext Growth, however, the framework is that of one country only with the regulation of the London Stock Exchange's

253 OECD (2015c) p 131, Box 7.5: "Companies that seek to be listed on Alternext have to choose a listing sponsor to assist them during the admissions procedure and guide them throughout their time of listing on Alternext. The listing sponsor is a company acting as an investment-services provider, audit firm, legal counsel or corporate finance specialist. It assesses a company's suitability for listing, participates in drafting the prospectus or offering circular, it coordinates the due diligence process and liaises with the regulator and/or the market operator of Alternext." 254 Euronext Growth Markets Rule Book (Issue date: 7 June 2019. Effective Date 10 June 2019), Part I, Rule 4.7.1. Instead of a Listing Sponsor, a Growth Advisor is used in the Dublin market. Ibid., Part II, Rule 5.27.

255 Ibid., Part II, Rule 5.26.

256 Ibid., Part II, Rule 5.24: “An Issuer must: (a) have in place sufficient procedures, resources and controls to enable it to comply with these Rules; ... (d) ensure that each of its Directors accepts full responsibility, collectively and individually, for its compliance with these Rules ..." 257 London Stock Exchange, AIM Rules for Companies (effective 3 January 2018), Introduction: "AIM is a market for smaller and growing companies and is a multilateral trading facility within the meaning set out in the Handbook of the FCA and is a SME growth market. AIM is operated and regulated by the Exchange in its capacity as a Recognised Investment Exchange under Part XVIII of FSMA 2000, as such AIM is a prescribed market under FSMA 2000 ... AIM companies also need to comply with any relevant national law and regulation as well as certain European Commission Directive standards and regulations where applicable, such as MAR, the DTR and the Prospectus Rules.” 
main market as a benchmark. All "member firms" must comply with the Rule Book of the London Stock Exchange. ${ }^{258}$

The AIM corporate governance rules are mainly designed for the English plc. ${ }^{259}$ The particular characteristic in the regulation of corporate governance in AIM relates to the use of "nominated advisers" as monitors and mentors. ${ }^{260}$ Moreover, AIM requires half-yearly reports rather than quarterly reports. ${ }^{261}$ There are even other differences between AIM and the main market. ${ }^{262}$

The AIM Rules require no prior shareholder approval for most transactions unless the transaction is a reverse takeover or disposal resulting in a fundamental change of business. However, a statutory legal capital regime has allocated power to shareholders in many company law transactions relating to shares or equity capital in the EU. ${ }^{263}$ The EU legal capital regime still applies to the extent that the law that governs company law matters is the law of a Member State of the EU.

English company law statutes traditionally have been light on corporate governance rules with the most important rules based on the company's articles of association (section 2.4.10). Company law statutes traditionally have played a greater role in continental Europe.

258 London Stock Exchange, Rules of the London Stock Exchange. Rule Book (effective date 1 July 2019).

259 London Stock Exchange, AIM Rules for Companies (effective 3 January 2018), Part Two Guidance Notes: "Eligibility for AIM. An AIM company or applicant must be appropriate for AIM's regulatory framework. An AIM company or applicant should usually be a similar structure to a UK plc ... It should not be complex in terms of its structure and securities and should issue primarily ordinary shares (or equivalent)."

260 London Stock Exchange website, AIM Regulatory Landscape - Who’s Who: “... A key feature of AIM is the nominated adviser role. Nominated advisers are firms that provide corporate finance advice with particular expertise on AIM and are approved by the Exchange to act for companies that have, or wish to have, their securities admitted to trading on AIM. They will advise and guide the company on its ongoing obligations under the Exchange's AIM rule books. A company admitted to AIM is required to have a nominated adviser at all times whilst it has securities admitted to trading."

261 London Stock Exchange, AIM Rules for Companies (effective 3 January 2018), Part One AIM Rules, rule 18.

262 See OECD (2015c) p 127, Table 7.4 on differences between admission criteria and continuing obligations for London Stock Exchange's AIM and Main Market.

263 See Directive (EU) 2017/1132 of the European Parliament and of the Council of 14 June 2017 relating to certain aspects of company law; Mäntysaari P (2010c) sections 5.3-5.4. 


\subsubsection{Investment Research}

IPOs and secondary trading are more likely to succeed when they are supported by investment research. In the absence of easily available investment research for SME offerings, it would be more difficult for retail investors to participate.

The availability of investment research seems to be unsatisfactory and a problem: "the recent decline in equity research and inactive secondary markets for small cap offerings imply that only those institutional investors that command a special expertise in the relevant industry sector are likely to participate". ${ }^{264}$

In the US, SME equity research was hampered by the SEC's Regulation Fair Disclosure (Regulation FD) of 2000. When an issuer discloses material nonpublic information to certain individuals or entities, the issuer must make public disclosure of that information under Regulation FD. An unintended consequence of this was that "institutions stopped paying a premium" for investment research, which reduced the coverage of many companies. ${ }^{265}$

The availability of SME equity investment research has been reduced in the EU as well. Investment research is regarded as an "ancillary service" under MiFID II. ${ }^{266}$ MiFID II requires the separation of all costs and associated charges relating to both investment and ancillary services, including the cost of advice. ${ }^{267}$ MiFID II and the Commission's Delegated Regulation ${ }^{268}$ require sell side firms to disclose the associated costs and charges to the buy side. ${ }^{269}$ Previously, brokers would often bundle research with the fee they charged for executing trades. Designed to reduce spreads in already liquid securities, ${ }^{270}$ increase trading volumes in the main markets, and foster the business of large and specialised research firms, this part of the MiFID II regime is widely believed to have

264 OECD (2015c) p 132.

265 Weild D, Kim E, Newport L (2013) p 19.

266 Section B of Annex I to Directive 2014/65/EU (MiFID II).

267 Article 24 of Directive 2014/65/EU (MiFID II). See also recital 72 of Directive 2014/65/EU (MiFID II).

268 Commission Delegated Regulation (EU) 2017/575 of 8 June 2016 supplementing Directive 2014/65/EU of the European Parliament and of the Council on markets in financial instruments with regard to regulatory technical standards concerning the data to be published by execution venues on the quality of execution of transactions.

269 Ibid., recital 11 and Article 5. See also ESMA (2019) Chapter 7 on the interpretation of rules on inducements (research).

270 See recital 62 of Directive 2014/65/EU (MiFID II). 
reduced good quality research for the smaller and mid-tier stocks. This in turn may reduce the liquidity of SME markets. ${ }^{271}$

A 2015 OECD study recommended the creation of "a conducive environment for small cap and SME equity research, brokers, sales, ratings and specialised SME banks". ${ }^{272}$

In July 2018, SME equity research was mentioned in the bipartisan JOBS and Investor Confidence Act of 2018 (JOBS Act 3.0). One of the 32 individual bills in JOBS 3.0 was the Improving Investment Research for Small and Emerging Issuers Act. This bill would have required the SEC to carry out a study to evaluate the issues affecting the provision of research coverage for small issuers and preIPO companies, including emerging growth companies and other small issuers.

\subsubsection{Excursion: Neuer Markt and Scale}

What works and what does not work for SME exchanges can be illustrated with earlier experiences from Neuer Markt and the more recent experiences from Scale.

Neuer Markt. Neuer Markt was Deutsche Börse's attempt to create a technology-focused junior market for growth companies without changing the regulation of the established market. Neuer Markt was thus an example of regulatory dualism. ${ }^{273}$ The listing requirements were partly designed for small and young high-growth companies, ${ }^{274}$ partly stricter than those applicable in the main mar-

271 PwC (2016) p 6: "A potential unintended side effect on the industry could be the reduction of good quality research for the smaller and mid tier stocks. This could be both because mid tier firms stop producing research, but also because the buy side, who now need to demonstrate value for research being paid for, are less prepared to explicitly make payments for the analysis. This in turn may reduce the liquidity of these markets and lead to a widening of spreads for certain products. This is contrary to the intention of the regulators, who were seeking to tighten spreads with MiFID II to provide better value to end investors.” Hannah Murphy, Mifid II impact on small and mid-cap brokers fuels consolidation talk. New European investment research rules trigger sharp drop in commissions. Financial Times, 18 August 2018.

272 OECD (2015c) p 134.

273 For the founding of Neuer Markt, see Plückelmann K (2000). For regulatory dualism see LaPorta R, Lopez-de-Silanes F, Shleifer A, Vishny R (2000) p 22; Gilson RJ, Hansmann H, Pargendler M (2011) p 504.

274 Vitols S, Engelhardt L (2005) pp 5-6; Vitols S (2001) p 556: “One important aspect of the Neuer Markt is the waiver of minimum requirements regarding profitability and age of IPO candidates. A second aspect is the requirement that all listed companies have at least one designated sponsor, i.e. a bank or brokerage house obligated to 'make markets' for their shares.” 
ket (amtlicher Handel, the Official Market) $)^{275}$ and intended to be comparable to Nasdaq's requirements.

Neuer Markt grew fast after its opening in 1997 and became Europe's premier segment for high-growth companies. ${ }^{276}$ About one-sixth of them were foreign companies. ${ }^{277}$

Neuer Markt did not create the equivalents of Silicon Valley and Nasdaq ecosystems in Germany. Venture capital of the private kind played a much smaller role in Germany. ${ }^{278}$ Venture capitalists rarely participated in the governance of Neuer-Markt-listed companies whose governance model tended to be that of a traditional Mittelstand firm. ${ }^{279}$ Most German companies listed on Neuer Markt were neither start-ups nor loss-making. ${ }^{280}$ Most Neuer-Markt-listed software companies preferred incremental innovation rather than blockbuster products. ${ }^{281}$

Neuer Markt peaked in 2000 and went into a downward spiral. On the surface, the spiral was caused by the bursting of the dotcom bubble ${ }^{282}$ and the loss of investors' trust in the market itself following a string of profit warnings, insider dealing investigations, and insolvencies. ${ }^{283}$ At a deeper level, it was also caused by Neuer Markt's narrow industry focus on high-tech companies, and bad luck in timing. ${ }^{284}$ Moreover, Neuer Markt's standards played a role. Its listing requirements were supposed to be strict, but their enforcement did not convince

275 Gilson RJ, Hansmann H, Pargendler M (2011) p 503; Burghof HP, Hunger A (2003); Vitols S, Engelhardt L (2005) pp 5-6: "Specific features of the Neuer Markt included: • Greater transparency for investors, particularly for smaller 'outsider' investors who did not have intimate access to company management. Companies listing on the Neuer Markt were required to report on a quarterly basis (i.e. more frequently than companies on the main market). Furthermore, international accounting standards (US-GAAP or IAS), which were considered more reliable than the German HGB standards, were to be used; • Liberal listing requirements, which allowed relatively new companies as well as loss-making companies to get a listing; • Increased protection for small shareholders, for example in defining a minimum period of time after the IPO during which inside investors could not sell their shares ('lock-up period'). • Greater liquidity, that is, the ability to buy or sell shares near the current market price, provided though a system of designated sponsors obligated to provide bid-ask market quotes (prices at which the designated sponsor would buy or sell shares).”

276 Vitols S (2001) p 556; Vitols S, Engelhardt L (2005) p 7.

277 Vitols S (2001) p 557.

278 Ibid., p 559.

279 Ibid., p 559.

280 Ibid., p 560.

281 Ibid., p 561.

282 Baums T, Hutter S (2003) p 789.

283 Steil B (2001) pp 343-344; Gilson RJ, Hansmann H, Pargendler M (2011) p 505.

284 Gilson RJ, Hansmann H, Pargendler M (2011) p 507; Vitols S (2001) p 556. 
investors. ${ }^{285}$ Deutsche Börse decided to improve the standards, ${ }^{286}$ but investors' trust could not be restored. Changes in legislation gave Deutsche Börse an incentive to close Neuer Markt. ${ }^{287}$ The segment was closed in 2002 with a bad reputation. ${ }^{288}$

Scale. In 2014, MiFID II introduced SME growth markets as a stepping-stone for listings on normal exchanges. ${ }^{289}$ According to MiFID II, the SME growth market is a new sub-category within the category MTF. ${ }^{290}$ SME growth markets are subject to lighter regulatory requirements. ${ }^{291}$ This influenced Deutsche Börse as well.

In 2015, the German government asked Deutsche Börse to create a new exchange segment for start-ups. ${ }^{292}$ Deutsche Börse first launched Deutsche Börse Venture Network as a pre-IPO platform for start-ups. In a stakeholder survey, though, it turned out that what was needed was not a segment exclusively for start-ups, but rather a segment for SMEs. ${ }^{293}$ What followed was the introduction

285 Deutsche Börse AG (ed) (2001); Shearman \& Sterling (2001); Gilson RJ, Hansmann H, Pargendler M (2011) p 506.

286 See Steil B (2001) pp 343-344.

287 Baums T, Hutter S (2003) pp 779-780; Damrau J (2003) p 342: “Obwohl der Neue Markt das mit Abstand größte an den deutschen Börsen bestehende qualifizierte Handelssegment im Freiverkehr darstellt, sind seine Tage in der jetzigen Form gezählt ... Es ist ... zu erwarten, dass die Frankfurter Wertpapierbörse das Angebot des Gesetzgebers im Vierten Finanzmarktförderungsgesetz annimmt und den Neuen Markt auf eine gänzlich öffentlich-rechtliche Basis stellt.”

288 See, for example, Burghof HP, Hunger A (2003); Vitols S, Engelhardt L (2005) p 8; Gilson RJ, Hansmann H, Pargendler M (2011) pp 505 and 507; Daniel Davies, A scammer's charter for European capital markets. Financial Times, 9 November 2015: "Few things did more long-term damage to the development of an equity investment culture in Europe than the rise and fall of the Neuer Markt."

289 See Action Plan on Building a Capital Markets Union. Communication from the Commission, $\operatorname{COM}(2015) 468$ final, Chapter 2.

290 Point 12 of Article 4(1) of Directive 2014/65/EU (MiFID II).

291 Article 33(3) of Directive 2014/65/EU (MiFID II).

292 Deutsche Börse AG (2017); Kröner A, Jones K (2016): "Weil sich viele kleine Firmen in Deutschland bei der Suche nach Kapital aber sehr schwer tun, forderte der damalige Wirtschaftsminister Philipp Rösler (FDP) bereits 2013 eine Wiederbelebung des Neuen Marktes. Sein Nachfolger Gabriel (SPD) machte sich dann für einen Markt 2.0 stark. Ein eigenes Segment für Internet- und Tech-Firmen lehnte die Deutsche Börse jedoch ab, weil es dafür aus ihrer Sicht in Deutschland nicht genügend geeignete Kandidaten gibt.”

293 Deutsche Börse AG (2017), interview with Renata Bandov: "In 2015, the German government asked us to create a new exchange segment for start-ups. This prompted us to launch Deutsche Börse Venture Network, a pre-IPO platform on which we successfully connect start-ups with investors from around the world. Late-stage companies within Venture Network were increasingly focusing on finding the right segment for their IPO. However, the Entry Standard, our former 
of Scale as a segment on FWB® the Frankfurt Stock Exchange. Scale started on 1 March 2017.

What is Scale? FWB® the Frankfurt Stock Exchange distinguishes between the Regulated Market (under public law) and the Open Market (under private law). The Regulated Market is an organised market for regulatory purposes. ${ }^{294}$ In the Regulated Market, an IPO leads to a listing in the General Standard or the Prime Standard. The Prime Standard is a segment subject to additional follow-up duties and thus higher transparency requirements. The blue chip index DAX is limited to the Prime Standard segment. The Open Market (Freiverkehr) is an MTF. Since it is a private-law market for regulatory purposes, it is regarded as an unofficial market regulated by the exchange itself. In the Open Market, a company's securities can be listed on the Quotation Board, the Basic Board, or Scale.

Scale was designed not to repeat the mistakes of Neuer Markt. ${ }^{295}$ Scale replaced the Open Market's Entry Standard. "In contrast to the Entry Standard, Scale has higher standards regarding both inclusion and follow-up requirements, and it provides additional new services for issuers". ${ }^{296}$ Since 16 December 2019, the Scale segment for SMEs has been registered as an SME Growth Market.

Companies admitted to Scale must have a market capitalisation of at least of $€ 30$ million and fulfil requirements relating to turnover, equity capital, annual

segment in the regulated unofficial market, was no longer attractive, neither to companies nor to investors. We extensively talked to market participants - resulting in more than 200 interviews with companies, investors and banks, as well as with law firms and agencies. The results were unanimous: what we needed was not a segment exclusively for start-ups, but rather a segment for SMEs. In this context, it is crucial to have listing prerequisites which fit the individual target groups. Factors such as visibility, transparency, comparability, liquidity, and investor diversification play an important role. Scale reflects that."

294 Section 2(5) of the WpHG (the German Securities Trading Act).

295 Kröner A, Jones K (2016): “Um eine Skandalserie wie am Neuen Markt zu verhindern, baut die Deutsche Börse dieses Mal eine Reihe von Schutzmechanismen ein: Firmen müssen bestimmte Mindestanforderungen erfüllen, etwa bei Umsatz, Mitarbeitern oder Marktkapitalisierung. Zudem werden sie von zwei Analysehäusern unter die Lupe genommen. Diese werden von der Deutschen Börse bezahlt und nicht von den Unternehmen selbst, um Interessenskonflikte zu verhindern. Darüber hinaus müssen sich die Firmen professionell beraten lassen etwa durch Investmentbanken, Wirtschaftsprüfer oder Anwaltskanzleien. Diese sollen der Firma vor, während und nach dem Börsengang zur Seite stehen. Vor dem Börsendebüt müssen sie das Unternehmen nicht nur nach wirtschaftlichen, sondern auch nach rechtlichen Gesichtspunkten durchleuchten. So will die Deutsche Börse verhindern, dass sich Betrugsfälle wie am Neuen Markt wiederholen, wo einzelne Firmen Umsätze frei erfunden und ihre Börsekurse damit in die Höhe getrieben hatten."

296 Deutsche Börse AG (2017), interview with Renata Bandov. 
profit, or the number of employees. In addition, a Deutsche Börse Capital Market Partner must have conducted a financial and legal due diligence of the issuer and confirmed its suitability for Scale.

We can have a look at some of the admission requirements.

The admission requirements consist of three elements. The applicant must:

- fulfil all key admission conditions (such as a market capitalisation of at least of €30 million),

- fulfil at least three of certain five criteria in addition to the key admission conditions, and

- $\quad$ have a Deutsche Börse Capital Market Partner as a co-applicant. ${ }^{297}$

The key admission conditions are as follows:

- Inclusion documents or, if there is a public offer, a valid and approved prospectus.

- A contract with a supporting Deutsche Börse Capital Market Partner.

- At least two years of company history.

- An estimated minimum market capitalisation of $€ 30$ million at the time of the inclusion into trading.

- Par value of at least $€ 1.00$.

- Free float of at least $20 \%$ or at least 1 million shares in free float.

- A research report submitted by a research provider.

In addition, the applicant must fulfil at least three of the following five criteria:

- Minimum turnover of $€ 10$ million.

- Minimum annual earnings of €0.

- Minimum equity capital of $€ 0$.

- Minimum number of employees 20.

- Minimum cumulated equity capital of $€ 5$ million before an IPO.

The application is submitted by the issuer and a Deutsche Börse Capital Market Partner as a co-applicant. A Deutsche Börse Capital Market Partner is a bank or a financial service provider. It must have conducted a financial and legal due diligence of the issuer. The co-applicant vouches for the completeness and accuracy of the statements made in the application and for the completeness of the submitted documents.

297 Deutsche Börse AG’s website. 
In addition to the statutory obligations set out in the Market Abuse Regulation and the German Securities Trading Act, there are ongoing disclosure obligations required by Deutsche Börse AG. ${ }^{298}$

The admission standards clearly exceed the rather open minimum requirements for SME growth markets set out in Article 33(3) of MiFID II.

Some differences between Neuer Markt and Scale. There are interesting differences between these standards and the earlier standards of Neuer Markt. ${ }^{299}$ Scale requires:

- a lower free float (20\% v 25\%)

- a shorter track record (two years $v$ three years)

- a higher market capitalisation (€30 million $\mathrm{v}$ no requirement)

- a higher minimum equity capital in an IPO (minimum cumulated equity capital of $€ 5$ million before an IPO v €1.5 million in net equity capital)

- a lower equity capital without an IPO ( $€ 0 \mathrm{v} € 1.5$ million in net equity capital)

- a smaller issuing of new equity (no issuing $\mathrm{v}$ at least $50 \%$ of the issuer's value in new equity, aggregated market price of the issue at least $€ 5$ million)

- less frequent financial reporting (half-yearly reports $\mathrm{v}$ quarterly reports)

The purpose of designated sponsors on Neuer Markt was to ensure the liquidity and tradability of shares. They had a duty to post price indications or spreads continuously. However, many investors expected them to have a bigger role: "At least some investors wanted them to guarantee fair transactions and a good conduct of the firms they were sponsoring." ${ }^{300}$ This has been addressed on scale with a bank or financial service provider as a co-applicant.

The cases of Neuer Markt and Scale indicate that an SME exchange should exclude start-ups, should not focus on just one sector such as tech, should add sponsoring or mentoring, and should choose a relatively conservative approach.

Private and public venture capital. Ibrahim distinguishes between private venture capital in the US and other countries' public venture capital such as London's Alternative Investment Market (AIM), Germany's Neuer Markt, and Hong Kong's Growth Enterprise Market. According to Ibrahim, "these exchanges are too small to compare to the United States' Nasdaq, and often supply the first growth capital to startups, making Silicon Valley their apt comparison." ${ }^{301}$

298 Deutsche Börse AG’s website.

299 For Neuer Markt, see Harrer H, Erwe P (1998); Vitols S (2001) p 556; Vitols S, Engelhardt L (2005) pp 5-6; Burghof HP, Hunger A (2003); Gilson RJ, Hansmann H, Pargendler M (2011) p 504.

300 Burghof HP, Hunger A (2003).

301 Ibrahim DM (2019) p 1150. 
However, as far as Neuer Markt is concerned, the listed companies were not the kind of companies that would raise venture capital in Silicon Valley. One of the things learnt from Neuer Markt was that there is demand for an SME market rather than a "public venture capital" market. Scale is an SME market.

As regards AIM, SPACs that to some extent could be seen as an alternative to private venture capital seem to prefer the Standard segment of the Official List (section 5.5). ${ }^{302}$ Since SPAC volumes are much greater in the US, the US is the leading country in private venture capital and public venture capital.

\subsubsection{Conclusions}

As regards specialised SME exchanges, one can draw several conclusions from past SME exchange design practices.

First, there should not be overreliance on SME exchanges. An SME exchange can benefit firms and early investors by creating a secondary market for shares. It can also work as a stepping stone for some successful companies that later move to the main market. ${ }^{303}$

Second, the SME exchange should avoid a too narrow technology focus. If the exchange focuses on technology firms, market participants' risk exposure is increased due to the exchange's lack of diversification. There can be hype. When the bubble bursts or valuations otherwise become more realistic, investors may lose trust in the market (Neuer Markt).

Third, the SME exchange is not for start-ups. The issuer should have a history before it can be admitted.

Fourth, listing requirements can be kept relatively simple, if the SME exchange is designed as a secondary market only.

Fifth, the admission criteria should make it possible even for loss-making companies to be admitted, provided that they fulfil minimum requirements as to equity capital. Young companies may need to make losses in their early years in order to develop their technology and build up a customer base (Scale).

Sixth, the inherent illiquidity of SME stocks should be addressed. Different market structures can be chosen to increase liquidity: "One-size-fits-all stock market structures harm SME listings, which are typically less liquid than large cap stocks and require broker-dealers to support liquidity, sales and equity re-

302 Norton Rose Fulbright (2021).

303 Claer Barrett, Aim - 20 years of a few winners and many losers: Why has London's junior market performed so poorly? Financial Times, 19 June 2015. 
search". ${ }^{304}$ One can also use different trading methods to increase liquidity. Early stock exchanges used call auctions. When continuous trading became the norm, ${ }^{305}$ continuous trading was applied to trading in SME stocks as well. It was nevertheless complemented by a market maker requirement, a market capitalisation requirement, or both.

Seventh, there should be lock-ins. It is customary to use lock-ins in venture capital and IPOs. The operating practices to preserve market integrity tend to include "a lock-up period for major shareholders around equity offerings". ${ }^{306}$ Lockins have been used in SME exchange practice as well.

Eighth, there should be a mechanism for the mentoring of SMEs that are contemplating a listing or have just been admitted.

\subsection{Direct Listings and SPACs}

\subsubsection{General Remarks}

Direct listings and SPACs have grown in popularity particularly in the US market. While both avenues have been used to increase listings, they work in fundamentally different ways. Direct listings could be described as an incremental improvement for established firms that need no new equity funding. Since no new equity funding is raised, direct listings do not require underwriters. In principle, SPACs could mean a radical change for young operating firms and provide new business opportunities for established financial firms. ${ }^{307}$ The use of SPACs simplifies both the issuing of shares to the public and the listing of an operating company. But retail investors' costs are high in SPAC investments and there are regulatory concerns.

304 OECD (2015c) p 134.

305 Steil B (2001) p 335: "Every exchange in Western and Central Europe is now using the same basic architecture for its primary trading platform: the continuous electronic auction market, where matching buy and sell order are automatically executed by computer.”

306 OECD (2015c) p 126.

307 The Economist, Leaders. The real revolution on Wall Street, 6 February 2021: "SPACs are a Silicon Valley rebellion against the cost and rigidity of IPOs." 


\subsubsection{Direct Listings in the US}

In the US, equity issuance to public market investors traditionally has followed the firm commitment process with one or more underwriters. ${ }^{308}$ An underwriter requires discounts and commissions. ${ }^{309}$ The cost of listings can be reduced by making direct listings easier.

In a pure direct listing, the company does not issue new shares to the public and therefore foregoes the traditional underwriter. ${ }^{310}$ The absence of an underwriter can make a direct listing cheaper than an IPO. ${ }^{311}$ Moreover, a direct listing does not dilute the holdings of existing shareholders and can be a way to avoid lock-up periods. The downside is higher price volatility when trading opens. ${ }^{312}$ This increases risks for investors. ${ }^{313}$

Silicon Valley bankers and lawyers have been lobbying for direct listings as an alternative to IPOs. ${ }^{314}$ While underwritten IPOs are still expected to remain attractive, ${ }^{315}$ direct listings are regarded as an alternative for cash rich "unicorns". ${ }^{316}$ Such companies seek two advantages: the chance to use their own stock as the consideration in mergers and acquisitions, and the chance for employees to maximise the value of their stock options. ${ }^{317}$

The benchmark is the direct listing of Spotify. The intentions of Spotify were described by Barry McCarthy, Spotify's CFO, in a Financial Times article. Spotify

308 Special Study of Securities Markets (1963a) p 493.

309 Ibid., pp 502-512. See even ibid., pp 501-502 on abuses in pricing. An underwriter may even benefit from the practice of greenshoe that complements the over-allotment of shares. Nelson Smith, The greenshoe option. The Economist, Letters, 29 August 2020.

310 Horton BJ (2019) p 182.

311 Ibid., p 185.

312 Spotify Technology S.A., Form F-1 registration statement filed with the SEC on 28 February 2018, Plan of Distribution: "[U]nlike in an underwritten initial public offering, a DMM in a direct listing may have less information available to it to determine the opening public price of our ordinary shares than a DMM would in an underwritten initial public offering."

313 Ibid.: "[T]he public price of our ordinary shares may be more volatile than in an underwritten initial public offering and could, upon listing on the NYSE, decline significantly and rapidly."

314 Miles Kruppa, SEC opens debate on finding alternatives to IPOs. US markets regulator hears arguments for enabling direct listings to raise capital. Financial Times, 17 October 2019.

315 Denenberg AF, Fausten M, Truesdell RD (2019).

316 See Jaffe MD, Rodgers G, Gutierrez H (2018); Coffee JC Jr (2018); Horton BJ (2019); Mark Baker, Direct listings: the future according to Goldman Sachs. Financial Times, 16 October 2019. 317 See Horton BJ (2019); Coffee JC Jr (2018). 
did not want: the sale of $15 \%$ of the company's market capitalisation at a discount simply to secure a secondary market for the stock; anyone to be subject to a lock-up; hedge funds shorting the stock into the lock-up expiry; or the artificial management of demand and supply that is part of market stabilisation. ${ }^{318}$

The savings seem to come from the fact that a direct listing does not require an underwriter. ${ }^{319}$ Interestingly, the savings do not seem to come from reduced SEC registration obligations. We can have a brief look at the registration obligations.

Direct listings and IPOs are partly covered by different registration obligations. They were summed up by Horton as follows: “(1) The Securities Act registration statement (Form S-1) is used when a company is conducting an IPO. (2) The Securities Act registration statement (Form S-1) may also be used when a person receives shares in a private placement and wants to resell them (which, depending on the timing, the SEC may consider a distribution). In this case, it is referred to as a 'resale registration statement' or 'selling shareholder registration statement.' (3) The Exchange Act registration statement (Form 10) is used when a company is listing shares on an exchange pursuant to Section 12(b) of the Exchange Act of 1934 ... (4) A shortened Exchange Act registration statement (Form 8-A) may be used if a company already filed a Securities Act registration statement (Form S-1)." ${ }^{320}$ There are particular requirements for the direct listing of foreign securities. ${ }^{321}$

For a pure direct listing, the company thus files a Securities Exchange Act of 1934 registration statement only (Form 10). ${ }^{322}$ Form 10 shall be used for registration pursuant to Section 12(b) or (g) of the Exchange Act of classes of securities of issuers for which no other form is prescribed. There is "no inherent statutory obligation to register these shares under the Securities Act of 1933, because the issuer is not making any sale." 323

318 Mark Baker, Direct listings: the future according to Goldman Sachs. Financial Times, 16 October 2019. For the avoidance of lock-ups or a restricted period, see Jaffe MD, Rodgers G, Gutierrez H (2018) and SEC Release No. 34-38067 (Dec. 20, 1996) (Regulation M).

319 Horton BJ (2019) p 191.

320 Ibid., p 190.

321 For the first listing of a Chinese company in New York, see Bergman MS, Borisoff RS, Howson NC (1994).

322 Horton BJ (2019) pp 190 - 191.

323 Coffee JC Jr (2018). 
In practice, however, the SEC may have power over issuers to increase requirements. ${ }^{324}$ A Securities Act of 1933 registration statement (Form S-1) and a Form 8-A registration statement were used in Spotify's direct listing.

Moreover, banks are still required as advisers. First, issuers that want to do a direct listing may need a financial firm to provide a valuation of the shares to be listed. There is a risk of high first-day price swings in direct listings. A designated market maker would need a valuation of the shares before the opening trade. In an IPO, the cover page of the preliminary prospectus would contain a price range of the anticipated sale price. ${ }^{325}$ Second, the NYSE and Nasdaq require an independent, third-party valuation evidencing the market value of publicly held shares. The SEC seems to have made sure that investment banks will be used as advisers when it approved the rule changes of the NYSE and Nasdaq. ${ }^{326}$

\subsubsection{SPACs}

In the 1970s and 1980s, blank cheque companies (BCCs) emerged in the US penny stock market as a vehicle for future takeovers. Because of fraudulent investment schemes and price manipulation, BCCs were regulated by the Penny Stock Reform Act of 1990. The SEC adopted Rule 419 of the Securities Exchange Act that required BCCs to hold a BCC's securities and gross proceeds from the offering in an escrow or trust account until consummation of an acquisition within a certain period of time. ${ }^{327}$

Described as "direct descendents of the corrupt blank check companies that plagued the securities markets", 328 Special Purpose Acquisition Companies (SPACs) have become a popular form of IPOs in the US in recent years. ${ }^{329}$ In fact, the US IPO market largely turned into a SPAC market in 2020-2021. The number of US-listed SPACs was 53\% of all US IPOs in 2020 and 75\% in January-March

324 Horton BJ (2019) pp 190 -191: "While a plain reading of the Exchange Act would seem to indicate that a direct listing could be done relatively simply (by filing a Form 10), the reality is that the SEC used its power over the NYSE to increase what is required. As a result-at least from the perspective of what must be filed-a direct listing is similar to a traditional IPO. The primary differences that remain is that no capital is raised, and that no underwriter is needed."

325 The price range is required by the SEC's rules. See Item 501(b)(3) of Regulation S-K.

326 Horton BJ (2019) pp 200-201.

327 For BCCs and the history of SPACs, see Riemer DS (2007); Heyman DK (2007); Schumacher B (2020); Günther D (2021) Chapter A.

328 Riemer DS (2007) p 932.

329 Generally, see Klausner M, Ohlrogge M, Ruan E (2021); Günther D (2021). 
2021. ${ }^{330}$ This gave The Economist, a newspaper, reason to remark that " $[\mathrm{t}]$ heir sudden popularity and the sheer variety of their size, scope and structure raise the question of which SPACs are sensible and which show signs of mania." ${ }^{331}$ In the past, SPACs seem to have performed poorly because of the "perverse incentives" of SPAC sponsors. ${ }^{332}$ In April 2021, the SPAC market collapsed from the peak level. ${ }^{333}$

There are two main stages in SPAC practice. The first is the SPAC IPO. Since a SPAC is a shell company with no operations, it has little to disclose when it issues shares to investors. This reduces costs. ${ }^{334}$ The second stage is when the SPAC acquires an operating company in a business combination. When the operating company wants to go public through a de-SPAC, it negotiates the terms of a business combination with the SPAC's sponsors. The use of a SPAC as an alternative to a traditional IPO is relatively simple and flexible, because the issuing of shares to investors in an IPO is separated from the operating company going public. The SPAC IPO and the business combination essentially are independent of one another. ${ }^{335}$

In the US, the popularity of SPACs is based on the regulatory framework. First, SPAC practices are de facto constrained by Rule $419 .{ }^{336}$ Rule 419 applies to blank cheque companies but does not apply to SPACs in the strict legal sense. ${ }^{337}$ Market participants comply with much of Rule 419 voluntarily. Voluntary compliance with investor protection rules under Rule 419 has reduced the exposure of SPACs to mandatory regulation, made it possible to differentiate SPACs

330 Data Source: Nasdaq SPAC webpage, citing SPAC Research.

331 The Economist, SPAC invasion, 20 February 2021: "Their sudden popularity and the sheer variety of their size, scope and structure raise the question of which SPACs are sensible and which show signs of mania.” See also Ortenca Aliaj and James Fontanella-Khan, Spac share prices slump as enthusiasm wanes. Financial Times, 2 May 2021.

332 Dimitrova L (2017).

333 Miles Kruppa and Ortanca Aliaj, A reckoning for Spacs: will regulators deflate the boom? Financial Times, 4 May 2021.

334 Günther D (2021) p 33.

335 Klausner M, Ohlrogge M, Ruan E (2021); Coates J (2021).

336 Rule 419(b) on an an escrow or trust account. Rule 419(e)(3) on the release of deposited funds and securities. Rule 419(e)(2)(iv) on the period of 18 months. Rule 419(e)(1) on acquisitions representing at least $80 \%$ of the maximum offering proceeds. Rules 419(e)(2)(ii) and 419(e)(2)(iii) on voting on the business combination. Rule 419(e)(2)(iv) on the returning of funds. Rules 419(c), 419(d), and 419(e)(iv) on disclosures.

337 SEC Release No. 34-51983 (September 12, 2005) (Amendments to the Penny Stock Rules) and Rule $3 \mathrm{a} 51-1(\mathrm{~g})(1)$ stating that a stock is not a penny stock where an issuer that has been in continuous operation for less than three years has net tangible assets in excess of $\$ 5$ million. Rule 501(a) on a \$5 million threshold for "accredited investors". 
from blank check offerings under Rule 419 when necessary, and reduced legal risk. Second, SPAC practices are fostered by de facto standardisation, since market participants adapt to the regulatory framework in similar ways. SPAC practices are to some extent different from Rule 419 requirements. ${ }^{338}$ Third, SPAC practices are fostered by the beneficial treatment of emerging growth companies under the JOBS Act. ${ }^{339}$ The UK Listing Review described the resulting SPAC IPO practices as follows: "SPACs typically file as Emerging Growth Companies using provisions that allow for confidential filings. They also use an exemption to SEC rules for issuers with less than three years of operations who have a minimum of $\$ 5$ million in net assets. At the point of listing, the SPAC cannot have selected a target acquisition (or it would have to provide disclosure regarding the target)." 340

Moreover, exchange rules play an important role. SPAC shares used to be traded exclusively on the AMEX and the OTC Bulletin Board. Since 2008, SPAC shares are listed on the NYSE and Nasdaq. ${ }^{341}$ Of the three distinctive tiers of the Nasdaq Stock Market, Nasdaq Capital Market has the least stringent initial listing requirements. ${ }^{342}$ Since Nasdaq's slightly less stringent listing standards gave it a competitive advantage, the NYSE changed its rules accordingly. Both therefore apply similar rules. ${ }^{343}$

338 See Heyman DK (2007) pp 541-543.

339 For emerging growth companies, see Title I of the JOBS Act.

340 Hill J (2021) section 13.2 pp 82-83. For confidentiality, see SEC Division of Corporation Finance, JOBS Act FAQs: Confidential Submission Process for Emerging Growth Companies (revised December 21, 2015); Latham \& Watkins LLP (2020) p 6: “Confidential submission offers a number of advantages: If you decide not to proceed with the IPO past this stage, competitively sensitive information ... will not have been made public."

341 Lakicevic M, Shachmurove Y, Vulanovic M (2014). AMEX was acquired by NYSE Euronext in 2008.

342 According to the "Financial and Liquidity Requirements" of Nasdaq Capital Market, companies must meet all of the criteria under at least one of three standards, namely the "Equity Standard", the "Market Value of Listed Securities Standard", or the "Net Income Standard". All require 300 unrestricted round lot shareholders, 1 million unrestricted publicly held shares, and a certain bid price or closing price. Unlike the other standards, the "Market Value of Listed Securities Standard" requires neither operating history nor net income from operations. Instead, the market value of listed securities must be at least $\$ 50$ million and the market value of unrestricted publicly held shares must be at least $\$ 15$ million.

343 Hill J (2021) section 13.2.2 pp 83-84; Günther D (2021) p 22; Nasdaq Rule IM-5101-2 and Section 102.06 of NYSE Listed Company Manual. 
SPAC IPOs are possible even in Europe. In fact, the regulation of SPACs in Europe is perceived as more flexible than regulation in the US. ${ }^{344}$ Of SPACs listed in Europe, most have been listed on the London Stock Exchange. ${ }^{345}$ This said, most "European" SPACs were listed in the US in 2020. ${ }^{346}$ There is one-way traffic. An overseas listing would make it more difficult for US investors to trade in the SPAC's shares. ${ }^{347}$ Generally, many US-listed emerging growth companies are foreign. $^{348}$

In Europe, SPACs took off first in the UK. SPACs are considered cash shells which are not eligible for listing on the Premium segment of the Official List of the London Stock Exchange. ${ }^{349}$ The favoured UK listing venue for SPACs is the Standard segment of the Official List with less strict listing requirements. A listing on the AIM market of the LSE would be possible, but SPACs tend to prefer the Standard segment. One of the reasons is the AIM requirement that reverse takeovers must be approved by shareholders and the absence of this requirement on the Standard segment. ${ }^{350}$

Sponsors. SPACs are companies formed to raise capital in an IPO with the purpose of using the proceeds to acquire one or more unspecified businesses or assets to be identified after the IPO. ${ }^{351}$ Cash raised through the IPO of the SPAC is placed in trust for a future acquisition. The sponsors of the SPAC will find a target company for a business combination. The successor company is a listed operating company.

A SPAC is founded by sponsors that may range from industry insiders to celebrities. While celebrities commercialise their fame, SPAC IPOs could enable

344 For example, Ignatyeva E, Rauch C, Wahrenburg M (2013); Schumacher B (2020) p 404: “A notable difference between European SPACs and American SPACs is that European SPACs tend to have more flexible regulations and tend to not subject the management to as many stringent requirements."

345 Günther D (2021) pp 23-25; Ignatyeva E, Rauch C, Wahrenburg M (2013).

346 Nikou Asgari and Stephen Morris, European bankers set sights on Amsterdam as regional Spac capital. Financial Times, 17 February 2021; Munter P (2021).

347 Heyman DK (2007) pp 551-552 on AIM as an alternative just before the financial crisis: "[A]lthough a few SPACs have been done on the AIM, large scale movement to that self-regulated market is unlikely ... IPO shares may be sold in the U.S. only to qualified institutional buyers, and such shares are not freely tradable by these U.S. buyers on the AIM; they must be held for a period of one year or more under most circumstances."

348 Morrison \& Foerster LLP (2017).

349 See Norton Rose Fulbright (2021). See also Hill J (2021) Recommendations overview, p 15, number 10: "Maintain the three-year track record requirement for the premium listing segment." 350 Norton Rose Fulbright (2021).

351 See Layne R, Lenahan B (2018). 
well-known industry insiders to benefit from their good reputation and industry knowledge.

Sponsors obtain a "promote". The sponsor promote means greater equity than their cash contribution or commitment would otherwise imply. Since sponsors that are industry insiders control both the SPAC IPO and negotiate the terms of the business combination, they can ensure favourable terms. Sponsors could end up with a $20 \%$ stake in the SPAC, meaning $25 \%$ of the IPO proceeds. ${ }^{352}$ However, their promote is at risk. In the US, the sponsor promote is forfeited and the SPAC liquidates in the absence of a business combination within a period of two years. ${ }^{353}$

Sponsors' incentives create conflicts of interest. If a business combination deal is made, the $20 \%$ share of the founders becomes very valuable. If the SPAC liquidates without having completed an acquisition, the shares and warrants owned by the sponsors end up worthless. ${ }^{354}$ Sponsors therefore have strong incentives to make a deal regardless of whether it is good or bad for other investors. ${ }^{355}$

Sponsors' incentives have contributed to poor SPAC performance in the past. A study found "strong evidence that much of SPAC value destruction through bad acquisitions is a result of certain contractual features that give SPAC managers incentives to pursue any acquisition over no acquisition." 356 According to the study, performance is worse with increasing SPAC sponsors' ownership, when deals are completed just before the contractually specified deadline for a SPAC acquisition, or when the deal just barely meets the contractually specified minimum transaction value. ${ }^{357}$

Since SPACs usually are founded by industry insiders, sponsors may have conflicts of interest in their other capacities. ${ }^{358}$ For example, a SPAC may be founded by a private equity firm that manages other people's money and raises income in two capacities. On one hand, it looks for a profitable exit as the manager of a private equity fund. On the other, it looks for a takeover target as a SPAC

352 Dimitrova L (2017) p 102; Norton Rose Fulbright (2021); Klausner M, Ohlrogge M, Ruan E (2021).

353 Coates J (2021).

354 Dimitrova L (2017) p 102.

355 "If you put a gun to my head and said you have to buy a business in two years, I'd buy one but it wouldn't be much of one.” Warren Buffett according to Eric Platt, Warren Buffett sees 'significant' inflation amid 'red hot' US recovery. Financial Times. 2 May 2021.

356 Dimitrova L (2017) p 99.

357 Ibid., pp 99-100.

358 Norton Rose Fulbright (2021). 
sponsor that has unilaterally chosen its own sponsor promote. This increases their liability risks under securities law. ${ }^{359}$ In the US, the separation of the SPAC IPO and the de-SPAC business combination means that the de-SPAC business combination does not benefit from the safe harbour under the Private Securities Litigation Reform Act. ${ }^{360}$

Underwriters. In a SPAC IPO, securities are sold to investors through a conventional underwriting. Underwriters earn fees. Millstream Acquisition Corp., the first modern SPAC that went public in 2003 after the dotcom bubble, was an invention of its underwriter, the investment bank EarlyBirdCapital. SPACs have been described as "fee-driven". ${ }^{361}$ According to a law firm, the typical underwriting fee for a SPAC in the US is 5.5\% of the IPO proceeds, with $2 \%$ paid in cash at the closing of the IPO and 3.5\% paid when the business combination closes. In the London market, a typical underwriting fee is around $2-3 \%$ on the proceeds from shares in the IPO, excluding those subscribed for by the sponsor, payable on completion of the IPO. In the Frankfurt and Amsterdam markets, underwriting fees are between US and London levels. ${ }^{362}$ According to a study, SPAC performance is worse when SPAC IPO underwriter fees are deferred and paid upon a SPAC's successful merger completion. ${ }^{363}$

Investors. There must be investors. In a SPAC IPO, redeemable shares are primarily sold for cash to hedge funds and other institutions. Initial investors also commonly obtain warrants to buy additional stock at a fixed price. ${ }^{364}$

For investors, the SPAC is a blank check. ${ }^{365}$ Investors rely on the reputation of SPAC sponsors. But investors participate for various reasons and rely on the reputation of SPAC sponsors in different ways.

359 Coates J (2021): “Indeed, in some ways, liability risks for those involved are higher, not lower, than in conventional IPOs, due in particular to the potential conflicts of interest in the SPAC structure ... SPAC sponsors and targets should already be hearing from their legal, accounting, and financial advisors that a de-SPAC transaction gives no one a free pass for material misstatements or omissions."

360 Ibid.

361 "I call it fee-driven buying. In other words, they're not buying because it's a good investment. They're buying it because the adviser gets a fee. And of course, the more of that you get, the sillier your civilisation is getting." Charlie Munger according to Eric Platt, Warren Buffett sees 'significant' inflation amid 'red hot' US recovery. Financial Times. 2 May 2021.

362 Freshfields Bruckhaus Deringer LLP (2021). See also Heyman DK (2007) p 546: "For the investment banks, the lure of the SPAC is simply that it generates a healthy fee." For the evolution of fees, see Lakicevic M, Shachmurove Y, Vulanovic M (2014).

363 Dimitrova L (2017) pp 99-100.

364 Heyman DK (2007) p 548; Coates J (2021).

365 For the difference between a "blank cheque" and a "blind pool" offering, see Heyman DK (2007) p 534. 
First, investors may turn to SPACs because of the lack of alternatives: "There is no magic to it ... There's just a lot of money out there looking for a home."366 According to a law firm, "SPACs are particularly attractive to financial institutions looking to deploy capital in the current climate due to the combination of the low interest rate environment and high market valuations." 367

Second, early investors often redeem or sell their shares around the time of the business combination. ${ }^{368}$ They may therefore try to profit from later investors' scarce investment alternatives and later investors' reliance on the reputation of SPAC sponsors. Later investors buy shares in the aftermarket or participate in a new offering by the combined entity in the course of the de-SPAC.

Third, SPACs could allow investors to co-invest with sponsors perceived as having the requisite industry knowledge and expertise. ${ }^{369}$

Fourth, SPACs could enable some investors to participate at an earlier stage than would have been possible otherwise. The SPAC route could open up earlystage investing and private placements in growth companies for retail investors. ${ }^{370}$ A traditional operating-company-IPO would mean a later-stage investment for retail investors.

Fifth, SPACs could provide a functional equivalent to the pooling of private investments. This is because of the separation of the SPAC IPO (in which investments are made in a takeover vehicle) and the de-SPAC (in which the vehicle uses the monies to fund a private investment). While many wealthy investors already can make investments in private equity or venture capital funds whose managers choose portfolio companies, a SPAC IPO can enable even retail investors to participate in acquisitions. ${ }^{371}$ This said, SPACs and de-SPACs cannot be seen as a functional alternative to private equity or venture capital from the perspective of retail investors and the operating company. The de-SPAC transaction will be structured in a different way (private equity takeovers are leveraged buyouts), the ancillary services of sponsors and fund managers are different (venture capital fund managers provide important ancillary services to portfolio companies), and the incentives of fund managers and SPAC sponsors are different (fund managers are remunerated on the basis of managed capital and returns).

366 An unnamed banker. Arash Massoudi and Ortenca Aliaj, 'Blank-cheque' blitz: Michael Klein leads Wall St charge into Spacs. Financial Times, 21 July 2020.

367 Norton Rose Fulbright (2021).

368 Coates J (2021).

369 Norton Rose Fulbright (2021).

370 Heyman DK (2007) pp 548-549.

371 Ibid. 
Investors' costs are indirectly increased by underwriting fees payable by the SPAC. They are directly increased by the sponsor promote that may substantially dilute their share ownership. ${ }^{372}$ Moreover, their share ownership may be diluted when the de-SPAC business combination is preceded by a PIPE, when the shareholders of the operating company are allocated a large share of the combined entity in the course of the de-SPAC, and when shares are allocated as an incentive to the managers of the combined entity.

Operating company. After the SPAC IPO, sponsors try to find an operating company for the de-SPAC. For operating privately-held companies, SPACs are marketed as an alternative to an IPO. ${ }^{373}$ The functional alternative to an IPO is the de-SPAC process that leads to a business combination. ${ }^{374}$

A de-SPAC business combination can bring several benefits to the operating privately-held company and/or its shareholders. ${ }^{375}$ First, listing through a business combination with a SPAC is a quick and simple way to a public listing. Second, SPACs are perceived as attractive buyers due to the private negotiation of terms, price certainty, and the potential for higher valuations. ${ }^{376}$ Third, SPACs could help SMEs that either have no access to a traditional IPO or to venture capital. After the dotcom boom, they helped young growth firms. ${ }^{377}$ They might now be used to help fund the development of technologies that require long-term investment. ${ }^{378}$ Fourth, foreign companies have used SPACs to obtain a listing in the US. ${ }^{379}$

372 Klausner M, Ohlrogge M, Ruan E (2021).

373 Arash Massoudi and Ortenca Aliaj, 'Blank-cheque' blitz: Michael Klein leads Wall St charge into Spacs. Financial Times, 21 July 2020 citing Anu Aiyengar, co-head of global M\&A for JPMorgan Chase: “'Spacs are reaching out to pre-IPO companies and saying they should view this as a safer way to go public and a credible alternative to an IPO'." See also James Fonatella-Khan, Ortenca Aliaj and Sara Germano, Liverpool FC owner looks at stock market listing. Financial Times, 10 October 2020.

374 For example, a de-SPAC business combination was used by the lorry start-up Nikola. First there was VectoIQ Acquisition, a blank check company. VectoIQ raised \$200 million in a May 2018 IPO and was listed on the Nasdaq under the symbol VTIQ. This SPAC focused on the smart transportation industry. In March 2020, it agreed to merge with Nikola Corp at an implied enterprise value of about $\$ 3.3$ billion, having secured a $\$ 525$ million private placement led by Fidelity. On 4 June 2020, the company began trading on the Nasdaq under its new ticker NKLA. See The Economist, Partying like it's 1999, 22 August 2020.

375 Heyman DK (2007) p 547.

376 Norton Rose Fulbright (2021).

377 Günther D (2021) p 14.

378 The Economist, Rain for the rainmakers: The SPAC craze will change tech investing, 20 February 2020.

379 Heyman DK (2007) p 551. 
Further participants include the managers of the operating company. It is not unusual to use share-based management incentives. In this way, managers of the operating company are given a financial incentive to make the business combination happen. ${ }^{380}$

Convergence of practices. According to a law firm, US and European markets use the same basic SPAC structures. In the US, Amsterdam (Euronext) and Frankfurt (Deutsche Börse) markets, "investors buy units consisting of shares and a fraction of a warrant, the sponsor obtains a near-free promote and contributes some at-risk capital, the IPO proceeds go into trust, the SPAC has up to 24 months to find an acquisition target in a specified sector, SPAC shareholders must approve the business combination, and SPAC shareholders have the right to redeem their shares at the time of the business combination". ${ }^{381}$

In continental Europe, the model is US SPACs. Neither EU company law nor Member States' company laws seem to prevent the adoption of similar practices. $^{382}$

A law firm identified some differences between US SPACs and UK SPACs at the time of the initial business combination. ${ }^{383}$ They relate to the following issues: the decision rights of shareholders; the suspension of trading; shareholders' redemption rights; limits on the market value of the initial business combination; and the underwriting fee.

In the US, shareholder approval usually is required to approve the acquisition, ${ }^{384}$ but since no shareholder approval is required in the case of an issuer listed on the Standard segment in the UK, an acquisition by a UK SPAC can be closed more quickly. In the US, shareholders of the SPAC typically are granted redemption rights. ${ }^{385}$ The UK Listing Review recommended the introduction of redemption rights. ${ }^{386}$ Under both the NYSE and Nasdaq rules, the SPAC must complete one or more business combinations that have a fair market value equal to at least $80 \%$ of the trust account at the time of the initial business combination, ${ }^{387}$ but there are no such requirements in the UK. In the US, it is customary to use a deferred underwriting fee, with a portion of the fee paid at the clos-

380 Günther D (2021) p 20.

381 Freshfields Bruckhaus Deringer LLP (2021). For a more detailed description of the life-cycle of the SPAC, see Klausner M, Ohlrogge M, Ruan E (2021).

382 Freshfields Bruckhaus Deringer LLP (2021).

383 Norton Rose Fulbright (2021).

384 See also Hill J (2021) section 13.2.2 p 84.

385 Ibid.

386 Ibid., Recommendations overview, p 12, number 6.

387 See also ibid., section 13.2.2 p 83. 
ing of the IPO and the remainder deferred until the closing of the initial acquisition. Moreover, the ongoing listing requirements and annual and periodic filing requirements are considered to be more burdensome for US-listed companies than for companies listed on the Standard segment or AIM.

There could be some differences between US SPACs and European SPACs. European SPAC practices are influenced by existing EU law in the Member States or, in the post-Brexit UK, national law that still reflects the legacy of its past EU membership. For example, board practices could be influenced by the choice of company form and company law. ${ }^{388}$ We can have a brief look at particular aspects of SPACs from a European perspective.

Particular aspects from a European perspective. A SPAC is a shell company. ${ }^{389}$ It is not a fund. But it could be seen at least as a functional equivalent to a "collective investment undertaking". The question therefore is whether a SPAC can fall within the scope of the Alternative Investment Fund Managers Directive (AIFMD). The answer may depend on whether the SPAC is regarded as a "collective investment undertaking", ${ }^{390}$ whether it is regarded as having a "defined investment policy" for the benefit of its investors, ${ }^{391}$ or whether it is regarded as having a "general commercial or industrial purpose". ${ }^{392}$ The SPAC's investment strategy is described in its IPO prospectus or admission document.

Generally, SPAC practices are constrained by the applicable company laws, securities laws, and laws governing financial services. In the absence of any particular SPAC rules in EU law, SPACs are regulated on a piece-meal basis under existing EU law. The legal framework varies depending on the Member State.

The founders may choose where to incorporate the SPAC. For example, a SPAC listed on the Frankfurt Stock Exchange can be incorporated in another country such as Luxembourg and benefit from the flexibility of Luxembourg company law. ${ }^{393}$ Moreover, the founders may choose the company form. For example, Dutch SPACs can be listed as Dutch NVs (which customarily are used for listed companies) or BVs (which customarily are used for privately-held companies). This increases the flexibility of the Dutch legal framework for SPACs. ${ }^{394}$ Generally, the choice of the country of incorporation and the company form is

388 See even Freshfields Bruckhaus Deringer LLP (2021).

389 SEC Division of Corporation Finance, Staff Statement on Select Issues Pertaining to Special Purpose Acquisition Companies (March 31, 2021).

390 Point (a) of Article 4(1) of Directive 2011/61/EU (AIFMD).

391 Point (a)(1) of Article 4(1) of Directive 2011/61/EU (AIFMD).

392 See ESMA, Guidelines on key concepts of the AIFMD, ESMA/2013/611, 13 August 2013.

393 In the EU, Article 54 of the TFEU applies.

394 Freshfields Bruckhaus Deringer LLP (2021). 
a commercial decision. The choice must ensure flexibility in the light of the fact that the country and form of the future business combination are still unknown. For US SPACs, the preferred jurisdictions include British Virgin Islands, New York, and Delaware. Incorporation in the UK or Luxembourg or the choice of an SE have been popular in the EU. ${ }^{395}$

The legal framework will also depend on exchange rules. An exchange applies its general rules as default rules with certain exceptions for SPACs. This can be illustrated with the Frankfurt Stock Exchange and the Nordic markets of Nasdaq.

Before a company's shares are eligible for admission on the Frankfurt Stock Exchange, the company "must have existed as a company for at least three years and have disclosed its financial statements for the three financial years preceding the application" under the general rules. ${ }^{396}$ But as this usually is not the case with a SPAC, Deutsche Börse will allow the shares to be admitted, "if it is in the interest of the issuer and the public to do so". ${ }^{397}$ This reflects the provisions of the Listing Directive. ${ }^{398}$ The management board of Deutsche Börse will use its discretion when making the decision. ${ }^{399}$ For this reason, SPACs can be listed on the Regulated Market of the Frankfurt Stock Exchange (General Standard and Prime Standard).

As regards Nasdaq's Nordic main markets, there are similar exceptions. The customary admission requirements regarding historical financial information, business operations, and operating history are not applicable, because the SPAC in many aspects will be an empty shell with very limited business operations at the time of listing. Other than this, the customary listing process applies. ${ }^{400}$ The prospectus requirement is based on the Prospectus Regulation,

395 Günther D (2021) p 32.

396 Deutsche Börse website, referring to section 3(1) BörsZulV.

397 Deutsche Börse website, referring to section 3(2) BörsZulV.

398 Article 44 of Directive 2001/34/EC (Listing Directive).

399 Deutsche Börse website: "For the admission of SPACs, the Frankfurt Stock Exchange has hitherto exercised its discretion in individual cases and decided in favour of admission to the Regulated Market if all of the following conditions were met: The proceeds of the issue is paid into an interest-bearing escrow account. The intended use of the proceeds of the issue is detailed in the prospectus. The SPAC provides evidence that its existence will be limited to a fixed period of time and that in the event of its liquidation, the assets in the escrow account will be returned to the investors, and it is ensured that the use of the assets in trust is decided with a shareholder majority of at least 50 per cent.”

400 Nasdaq Nordic Main Market Q\&A on SPAC listings: Questions and Answers on the admission requirements, the admission process and disclosure requirements for SPAC:s and the Business Combination. Version 3. Last update: 3 March 2021. 
but Nasdaq recommends the publication of more extensive information. ${ }^{401}$ One may note that there is an EU Growth Prospectus for SMEs. ${ }^{402}$

There are requirements as to the distribution of shares to the public (free float requirements). In the EU, a $25 \%$ free float rule for issuers that seek admission of securities for trading on a regulated market is based on the Listing Directive and to some extent MiFID II. ${ }^{403}$ The UK Listing Review recommended lowering the free float requirement from $25 \%$ to $15 \%$ as the earlier requirement was not regarded as necessary to ensure liquidity. On the NYSE and Nasdaq, liquidity is ensured by requiring a number of round lot shareholders upon listing and after listing. ${ }^{404}$ But on Nasdaq's Nordic markets, the European 25\% rule applies. $^{405}$

The main ways to protect investors include constraints on the use of assets, various mechanisms that make it easier for investors to get their money back, bankruptcy remoteness, sponsors, and the right of investors to vote on the business combination.

In SPAC practice, the use of monies raised through the SPAC IPO is limited to the business combination. Monies will be returned to investors unless a business combination is completed within the specified timeframe, that is, in the absence of timely “de-SPACing”. Unless shareholders grant an extension, the SPAC will be

401 Ibid., section 2.4: "The Exchange deems transparency in relation to the areas listed below to be important for investors to ensure fair and orderly trading and a reliable price formation process of the Share of the SPAC. Thus, the Exchange expects the Issuer to include detailed information on each area listed below in the Prospectus. - The objective, timeline and purpose of the SPAC. - The redemption process and terms. - Information on the sponsor, the sponsor's strategy and the reasoning behind the sponsor's decision to sponsor the SPAC (including information about any fees or other rewards to the sponsor and/or other setups of beneficial nature for the sponsor)."

402 Article 15 of Regulation 2017/1129 (Prospectus Regulation) on the preferential treatment of SMEs and the EU Growth Prospectus.

403 Article 48 of Directive 2001/34/EC (Listing Directive); Article 51 of Directive 2014/65/EU (MiFID II); Article 2 of Commission Delegated Regulation (EU) 2017/568 supplementing Directive 2014/65/EU of the European Parliament and of the Council with regard to regulatory technical standards for the admission of financial instruments to trading on regulated markets.

404 Hill J (2021) section 2.3 and Chapter 9; SEC Release No. 34-90245 (October 22, 2020) (The Nasdaq Stock Market LLC; Notice of Filing of Proposed Rule Change), I: "Nasdaq's listing requirements include a number of criteria designed to ensure that a listed security has adequate liquidity ... Among these is the requirement for a company to have a minimum number of publicly held shares, market value of publicly held shares and round lot holders in order to list a security on the Exchange."

405 Nasdaq (2021) section 2.3: "The SPAC should, as a general rule, satisfy the $25 \%$ free float requirement ..." 
liquidated and investors reimbursed at the IPO offering price and before the founders. ${ }^{406}$

On one hand, the timeframe and the potential right to get the money back create a cap that reduces investors' risks in relation to their capital investment. On the other, they also increase the risk of poor returns, since the liquidation of the SPAC will not create a profit. The risk exposure of an individual investor is increased by the right of each shareholder to vote on the business combination. The timeframe, investors' rights, and sponsors' own exposure may also give sponsors incentives to "proceed with the acquisition of a less than ideal target company or on less than optimal terms". ${ }^{407}$ For this reason, the inherent quality of sponsors should be paramount for investors.

In SPAC practice, the initial investment that covers operational costs and initial business combination costs is provided by sponsors. It is complemented by interest earned on the monies raised. ${ }^{408}$ The securities of founders typically are locked-up for a certain period of time following the initial acquisition in order to better align the interests of sponsors with those of investors and to reduce investors' perceived risk exposure. Moreover, founders customarily serve as board members of the SPAC. ${ }^{409}$ In relation to investors, sponsors thus provide important services.

For their services, sponsors are rewarded with a block of shares the size of which exceeds their share of the capital investment. Sponsors might invest about $2.5 \%$ of the funds held by the SPAC. The sponsor promote might be up to $20 \%$ of the SPAC's share capital and voting rights. ${ }^{410}$ In the EU, the sponsors would need to take into account the existence of mandatory bid rules under the governing law. ${ }^{411}$

To ensure that monies can be repaid to investors, they must be kept separate from the assets of sponsors and the other assets of the SPAC and must only be released for purposes of the completion of the initial business combination or, failing that, the liquidation of the SPAC. In common law countries, monies raised through the SPAC IPO can be held in a trust account or in escrow. In the US, "90 per cent of the gross proceeds raised during the IPO must immediately be depos-

\footnotetext{
406 Winston \& Strawn LLP (2021).

407 Norton Rose Fulbright (2021).

408 Ibid.; Günther D (2021) p 31.

409 Norton Rose Fulbright (2021).

410 Freshfields Bruckhaus Deringer LLP (2021); Winston \& Strawn LLP (2021).

411 See, for example, Article 5(1) of Directive 2004/25/EC (Directive on takeover bids).
} 
ited and held in a trust account and are subject to strict investment criteria”. ${ }^{412}$ An escrow account is used in civil law countries. ${ }^{413}$

Moreover, it is customary to use both shares and warrants. ${ }^{414}$ In SPAC practice, the securities offered in the IPO are units that consist of a common share (that is, an ordinary share) and a warrant to common shares. Warrants grant investors the right to acquire additional shares of the company at a specified point in the future at the warrant strike price. ${ }^{415}$ All warrants are issued to shareholders as part of the unit when the IPO closes. In Amsterdam, part of the warrants have been issued to shareholders when the de-SPAC business combination closes. ${ }^{416}$ Shares and warrants can be traded separately after listing. The use of warrants means that investors pay less money up front and less money needs to be repaid to investors in the event that the business combination will not happen. Moreover, they are protected against dilution where the warrants may not be exercised before the business combination. ${ }^{417}$

To ensure that monies are repaid to investors before they are repaid to sponsors, sponsors subscribe for preferred shares (also known as "founder shares") and warrants that give a right to common shares. When the initial business combination is completed, their preferred shares are converted into common shares. ${ }^{418}$ To reward sponsors, founder shares entitle founders to additional benefits. $^{419}$

Before the initial business combination, investors can sell the SPAC's listed stocks and warrants. After the initial business combination, they may sell their shares. Depending on the governing law, investors may have a right to ask for a share buyback at the IPO offering price or a right of redemption where investors do not wish to support the proposed initial business combination. Interests in the SPAC therefore are relatively liquid securities. ${ }^{420}$

The founders try to find a target for the business combination. Since acquisitions can take many forms, the acquisition process must depend on the case. If

412 Hill J (2021) section 13.2.2 p 83.

413 Freshfields Bruckhaus Deringer LLP (2021).

414 See, for example, Coates J, Munter P (2021); Freshfields Bruckhaus Deringer LLP (2021).

415 Norton Rose Fulbright (2021): "usually a 15 per cent mark-up of the IPO share price”.

416 Freshfields Bruckhaus Deringer LLP (2021).

417 Heyman DK (2007) p 542.

418 Winston \& Strawn LLP (2021).

419 Norton Rose Fulbright (2021): "Founder shares typically entitle founders to a certain percentage of the upside in the value of the company following the acquisition, usually 20 per cent, once the share price reaches a certain hurdle for a designated number of consecutive trading days, typically set at 15 per cent above the IPO price.”

420 Winston \& Strawn LLP (2021); Norton Rose Fulbright (2021). 
the target is large, the acquisition will be a reverse takeover. The SPAC might even take on additional debt or raise additional equity through a private investment in public equity (PIPE) to fund the acquisition. Equity financing may have a dilutive effect on existing shareholders. ${ }^{421}$

It is customary to require shareholder approval for the proposed business combination. In the EU, this would in practice be required by provisions of company law implementing Directive (EU) 2017/1132. ${ }^{422}$ Shareholders' voting rights in business combinations largely reflect the European legal capital regime. ${ }^{423}$ In the US, Rule 419 ensured that the process of making an acquisition could not be done hastily. Rule 419 requires the approval of $80 \%$ of the shareholders. At the same time, it gives shareholders a right of rescission. ${ }^{424}$ The required shareholder approval has sometimes meant that investors have blocked a deal they have not liked and got their money back. For example, the SPAC market was wiped out when this happened during the financial crisis of 2007-2009. ${ }^{425}$

Moreover, shareholder approval may be a requirement under the applicable listing rules. For example, there is an AIM requirement that reverse takeovers must be approved by shareholders but no such requirement for companies with a listing on the Standard segment. ${ }^{426}$

In SPAC practice, shareholders may have redemption rights in the context of the business combination. Whether they may ask for the redemption of their shares may or may not depend on whether they have voted against the business combination. ${ }^{427}$ In Europe, there are statutory company law constraints on the redemption of shares. ${ }^{428}$ The legal capital regime will generally influence the choice of the country of incorporation and the company form. For example, German founders might choose to incorporate an SE in Luxembourg. ${ }^{429}$

SPACs may acquire more than one target. There is a target size restriction in the US but not in Europe. In the US, the initial business combination must be

421 Norton Rose Fulbright (2021).

422 See, for example, Articles 68(1) and 93(1) of Directive (EU) 2017/1132 (Directive relating to certain aspects of company law).

423 Mäntysaari P (2010c) sections 5.3-5.4.

424 Riemer DS (2007) p 943.

425 Heyman DK (2007) p 550; Günther D (2021) p 15.

426 Norton Rose Fulbright (2021).

427 Freshfields Bruckhaus Deringer LLP (2021).

428 See Articles 78 and 82 of Directive (EU) 2017/1132 (Directive relating to certain aspects of company law).

429 Günther D (2021) p 26: "Eine Gründung in einer deutschen Rechtsform ist bislang noch nicht erfolgt und steht de lege lata in Konflikt mit dem Kapitalaufbringungs- und Kapitalerhaltungsvorschriften und der strengen Kompetenzverteilung in der AG.” 
with one or more businesses having an aggregate fair market value of at least 80 percent of the value of the SPAC's trust account. ${ }^{430}$ There is no $80 \%$ rule in Frankfurt, Amsterdam or London. ${ }^{431}$

In the UK, a rule regarding trading suspension following the identification by the SPAC of an acquisition target is seen as a key deterrent for potential investors: "It exposes investors to the possibility that they will be 'locked into' their investment for an uncertain period ... even if they wish to exit - due to differences of view over the target or for other reasons." ${ }^{432}$

\subsubsection{Conclusions}

Experiences with direct listings and SPACs show that there are ways to reduce operating companies' listing costs through incremental improvement and radical innovation. Direct listings cut costs by cutting out the underwriters. SPACs are a way to simplify regulatory compliance by a new middlemen. The issuing of shares to the public is simple, because the issuer is an empty shell and has little to report. The raising of capital by the operating company and listing its shares are simple, because the operating company negotiates a reverse takeover or another business combination directly with the SPAC's sponsors. However, retail investors have lost money in SPAC IPOs in the past.

Both direct listings and de-SPACs can increase the number of operating companies with publicly-traded shares. Direct listings are less problematic for retail investors. While SPAC IPOs seem to be a poor deal for retail investors, increasing the number of companies with publicly-traded shares through de-SPAC business combinations is in the interests of retail investors.

\subsection{Retail Investor Empowerment through Social Media and Broker-Dealer Competition}

\subsubsection{General Remarks}

Retail investors' access to trading has been improved by the emergence of lowcost online brokerage platforms. Their access to information has been improved

430 Hill J (2021) section 13.2.2 p 83; Freshfields Bruckhaus Deringer LLP (2021).

431 Freshfields Bruckhaus Deringer LLP (2021).

432 Hill J (2021) section 2.4 p 30. 
by social media. Both are in the process of changing stock markets. The current trends can be illustrated with the GameStop case (section 5.6.2) and the integration of social media and trading (section 5.6.3).

\subsubsection{The GameStop Case}

The GameStop case started when some Reddit traders discussed the undervaluation of GameStop in the US stock market. They believed that it was possible to play against short-selling hedge funds by buying GameStop stocks and call options. Retail investors typically buy "naked" call options, that is, call options without a hedge. 433

In January 2021, the Reddit message board and its r/WallStreetBets community had managed to put GameStop in the limelight. There was a buying spree that sparked a "short squeeze". ${ }^{434}$ Significant volumes of unhedged call options generally force marketmakers to buy up shares in the underlying stocks, creating a positive feedback loop. ${ }^{435}$ This is what happened in the GameStop case as well.

The case raised questions about market manipulation ${ }^{436}$ and the role of broker-dealers. Broker-dealers were affected because of clearinghouse requirements. Since the settlement date was $\mathrm{T}+2$, trades stayed on the books of the broker. The clearinghouse therefore required a significant amount of capital from the brokers. To cope, Robinhood and other platforms decided to halt buy orders and leveraged trading in so-called "meme stocks". ${ }^{437}$ Without Robinhood investors' ability to purchase additional shares of GameStop, WallStreetBets could not continue with the short squeeze and the stock price collapsed.

The GameStop case indicated that retail investors can have a voice. The case was perceived as "a game stopper". Because of this new kind of phenomenon, the House Financial Services Committee held a hearing dubbed "Game Stopped? Who Wins and Loses When Short Sellers, Social Media, and Retail Investors Collide".

433 The Economist, Techtonic shifts, 12 September 2020.

434 Ian Smith and Robin Wigglesworth, GameStop's wild ride: how Reddit traders sparked a 'short squeeze'. Financial Times, 29 January 2021; Bautz JF (2021).

435 The Economist, Techtonic shifts, 12 September 2020.

436 SEC, Statement of Acting Chair Lee and Commissioners Peirce, Roisman, and Crenshaw Regarding Recent Market Volatility (January 29, 2021). See also Bautz JF (2021); Napps EA (2021); Smerznak I (2021). For predatory trading in financial economics, see Brunnermeier MK, Pedersen LH (2005).

437 Bautz JF (2021); Napps EA (2021); Smerznak I (2021). 
Moreover, the GameStop case highlighted the existence of four important stock market trends. They relate to the earnings logic of broker-dealers, access to foreign stocks, the design of trading platforms, and access to useful information.

Retail-oriented brokerage firms have eliminated their own commissions and account minimums in the US. ${ }^{438}$ This has made investments easier for various categories of retail investors. In the US, retail brokerage firms can offer zero-commission trades and other benefits to customers, because most of them receive payments for order flow from market makers. With payment for order flow, market makers can provide a rebate for executed orders. ${ }^{439}$ The SEC has permitted payment for order flow since $1994 .{ }^{440}$ There can be even other ways to offer zero-commission trading. For example, eToro earns trading revenue like a classic broker from the spread, and non-trading revenue. Traders can bring in revenue in many ways. ${ }^{441}$

The GameStop phenomenon spread across the globe. Some other companies turned into meme stocks. This was made possible by the fact that retail investors in many countries had access to trading in both domestic and foreign shares through online brokerage firms and new retail trading platforms. It has been common wisdom to assume that high transaction costs associated with direct purchases of overseas securities make this option impractical for many small investors (section 6.4.7). ${ }^{442}$ But high transaction costs do not seem to have been an issue in GameStop.

The user interface of new retail trading platforms can be designed with young retail investors in mind. In his 2021 testimony to Congress, the CEO of Robinhood described the company's approach to design as follows: “At Robin-

\footnotetext{
438 Tenev V (2021), IV.
}

439 Ibid., V. See also The Economist, Pay-per trade, 6 February 2021.

440 Tenev V (2021), V footnote 12 citing Exchange Act Release No. 34-34902, 1994 WL 587790 (Oct. 27, 1994) (Payment for Order Flow) and Exchange Act Release No. 34-43590, 2000 WL 1721163 (Nov. 17, 2000) (Disclosure of Order Execution and Routing Practices).

441 SEC Form 8-K, Current Report Pursuant to Section 13 or Section 15(d) of the Securities Exchange Act of 1934, Fintech Acquisition Corp. V, March 16, 2021, Exhibit 99.1, Investor Presentation, dated March 16, 2021: "-Trading revenue. The trading revenue includes the spread, which is the difference between the Buy and Sell prices of a certain asset, and it is charged when a new trade is opened. Trading revenues derived from equities, crypto and contracts for difference. -Interest income. Margined positions to stay open overnight incur a small fee, releative to the value of the position. This is essentially an interest payment to cover the cost of the margin used overnight. -Currency conversion and other income.” Filippo Ucchino, How does eToro make money? Here's the answer. Investingoal, Last Updated: January 2021.

442 See Simons K (1999); SEC (2016a). 
hood, we pride ourselves on providing access to commission-free investing through an appealing, simple platform. But even though we have made investing easier, we recognize it is not a game. While I am not aware of any agreed upon definition of 'gamification,' I do know that Robinhood Financial designed its app to appeal to a new generation of investors who are more comfortable trading on smartphones than speaking with a broker, and Robinhood has built it to include features that, based on our outreach and research, customers feel familiar with and expect to see in a mobile product. The mobile app provides the intuitive experience customers want, while also providing them with tools and information to learn about investing and keep tabs on their finances. I am confident that the easy-to-use interface enables customers to understand, control, and direct their finances in a responsible way." ${ }^{443}$

The fourth trend seems to be the education of customers complemented by peer-to-peer social media as a source of investment information. The CEO of Robinhood stressed the company's focus on financial literacy. This required avoiding complex industry language and providing useful tools to inform customers. ${ }^{444}$ An investor nevertheless told in his testimony to the Congress that "people didn't really care about boring, repetitive analysis of GameStop and other stocks" and that the Reddit stream made it possible to "analyze events in real-time and keep each other honest". He said that markets are hard to understand regardless of information: "Here's the thing: I've had a bit of experience and even I barely understand these matters. It's alarming how little we know about the inner-workings of the market ..."445

\subsubsection{Social Media Platforms}

Social media played a role in the GameStop case of 2021. We can have a brief look at social media platforms to understand market trends.

Platforms are the most successful business model in digital economy. While platforms have for a long time played a central role in finance as a way to reduce transaction costs, social media is emerging as a new platform for retail finance.

443 Tenev V (2021), VI.

444 Ibid., VII.

445 Gill KP (2021). 
Social media platforms are used by billions of people in the world. Obviously, many people use social media for investment purposes. Platforms facilitate "social finance" as they help beliefs, sentiments, and preferences to spread. ${ }^{446}$ General social media can be used for the dissemination of information for investment purposes (such as Reddit). In addition, there are specialised social media platforms for the sharing of ideas and information about investments (such as Stocktwits, Scutify, or eToro's Open Book). ${ }^{447}$

Because of the large number of users, social media platforms can even benefit issuers. Issuers have followed the crowd and started to use social media platforms for disclosure purposes. In April 2013, the SEC made clear that companies may use social media outlets like Facebook and Twitter to announce key information in compliance with Regulation Fair Disclosure (Regulation FD). ${ }^{448}$ Unlike traditional disclosure channels, social media is a form of pushing information to the public rather than members of the public pulling information. ${ }^{449}$

Traders can analyse the sentiment in social media. Algorithms based on social media play an important role in automated short-term trading of financial instruments. ${ }^{450}$ Social media has made it easier to manipulate markets. ${ }^{451}$ For example, social media has benefited pump-und-dump schemes. Potential market manipulation was an issue in the GameStop case.

While social media creates a virtual trading floor for various kinds of propositions where the prevailing beliefs crystallise in a vague market sentiment, the trades based on the market sentiment will be executed on a trading platform. Where legal, a social media platform could provide a platform for trade execution as well. For example, eToro is a fintech firm that started by offering online trading in high-risk contracts for difference and extended into social trading. ${ }^{452}$ eToro has paid users depending on the size of their following. Other social media platforms that allow users to trade include Collective2 and Voleo.

446 For "social finance”, see Bursztyn L, Ederer F, Ferman B, Yuchtman N (2014); Hirshleifer DA (2015); Han B, Hirshleifer DA, Walden J (2019); The Economist, Free exchange. Regression to the memes, 27 February 2021.

447 Pan W, Altshuler Y, Pentland A (2012).

448 So long as investors have been alerted about which social media will be used to disseminate such information. SEC Release No. 34-69279 (April 2, 2013).

449 Paul T (2015).

450 Cremonesi P, Pagano R, Francalanci C, Mazzoni L, Elahi M, Polipoli A, Maggioni A (2018). 451 See, for example, Article 12(1)(c) and recital 48 of Regulation 596/2014 (Market Abuse Regulation).

452 For social trading, see Pan W, Altshuler Y, Pentland A (2012). 


\subsection{The Structure and Composition of the Board}

\subsubsection{General Remarks}

The theory and practice of corporate governance and the existence of numerous corporate governance codes in the world suggest that certain organisational structures of listed companies are regarded as superior to others. Mainstream corporate governance theory tends to focus on the structure and composition of the board, the duties of the board, the relationship between the board and shareholders, the relationship between the board and the CEO, as well as incentives. Mainstream theory is based on shareholder primacy and the choice of fictive shareholders as the principal.

In contrast, our theory of corporate governance is based on the choice of the firm as the principal (section 2.3.3). The firm relies on board members and reallife shareholders as its agents. This shows the phenomenon of corporate governance in a new light.

In any case, the most basic issues in mainstream theory and practice include the choice between the one-tier board and the two-tier board and the choice of board composition. We can have a brief look at these practices.

\subsubsection{Choice Between the One-Tier or Two-Tier Board}

There are many board models in the world. It would be more useful to focus on the separation of functions (section 2.4.5) than speculate about the contents of the notion of "a board" or, even worse, "the board" (section 2.4.10). ${ }^{453}$ Because of the very rich legal literature on boards, it is sufficient to focus on just some main points.

In the context of corporate governance, there are particular issues that must be addressed one way or another (section 2.3.3). ${ }^{454}$

For example, it is necessary to organise collective decision-making and allocate power, risk, and information between company bodies. ${ }^{455}$ To ensure that the corporate governance model is self-enforcing, ${ }^{456}$ it is necessary to allocate the

453 For a survey on empirical literature, see Adams RB, Hermalin BE, Weisbach MS (2010). 454 For corporate governance issues, see Mäntysaari P (2005) pp 17 and 30 -31; Mäntysaari P (2010a) pp 166-167; Mäntysaari P (2012) p 103.

455 For the allocation of power, risk, and information in corporate governance, see Mäntysaari P (2005) pp 30 -33; Mäntysaari P (2010a) pp 167-168; Mäntysaari P (2012) pp 103-104. 456 See Mäntysaari P (2012) Chapter 8. 
functions of management and monitoring, that is, the functions of the initiation, control, enforcement, and monitoring of decisions, to separate bodies. ${ }^{457}$

These functions have been allocated in various ways in company law and corporate practice depending on the country and the company form. The composition of any corporate body should depend on its function. Mandatory provisions of law and path dependency have played an important role.

Board models. Corporate governance discourse customarily focuses on the governance of large listed companies. It is customary to distinguish between the two-tier board (dual board) and the one-tier board (unitary or single board).

The two-tier board makes it possible to separate different functions at board level. The two-tier board was developed for large companies in Germany and France (section 2.4.5). To improve monitoring under the two-tier board model, the monitoring function can be made independent from the management function by ensuring that the two boards share neither members nor functions, and by ensuring that the monitoring board monitors the managing board rather than management.

The one-tier board traditionally is used in common law countries (section 2.4.5). In Anglo-American corporate practice, it has been customary to vest all powers in the board and give the board discretion to delegate powers and functions to individual directors or sub-board bodies. This has caused an obvious problem: Who monitors the monitors?

The who-monitors-the-monitors problem under the one-tier model has partly been addressed by creating two-tier structures to increase the separation of monitoring and management. It has been customary to allocate a limited monitoring role to external board members and board committees with external ("independent") members as monitors of executive members. ${ }^{458}$ In the absence of statutory two-tier structures for large companies, such practices have been driven by corporate governance codes. The personal "independence" of external board members has been important under the one-tier model. The Sarbanes-Oxley Act was a move towards creating two-tier structures inside a one-tier board. ${ }^{459}$ The financial crisis of 2007-2009 made regulators pay more attention to the separation of monitoring and management in large banks. ${ }^{460}$

457 Fama EF, Jensen MC (1983a); Fama EF, Jensen MC (1983b).

458 Mäntysaari P (2005) section 6.5.3; Hopt KJ (2019b) p 517.

459 Mäntysaari P (2005) section 6.5.3. See even Yamanaka T (2018) on "one-board and threecommittee companies" and "one-board and one-committee companies" as functional equivalents to "two-board companies" in Japan.

460 Basel Committee on Banking Supervision (2015). 
Generally, such new corporate governance practices are necessary under the one-tier model to cure problems that in a German AG largely have been addressed by the strict two-tier model. The two-tier model focuses on the independence of the monitoring function. ${ }^{461}$

Few legal scholars have argued for two-tier boards in the US. ${ }^{462}$ The absence of a clear separation of monitoring and management under the one-tier board model was not perceived as very problematic before the financial crisis of 2007-2009. ${ }^{463}$ In fact, Anglo-American corporate governance studies tend to rank corporate governance in the US and common law countries as superior to the rest of the world.

Attempts to address the who-monitors-the-monitors problem include increasing reliance on shareholders. Under the one-tier board model, shareholders are expected to act as monitors of the board. Since retail investors have neither resources nor incentives to monitor management, institutional investors have in recent regulatory practice been given a monitoring role. ${ }^{464}$ This reflects shareholder primacy with board members and managers as shareholders' "agents" under common law, neoclassical economic theory, or both. Monitoring costs form part of shareholders' "agency costs".

The two-tier board and the one-tier board are not the only board models in the world. In the Nordic countries, it is customary to use a third model that consists of concentrated share ownership, a statutory board with large powers, and a statutory CEO responsible for operative management. ${ }^{465}$ Most large firms have a sub-board management group chaired by the CEO and consting of top execu-

461 See, for example, Mäntysaari P (2005) section 6.5.3. See also Hopt KJ (2019b) pp 533-534: "Bemerkenswert ist ... wie zögerlich die Forderung nach independent directors in Deutschland aufgenommen wurde. Im Aktiengesetz gibt es keine Definition der Unabhängigkeit für Aufsichtsratsmitglieder, und es gibt nur spärliche Regelungen dazu ... Erst der Entwurf für eine Kodexreform für 2018 beinhalte eine Definition und eine ausführliche Liste von Kriterien für die Einschätzung der Unabhängigkeit seiner Mitglieder durch den Aufsichtsrat.”

462 See, for example, Dallas LL (1997). Generally, see Belot F, Ginglinger E, Slovin MB, Sushka ME (2014) p 366.

463 See, for example, Davies P (2001).

464 See, for example, Jiang F, Kim KA (2015) p 192: "Because individual investors in China are, for the most part, uninformed speculators, the Chinese government has increasingly promoted the presence and growth of institutional investors, hoping that they will bring stability, activism, and oversight to the stock markets." See also Directive 2017/828/EU (SRD II); Hopt KJ (2019a) II.3(c): "Whether the hopes placed on better corporate governance by shareholders are justified remains to be seen."

465 Hansen JL (2007); Lekvall P (ed) (2014). 
tives. Since this group is not recognised in company law, its members are in the legal sense employees.

A fourth model is used in China. The Chinese corporate governance system consists of overlapping organisations that belong to the corporate sphere, the state, or the Communist Party of China (CPC). A listed firm in China has a corporate organisation. It must have a board of supervisors and a board of directors. The board of directors makes major decisions and monitors top managers. The primary responsibilities of the board of supervisors are to supervise and evaluate directors and senior managers. ${ }^{466}$ In addition, there is state organisation. Stateowned enterprises (SOEs) are overseen by the powerful State-owned Assets Supervision and Administration Commission (SASAC). ${ }^{467}$ China is run by the CPC and companies are no exception. Each director or supervisor who is a member of the CPC must obey the orders of the Party. The board model can thus be described as a two-tier or three-tier structure, but to understand the nature of corporate governance in China, it is necessary to take into account state and Party organisations as well.

Limited convergence. Because of fundamental differences in company law and board traditions in Europe, Member States' laws on board structure and composition have not been harmonised in the EU (section 2.4.10). Each country applies its own provisions of company law to regulate these issues.

There is some convergence towards the US corporate governance model. Increasing institutional share ownership, the Americanisation of business research and education, the agency theory, and the Americanisation of advisory services and business practices have contributed to the increasing reception of US corporate governance practices in Europe. ${ }^{468}$

Convergence is hampered by path dependency. Path dependency is increased by the nature of company law as a matrix (section 2.3.3), the key design principle (section 2.4.16), and the goal of the coherence of the legal framework. There is perhaps more convergence in academic discourse and business culture than in the letter of the law.

Convergence is not one-way traffic but seems to work in both directions (section 2.4.13). For example, corporate scandals such as Enron led to the SarbanesOxley Act (SOX) in the US. SOX was a move from state company law to federal company law and better separation of monitoring and management in public

466 Jiang F, Kim KA (2015) pp 193-194. For corporate governance in China, see Milhaupt CJ (2017).

467 Jiang F, Kim KA (2015) p 195.

468 André T Jr (1998); Fiss PC, Zajac EJ (2004); Kieser A (2004); von Hein (2008) p 376. 
limited-liability companies. The financial crisis of 2007-2009 made regulators pay more attention to the separation of monitoring and management in large banks. ${ }^{469}$ In the absence of a two-tier model, two-tier structures are created inside the one-tier board with external members as monitors of executive members. ${ }^{470}$ Moreover, problems caused by shareholder primacy have increased interest in continental European corporate governance practices.

Choice. Generally, different kinds of firms may need different kinds of organisational structures, company forms, and boards (for venture capital board practices, see section 5.3). ${ }^{471}$ Where firms may choose between the two-tier board and the one-tier board according to their needs (such as a management-friendliness or financial monitoring), ${ }^{472}$ one could expect the board model not to affect firm value very much. You simply need different tools for different tasks: any carpenter would tell you that a saw is not superior to a hammer as such.

For example, France has since 1966 permitted public companies to adopt either a unitary or two-tier board and to reverse the decision over the company's life cycle. A study found little evidence for any widespread effect of board structure on firm value in French public companies. ${ }^{473}$

The same study found evidence of how the characteristics of the firm influence the structure of the board in closely-held firms. When there is a founder or, in family firms, a first-generation CEO, a closely-held firm is significantly more likely to adopt a unitary board structure. ${ }^{474}$ Professional management or management by a subsequent generation at a closely-held firm increases the likelihood of a two-tier board structure. ${ }^{475}$ Among closely-held firms with a unitary board structure, firms with professional managers tend to split the leadership positions (président and directeur general). Firms controlled by the founder or

469 Basel Committee on Banking Supervision (2015).

470 Mäntysaari P (2005) section 6.5.3; Hopt KJ (2019b) p 517.

471 Belot F, Ginglinger E, Slovin MB, Sushka ME (2014) p 376: “Overall, the evidence supports the view that firm characteristics have an important influence on board structure and the intensity of monitoring."

472 Adams RB, Ferreira D (2007) argued that management-friendly boards can be optimal. Belot F, Ginglinger E, Slovin MB, Sushka ME (2014) p 365: "Our results for two-tier boards indicate the usefulness of the Adams and Ferreira (2007) framework which suggests that a friendly board may often be the appropriate form of governance, but for certain firms a two-tier board structure that fosters greater monitoring could be more appropriate." See also Mäntysaari $\mathrm{P}$ (2010a) pp 174-175; Mäntysaari P (2012) pp 108-109, 137 and 145.

473 Belot F, Ginglinger E, Slovin MB, Sushka ME (2014) p 365. See also Hopt KJ (2019b) p 522. 474 Belot F, Ginglinger E, Slovin MB, Sushka ME (2014) p 376.

475 Ibid., p 376. 
a member of the first generation tend to unify the positions (Président Directeur Général, PDG). ${ }^{476}$

In the EU, firms have some discretion when choosing the board model. First, the national company laws of each Member State can provide for alternative company forms. There is thus built-in flexibility in Member States' national company laws. Second, there is a European company form. The SE is a European public limited-liability company form with either a one-tier board or a two-tier board. ${ }^{477}$ An SE may be founded in any Member State and is governed by the law of the Member State in which it has its registered office. There is perhaps no great demand for the additional flexibility provided by the SE in the light of the fact that few large firms choose the SE as their main company form. ${ }^{478}$ Third, firms established in the EU may use the national company forms of any Member State under freedom of establishment. ${ }^{479}$ In EU company law, the regulation of boards has not been harmonised due to fundamental differences between Member States' laws.

In US corporate practice, the board model is fixed by the founders. The reaction to the irrevocable nature of the corporate charter (Dartmouth College) is to vest all powers in the board.

\subsubsection{Board Composition}

There are many studies on the effect of board composition on "firm value" in listed companies. Such studies must start with the notion of "firm value" and the choice of dependent variables. According to traditional finance literature, firm value can be measured as stock market performance, accounting performance, or a mix of both performance measures. ${ }^{480}$

According to mainstream theory, important elements of good corporate governance include board independence, management share ownership, and blockholding. ${ }^{481}$ First, good corporate governance is assumed to require independent

476 Ibid., p 378.

477 Council Regulation (EC) No 2157/2001 of 8 October 2001 on the Statute for a European company (SE).

478 There is no central registry of SEs in Europe. The European Trade Union Institute (ETUI) has its own database of registered SEs. See also Belot F, Ginglinger E, Slovin MB, Sushka ME (2014) p 367.

479 See, for example, C-212/97 Centros [1999] ECR I-1459; Mäntysaari P (2010a) section 4.4.4. 480 See Jentsch V (2019) section 3.1.1 pp 214-215.

481 Jentsch V (2019) p 203. 
board members and the separation of the roles of the CEO and the chairman of the board. Second, good corporate governance is assumed to require management share ownership in order to align managers' interests with the interests of shareholders and to reduce agency costs. ${ }^{482}$ Third, large shareholders are assumed to be efficient monitors.

However, board composition probably should depend on the function of the board, the board model, the characteristics of the firm, the characteristics of the market (that is, the firm's business), and regulatory compliance (that is, the preferences of the state). If this is true, it is likely to reduce the usefulness of studies that find a connection between board composition and firm value. ${ }^{483}$ This can be illustrated with a recent article by Jentsch. ${ }^{484}$

In a 2019 article, Jentsch studied the effect of board composition on firm value in large listed companies in Switzerland. Jentsch pointed out that earlier empirical evidence on the effectiveness of the traditional elements of what is perceived as good corporate governance is mixed at best. ${ }^{485}$

According to the 2019 article, firm value is decreased when the share of independent board members is increased or when the significant shareholders are institutional investors. Firm value is increased when board members include current or former executives, when the chairman has executive functions, or when the CEO sits on the board. Jentsch made various proposals based on these results. They included, for example: the appointment of a majority of independent directors rather than a supermajority; permitting the representatives of significant shareholders to act as "enhanced-independence" directors; permitting a combined CEO and chairman role; vesting stronger minority rights in shareholders; and making the controlling shareholder subject to a duty of loyalty in relation to the company and/or public shareholders.

Using the 2019 article as a basis of discussion, the results could be interpreted in other ways. It would be important to distinguish between the independence of individual board members and the independence of the monitoring function, and between shareholders that are good or bad providers of ancillary services.

482 Jensen MC, Meckling WH (1976).

483 See Bhagat S, Black BS (1999) on the weak empirical support for boards with a majority of independent members and Bebchuk LA, Hamdani A (2017) p 1274: "[T]he existing arrangements for electing directors undermine the effectiveness of independent director oversight ... [I]ndependent directors currently relied upon to contain controllers' conflicts cannot be expected to be effective guardians of public investors' interests."

484 Jentsch V (2019).

485 For a survey, see Adams RB, Hermalin BE, Weisbach MS (2010). 
First, decisions taken by so-called independent directors cannot generally be expected to be better than decisions taken by executive or non-independent directors. Decisions tend to be of better quality when they are based on better information. In a listed company, executive or non-independent directors and former CEOs tend to know the firm very well. Independent directors tend to be less knowledgeable about the firm. ${ }^{486}$ To signal their own competence and neutralise the problem with asymmetric information, independent directors may in their monitoring role need to rely more on standard practices such as financial incentive schemes. This is likely to increase CEO pay. ${ }^{487}$ The quality of independent but less knowledgeable directors' decision-making would hardly be improved by creating a new class of even more independent ("enhanced-independence") board members even more accountable to public shareholders than their standard-independent peers. ${ }^{488}$ A better alternative could be to ensure, on one hand, the participation of professional and specialised corporate insiders in corporate functions and, on the other, the independence of the monitoring function through structural measures such as the use of a two-tier board, the separation of work, specialisation, and mixed monitoring. The monitoring function needs knowledgeable and competent people regardless of whether they are "independent" or not.

Second, it is probably better to have a chairman who knows the firm well than a chairman who does not. Most chairmen of the top 20 global companies by market capitalisation are knowledgeable because they are not independent in their personal capacity. ${ }^{489}$ Founders, controlling shareholders, long-time board members or former CEOs know the company very well.

Third, institutional investors may not be good monitors in the long term. Institutional investors typically invest other people's money and diversify other people's investments. Their own risk exposure is very limited and their own interests are not aligned with the long-term interests of the firm. ${ }^{490}$ When institu-

486 See even Bhagat S, Black BS (1999); Brickley JA, Coles JL, Jarrell G (1997).

487 See Adams RB, Hermalin BE, Weisbach MS (2010) p 70 on Hermalin's model.

488 Enhanced-independence directors were proposed by Bebchuk LA, Hamdani A (2017).

489 Tom Braithwaite, Who cares about independent chairs? Financial Times, 5 February 2021. 490 See, for example, Shleifer A, Vishny R (1986) pp 463-463: "We expect that financial managers and especially individual and corporate investors would monitor the management and sometimes initiate a takeover or invite third parties to do so. Indeed, our preliminary evidence suggests that large shareholders play an important role in takeovers. Even when they cannot monitor the management themselves, large shareholders can facilitate third-party takeovers by splitting the large gains on their own shares with the bidder.” 
tional investors have made investments in a fund managed by a fund management company, the monitoring function is delegated to the fund management company. ${ }^{491}$ Voting and ownership are separated in fund portfolio companies ("empty voting").492 Fund management companies and institutional investors can reduce their own operational costs by outsourcing monitoring to proxy-advisory firms. The use of proxy-advisory firms reduces proximity to portfolio companies. These practices have had serious effects on corporate governance. One of the things learnt after the financial crisis of 2007-2009 was that institutional investors were poor monitors of banks. For these reasons, empowering institutional investors or representatives of fund management companies at board level would hardly be the right way to foster the long-term interests of the firm. Neither would it be meaningful to increase institutional investors' company law rights as minority shareholders.

Fourth, where the company has an individual as a controlling shareholder, the company tends to be controlled by a knowledgeable person regardless of the controlling shareholder's formal position in the company. For example, Tesla is controlled by Elon Musk regardless of whether he is or is not the chairman.

Fifth, the existence of good controlling shareholders can improve the overall services of shareholders and reduce their cost. The future of the firm can depend on the quality of controlling shareholders. This is the case both in growth firms and established firms. ${ }^{493}$ Controlling shareholders generally have access to better information about the firm. Where the private benefits of controlling shareholders are aligned with the interests of the firm, private benefits can reduce the cost of their services to the firm. ${ }^{494}$ For example, the existence of a large long-term block-holder will protect an established firm against hostile bids and reduce the need to pay for other structural takeover defences (such as the need to distribute funds to shareholders in order to increase leverage and share price). ${ }^{495}$ Moreover, there is a positive correlation between ownership concentration and R\&D expenditures. ${ }^{496}$ The extreme case is the business model of tech start-

491 Jensen MC (1989): "Institutional investors delegate the job of being active monitors to agents best qualified to play the role."

492 Hu HTC, Black BS (2006a); Hu HTC, Black BS (2006b); Hu HTC, Black BS (2007).

493 See Bebchuk LA, Hamdani A (2017) p 1279 on publicly-traded companies. See also Thomsen S (1996); Schroeder D, Thomsen S (2021) on foundation ownership and economic performance.

494 Mäntysaari P (2010a) section 9.2.6 p 218 and section 9.4.2 pp 274-275.

495 Mäntysaari P (2010a) section 9.4.2; Mäntysaari P (2010c) Chapter 18.

496 See Mäntysaari P (2012) section 9.4.4 p 136. 
ups. Such firms tend to have one or more controlling shareholders that are founders or venture capital investors. ${ }^{497}$ In such firms, good controlling shareholders are expected to focus on the burn rate and fast growth. This makes traditional accounting "firm value" irrelevant but is intended to increase the valuation of the firm in each funding round.

\subsubsection{Guidelines on Corporate Governance Principles for Banks}

The most detailed global framework of design principles for boards applies to banks. In 2015, Basel Committee on Banking Supervision issued authoritative guidelines on corporate governance principles for banks. ${ }^{498}$ They have had an impact on the principles and guidelines of other international and national supervisory institutions. In the EU, they have influenced the Capital Requirements Directive (CRD IV) and the Solvency II Directive. ${ }^{499}$ Most of the principles focus on the board.

The detailed design principles reflect at least four higher-level design principles. The first is ensuring "banks' safety and soundness" or "the safe and sound functioning of a bank". ${ }^{500}$ The second is ensuring the sustainability of banks especially in relation to their stakeholders. ${ }^{501}$ Third, among banks' stakeholders, shareholders' interest is secondary to depositors' interest. ${ }^{502}$ Fourth, it is assumed that there must be a board as the body that supervises management. The board is defined neutrally, because the guidelines are designed to be applied in many jurisdictions worldwide. ${ }^{503}$

The rejection of shareholder primacy and the recognition of depositors' interests should not really change the interest of the bank-firm for its own longterm survival. Neither should they change the function of shareholders as agents of the bank-firm and the need for good ancillary services. But the guidelines should change the non-recognition of the interests of the bank-firm and practices

497 When Bebchuk LA, Hamdani A (2017) pp 1279-1280 described abuses by controlling shareholders, they seem to have had large traditional listed corporations, the mainstream principalagent theory, and the financial business model in mind. Little of this describes the business model of modern growth firms.

498 Basel Committee on Banking Supervision (2015).

499 See Hopt KJ (2021) pp 19-20.

500 Basel Committee on Banking Supervision (2015) paragraphs 1 and 5.

501 Ibid., paragraph 2.

502 Ibid., paragraph 2.

503 Ibid., Glossary, definition of "board of directors, board". 
designed to align the interests of board members and managers with those of shareholders under the now rejected shareholder primacy. What the guidelines should not mean is replacing shareholder primacy with equally narrow-minded "creditor governance". The long-term survival of the bank-firm in competitive markets requires much more than making sure that depositors do not lose their money. ${ }^{504}$ Banks that just focus on depositors not losing their money could soon be replaced by central banks that are planning to launch their own digital currencies. Shortly put, the guidelines do not make it necessary to have creditors sitting on the board..$^{505}$

Since the guidelines are applied in many jurisdictions, the guidelines are not based on a strict separation of the supervision and management functions at individual level. There may be both executive and non-executive board members. ${ }^{506}$ In the absence of the strict separation of supervision and management functions, the guidelines address the individual and collective quality of board members (Principle 2), how the board structures itself (Principle 3), and senior management (Principle 4).

According to the guidelines, board members owe a "duty of care" and a "duty of loyalty" to the bank under the applicable law. ${ }^{507}$ Both have been defined in the guidelines. ${ }^{508}$ The duty of care means the duty of board members to "decide and act on an informed and prudent basis with respect to the bank". According to the guidelines, it is often "interpreted as requiring board members to approach the affairs of the company the same way that a 'prudent person' would approach his or her own affairs". The duty of loyalty means the duty of board members to "act in good faith in the interest of the company". According to the guidelines, this duty "should prevent individual board members from acting in their own interest, or the interest of another individual or group, at the expense of the company and shareholders".

The guidelines do not discuss whether such general duties are owed by senior management. This reflects that fact that sub-board senior management ei-

504 For a slightly different view, see Hopt KJ (2021) p 22: "This position is a clear rejection of the shareholder primacy view ... Creditor governance is not just a question of the purpose of bank corporations, instead having consequences in many other areas regarding the corporate governance of banks. In particular this view reduces also the relative importance of controlling shareholders, institutional investors and shareholder control in general, as is presently the center of attention in the corporate governance of (non-bank) corporations.”

505 For the opposite view, see Hopt KJ (2021) p 24.

506 Basel Committee on Banking Supervision (2015) Glossary, definition of “executive director” and "independent director", paragraphs 18 and 47.

507 Ibid., paragraph 25.

508 Ibid., Glossary. 
ther does or does not fall within the scope of company law depending, in particular, on whether the applicable law reflects the one-tier or two-tier board model. Members of senior management nevertheless have duties according to the guidelines. The individuals that belong to senior management are responsible for "the sound and prudent day-to-day management of the bank". They are accountable to the board. ${ }^{509}$ According to the guidelines, senior management should be directed by board policies and personal incentives when managing the bank's activities. ${ }^{510}$

While the guidelines stress the importance of corporate and risk culture, ${ }^{511}$ corporate culture is weakened by the fundamentally different treatment of the ethical duties of the board and senior management. While board members owe a "duty of care" and a "duty of loyalty" to the bank, the individuals that form senior management are not expected to be motivated by such duties owed to the bank. Under the guidelines, their expected standards of behaviour should be designed to reflect how the cultural values of the bank are put into practice by the board through board policies and incentive systems. There could be overreliance on decisions of the board as regards creating an internal culture and the "tone at the top" 512 if members of senior management are expected to be guided by their own personal benefits. ${ }^{513}$

\subsubsection{Conclusions}

There are many alternative board models. While the perceived quality of a board model can depend on the chosen theory, the quality of a board model for any particular firm depends on the characteristics of the firm. Firms are different. If firms may choose the structure and composition of the board according to their own needs, rational firms may end up with different board models. If this happens, the effect of any particular board model on overall economic performance is neutralised. Regulators should therefore ensure that companies may use different board models.

509 Ibid., paragraph 87.

510 Ibid., Principle 4: "Under the direction and oversight of the board, senior management should carry out and manage the bank's activities in a manner consistent with the business strategy, risk appetite, remuneration and other policies approved by the board."

511 See, for example, ibid., paragraphs 3, 11, 14, 26, 29-30, 40, 46, 76, 91, 93, 162 and 164. 512 For the "tone at the top, see ibid., paragraphs 14, 30, 91 and 162.

513 See ibid., paragraphs 143 and 148. 


\subsection{General Conclusions Based on Current Market Practices}

We can draw several general conclusion from current market practices. Low IPO levels and greater financial inequalities are the result of many powerful trends and seem to have become permanent. The existing regulatory framework can be improved, but it may take radical innovation to increase the number of companies with publicly-traded shares and retail investors' direct share ownership.

Company law, stock exchange law, securities law. It is necessary to improve company law, stock exchange law and securities law.

Angel funding and venture capital practices indicate that market regulation should make it easy for firms to take steps from early-stage funding to later-stage funding. A secondary market for shares can support the primary market.

If there is a new exchange or segment for small companies, it should be an exchange or segment for SMEs rather than start-ups. It is necessary to address the inherent illiquidity of SME shares by admission requirements, the principles of the matching of bids, and market making. Moreover, mentoring may be necessary in order to prevent a market for lemons. The LTSE model indicates that there may be room for innovative ways to reduce costs.

Operating firms prefer discretion to choose the terms of their own public listing. The raising of funding can be separated from the public listing. IPOs may not be necessary for funding purposes. A privately-held company can avoid or postpone an IPO by raising funding privately. An IPO can be replaced by a direct listing or a de-SPAC business combination. It may not be necessary for a publiclytraded company to raise cash from its shareholders. A publicly-traded company can use its shares as a means of payment in mergers and acquisitions, and it can avoid rights issues when it raises cash through PIPEs. A public listing can primarily be seen as a way to create secondary trading for shares and a way to enable business combinations. To increase the number of companies with publiclytraded shares, stock exchanges for small growth firms should primarily be designed as secondary markets. It is easier to organise stock exchanges as secondary markets than primary markets.

Traditional issuer disclosures do not work if few investors can follow and understand them. Regulators should beware of overreliance on traditional disclosures. Issuers' mandatory disclosure obligations should be reduced if they reduce IPO levels and the number of companies with publicly-traded shares without improving the welfare of retail investors as a class.

Fund and SPAC practices indicate that it is customary to separate investments by market investors and the raising of funding by operating companies through the use of intermediaries that pool investments. When making such investments, retail investors require little voice. Instead, they rely on regulatory 
compliance and the expertise of professionals. Retail investors do not need increased minority rights for monitoring purposes. Increased minority rights might reduce their investment opportunities, because retail investors will get no chance to invest in stocks in the first place unless it is in the interests of issuer-firms and/or their controlling shareholders.

The practices of angel investors and SPAC practices could to some extent be used as a model for regulating the rights of retail investors. Angel investors protect their rights in later funding rounds and exits. While SPAC shareholders are not guaranteed any particular rights in the operating company in advance, they have the rights of holders of common stock in the SPAC, may vote on the business combination with the operating company, and may exit the SPAC.

To increase the viability of the business project and to reduce the risk exposure of new investors, it could be useful to ensure that founders and key shareholders are committed to the project for a certain number of years. This requires lock-ins. However, lock-ins may be less necessary in a direct listing or SPAC business combination.

The board model can depend on the share ownership and control structure. On one hand, monitoring and management in a company that has a dispersed share ownership structure could be improved by the use of two-tier boards. On the other, there are companies in which share ownership, management, and monitoring are not separated. There is no clear separation of share ownership and management in entrepreneur-managed operating companies or companies with a controlling shareholder. To protect firms with a dispersed share ownership structure and to bring more entrepreneur-managed companies and companies controlled by a controlling shareholders to public markets, the firm should be able to choose between alternative board models.

Access to trading in foreign stocks seems to have been improved by new online trading platforms and broker-dealer competition. However, access to trading in foreign stocks does not seem to have had any major impact on the overall number of companies with publicly-traded shares.

A better legal environment for start-ups. Company law, stock exchange law, and securities law may not be enough to increase the number of companies with publicly-traded shares. To address the concentration of economy, the business of start-ups and young growth firms should be embedded in a better legal environment. ${ }^{514}$ The rules of the game should be made to work for young firms.

514 Rose P, Solomon SD (2016) p 127: "Put another way, the primary issue is not how to get companies to market, which may merely create a false supply, but how to create a regulatory and market environment that fosters growth in small companies.” The role of the broader regulatory framework can be seen in the failure of European company forms. Ghetti R (2018) p 835. 
For example, bankruptcy laws, non-compete obligations for employees, and competition laws can hamper new entrepreneurial ventures. We can have a brief look at these examples.

First, from the perspective of the potential entrepreneur, stringent bankruptcy laws are discouraging because they add to the perceived cost of starting a business. Moreover, the personal liability of board members can lead to boards that are either too risk averse (when board members understand the risk they are taking) or clueless (when board members are uncritical of risk taking). ${ }^{515}$

US bankruptcy law favours entrepreneurship. In the US, bankruptcies are governed by federal law under the Bankruptcy Code. The benefits of the Bankruptcy Code are not limited to debt restructuring under Chapter $11 .{ }^{516}$ Chapter 7 of the Bankruptcy Code gives honest individual debtors a fresh start by discharging them of debt.

European insolvency systems vary widely across the Member States. The most important benefit of a common bankruptcy system for the Member States of the EU would perhaps not be connected to cross-border transactions. It would be far more important to get rid of national systems that favour banks and hamper entrepreneurial risk-taking by preventing the discharge of debt. The Directive on restructuring and insolvency ${ }^{517}$ adopted in 2019 is a step in the right direction. The purpose of the Directive is to give entrepreneurs a second chance.

Second, it is important for local tech start-ups and growth firms to be able to recruit talent globally. For example, Silicon Valley has a high share of foreignborn population. In the core age group in computer and mathematical occupations, $70.5 \%$ of Silicon Valley employees were foreign born in $2017 .^{518}$ France has created a special tech visa to make it easier for the tech sector to import talent. ${ }^{519}$

515 Finch V (2002) p 542.

516 For Chapter 11, see, for example, Gilson SC (2012).

517 Directive (EU) 2019/1023 on preventive restructuring frameworks, on discharge of debt and disqualifications, and on procedures concerning restructuring, insolvency and discharge of debt.

518 Age group 25-44. San Mateo and Santa Clara Counties. Source: Joint Venture Silicon Valley \& Institute for Regional Studies, 2019 Silicon Valley Index.

519 Harriet Agnew, Paris overtakes Berlin for tech start-ups after boost from Macron, Financial Times, 25 October 2019: “Two-and-a-half years on, the country's tech ecosystem appears to be benefiting from measures including the scrapping of a wealth tax on all assets other than property, a flat tax on dividends and an easier process to wind down companies. The most important change, according to the French tech industry, was the creation of a special tech visa, making it easier for the sector to import talent." 
Third, non-compete clauses in employment contracts can hamper new ventures. California is a good example of what can happen when the use of noncompete clauses is restricted.

In California, employees are relatively free to find a new job or found a business. The use of non-compete obligations to bind employees to their employer has been restricted since the California Civil Code of $1872^{520}$ and is still restricted under California Business and Professions Code. ${ }^{521}$

Californian law protects the property rights of the employee: "Every individual possesses as a form of property, the right to pursue any calling, business or profession he may choose. A former employee has the right to engage in a competitive business for himself and to enter into competition with his former employer, even for the business of those who had formerly been the customers of his former employer, provided such competition is fairly and legally conducted."522

In other words, the interests of the employee to find a better job or found a business are regarded as more important than the interests of the current employer. ${ }^{523}$ These rights have been very important for both start-ups and employees. Start-ups have been able to recruit the best employees and employees have been able to earn high wages. ${ }^{524}$

Fourth, the concentration of business can create a kill zone around tech giants and other large firms. Competition law and industrial policy should be adapted to digital economy to ensure that there is room for young firms.

High-level policy objectives. More needs to be done if the goal is to increase the number of companies with publicly-traded shares and retail investors' direct share investments. One can highlight four objectives for future policy.

First, countries and regulators should focus on what increases the wealth of ordinary people so that they can have savings and a surplus to invest. It is not

520 The original wording of $\S 1673$ of the California Civil Code of 1872: "Every contract by which any one is restrained from exercising a lawful profession, trade, or business of any kind, otherwise than is provided by the next two sections, is to that extent void."

521 Section 16600 of California Business and Professions Code, the current section 16600: "Except as provided in this chapter, every contract by which any one is restrained from engaging in a lawful profession, trade or business of any kind is to that extent void."

522 Cont'l Car-Na-Var Corp. v. Moseley, 24 Cal. 2d 104, 110 (Cal. 1944).

523 Diodes, Inc. v. Franzen, 260 Cal. App. 2d 244, 255 (Cal. Ct. App. 1968): "The interests of the employee in his own mobility and betterment are deemed paramount to the competitive business interests of the employers, where neither the employee nor his new employer has committed any illegal act accompanying the employment change."

524 See Lee CM, Miller WF, Hancock MG, Rowen HS (eds) (2000). 
enough to focus on the narrow sphere of company law, stock exchanges law, and securities law.

Second, regulators should more generally focus on legislative reforms that can help young growth firms. ${ }^{525}$ A greater pool of firms can result in more firms that prefer to have publicly-traded shares and more firms to invest in.

Third, regulators should focus on making public markets attractive to firms, founders, and entrepreneurs. Markets designed with the interests of institutional investors and financial intermediaries in mind might not work for non-financial firms. Regulators should learn from recent market practices.

Fourth, there should be an alternative to venture capital. The abundance of early-stage funding from institutional investors has reduced traditional IPO levels. ${ }^{526}$ A firm backed by venture capital may not need to raise other funding, and venture capital investments often lead to a trade sale. Regulators should focus on firms that either do not want or cannot raise venture capital.

In the following Chapter, we will try to develop new design principles on the basis of recent and earlier regulatory and corporate practices. Radical innovation is necessary to break the trend.

\section{References}

Adams RB, Ferreira D (2007) A theory of friendly boards. Journal of Finance 62(1):217-250

Adams RB, Hermalin BE, Weisbach MS (2010) The role of boards of directors in corporate governance: a conceptual framework and survey. Journal of Economic Literature 48(1):58-107

André T Jr (1998) Cultural Hegemony: The Exportation of Anglo-Saxon Corporate Governance Ideology to Germany. Tulane Law Review 73:69-171

Appelbaum E, Batt R (2014) Private Equity at Work: When Wall Street Manages Main Street. Russel Sage Foundation, New York

Armour J, Bengtzen M, Enriques L (2018) Chapter 8. Globalization. In: Fox MB, Glosten LR, Greene EF, Patel MS (eds) Securities Market Issues for the 21st Century. Prepared in connection with The New Special Study a project of Columbia Law School \& Columbia Business School's Program in the Law and Economics of Capital Markets. Independently published, pp 385-477

Basel Committee on Banking Supervision (2015) Guidelines. Corporate Governance Principles for Banks. Bank for International Settlements, Basel

Baskin JB, Miranti PJ Jr (1997) A History of Corporate Finance. Cambridge University Press, Cambridge and New York

525 See, for example, Elert N, Henrekson M, Sanders M (2019).

526 See, for example, The Economist, Buttonwood. VC after Softbank, 2 November 2019. 
Baums T, Hutter S (2003) Die Information des Kapitalmarkts beim Börsengang (IPO). In: Habersack M, Hommelhoff P, Hüffer U, Schmidt K (2003) Festschrift für Peter Ulmer zum 70. Geburtstag am 2. Januar 2003. De Gruyter Recht, Berlin, pp 779-799

Bautz JF (2021) What Is the SEC Going To Do About GameStop? NYSBA.org, News Center, 4 February 2021

Bebchuk LA, Hamdani A (2017) Independent directors and controlling shareholders. University of Pennsylvania Law Review 165(6):1271-1315

Belot F, Ginglinger E, Slovin MB, Sushka ME (2014) Freedom of Choice between Unitary and Two-Tier Boards: An Empirical Analysis. Journal of Financial Economics 112(3):364-385

Bergman MS, Borisoff RS, Howson NC (1994) First direct listing for Chinese company in New York. International Financial Law Review 13:41-44

Berlin M (1998) That Thing Venture Capitalists Do. Business Review, Federal Reserve Bank of Philadelphia, issue January, pp 15-26

Bhagat S, Black BS (1999) The Uncertain Relationship between Board Composition and Firm Performance. Business Lawyer 54(3):921-963

Boreiko D, Ferrarini G, Giudici P (2019) Blockchain Startups and Prospectus Regulation. European Business Organization Law Review 20:665-694

Bratton WW (2002) Venture Capital on the Downside: Preferred Stock and Corporate Control. Michigal Law Review 100:891-945

Brickley JA, Coles JL, Jarrell G (1997) Leadership structure: Separating the CEO and Chairman of the Board. Journal of Corporate Finance 3:189-220

Broughman BJ, Fried JM (2013) Carrots and Sticks: How VCs Induce Entrepreneurial Teams to Sell Startups. Cornell Law Review 98:1319-1357

Brunnermeier MK, Pedersen LH (2005) Predatory Trading. The Journal of Finance 60:1825 $-1863$

Burghof HP, Hunger A (2003) Access to Stock Markets for Small and Medium-Sized Growth Firms: The Temporary Success and Ultimate Failure of Germany's Neuer Markt. Working paper, October 2003

Bursztyn L, Ederer F, Ferman B, Yuchtman N (2014) Understanding Mechanisms Underlying Peer Effects: Evidence from a Field Experiment on Financial Decisions. Econometrica 82(4):1273-1301

Campbell RB Jr (1978) Santa Fe Industries, Inc. v. Green: An Analysis Two Years Later. Maine Law Review 30:187-206

Catalini C, Fazio C, Murray F (2016) Can Equity Crowdfunding Democratize Access to Capital and Investment Opportunities? MIT Innovation Initiative. Lab for Innovation Science and Policy Report. Massachusetts Institute of Technology

Clayton J (2019) SEC Chairman Jay Clayton, Remarks to the Economic Club of New York, 9 September 2019

Coates J (2021) SPACs, IPOs and Liability Risk under the Securities Laws. U.S. Securities and Exchange Commission, April 8, 2021

Coates J, Munter P (2021) Staff Statement on Accounting and Reporting Considerations for Warrants Issued by Special Purpose Acquisition Companies ("SPACs"). Division of Corporation Finance and the Office of the Chief Accountant, U.S. Securities and Exchange Commission, April 12, 2021

Coffee JC Jr (2018) The Spotify Listing: Can an “Underwriter-less” IPO Attract Other Unicorns?, The CLS Blue Sky Blog, 16 January 2018 
Colombo MG, Cumming DJ, Vismara S (2016) Governmental Venture Capital for Innovative Young Firms. The Journal of Technology Transfer 41(1):10-24

Coyle JF, Green JM (2014) Contractual Innovation in Venture Capital. Hastings Law Journal 66:133-183

Coyle JF, Green JM (2017) Startup Lawyering 2.0. North Carolina Law Review 95(5):1403-1432

Cremonesi P, Pagano R, Francalanci C, Mazzoni L, Elahi M, Polipoli A, Maggioni A (2018) Social Network based Short-Term Stock Trading System. Cornell University

Da Rin M, Hellmann T, Puri M (2013) A Survey of Venture Capital Research. In: Constantinides GM, Harris M, Stulz RM (eds) Handbook of the Economics of Finance. Handbooks in economics, Volume 2 A Corporate Finance. Elsevier/North-Holland, Amsterdam, Boston, pp 573-648

Dallas LL (1997) Proposals for Reform of Corporate Boards of Directors: The Dual Board and Board Ombudsperson. Washington and Lee Law Review 54(1):92-147

Damrau J (2003) Selbstregulierung im Kapitalmarktrecht: Eine rechtsökonomische Analyse der Normsetzung der deutschen Börsen und ihrer Träger. Diss. Göttingen 2003. Tenea, Berlin

Davies P (2001) Struktur der Unternehmensführung in Großbritannien und Deutschland: Konvergenz oder fortbestehende Divergenz? Zeitschrift für Unternehmens- und Gesellschaftsrecht 30(2):268-293

de Fontenay E (2017) The Deregulation of Private Capital and the Decline of the Public Company. Hastings Law Journal 68:445-502

Demiroglu C, Ryngaert M (2010) The First Analyst Coverage of Neglected Stocks. Financial Management 39(2):555-582

Denenberg AF, Fausten M, Truesdell RD (2019) NYSE Direct Listing Proposal. Harvard Law School Forum on Corporate Governance, December 13, 2019

Denis DJ (2004) Entrepreneurial finance: an overview of the issues and evidence. Journal of Corporate Finance 10(2):301-326

Deutsche Börse AG (2017) Scale: a comprehensive ecosystem for growth. Interview with Renata Bandov on Deutsche Börse's new SME segment, 5 May 2017

Deutsche Börse AG (ed) (2001) Neuer-Markt-Report. Zugang zu Europäischen Kapitalmarkt Schlüssel für Wachstum. Frankfurt am Main

Díez FJ, Leigh D, Tambunlertchai S (2018) Global Market Power and its Macroeconomic Implications. IMF Working Paper WP/18/137. Western Hemisphere Department and Research Department. International Monetary Fund, June 2018

Dimitrova L (2017) Perverse Incentives of Special Purpose Acquisition Companies, the "Poor Man's Private Equity Funds". Journal of Accounting and Economics 63(1):99-120

Doidge C, Kahle KM, Karolyi GA (2018) Eclipse of the Public Corporation or Eclipse of the Public Markets? Journal of Applied Corporate Finance 30(1):8-16

Doidge C, Karolyi GA, Stulz RM (2017) The U.S. Listing Gap. Journal of Financial Economics 123(3):464-87

Elert N, Henrekson M, Sanders M (2019) The Entrepreneurial Society: A Reform Strategy for the European Union. International Studies in Entrepreneurship Volume 98. Springer Open, Berlin

ESMA (2019) Questions and Answers: On MiFID II and MiFIR investor protection and intermediaries topics. ESMA35-43-349, 18 February 2019 
European Commission (2009) Final Report of Expert Group - Overview of Family-Business Relevant Issues: Research, Networks, Policy Measures and Existing Studies. Enterprise and Industry Directorate-General, November 2009.

Ewens M, Farre-Mensa J (2020) The Deregulation of the Private Equity Markets and the Decline in IPOs. The Review of Financial Studies, hhaa053

Ewens M, Gorbenko AS, Korteweg A (2020) Venture Capital Contracts. Working paper, May 2020

Fama EF, Jensen MC (1983a) Separation of Ownership and Control. The Journal of Law \& Economics 26(2):301-325

Fama EF, Jensen MC (1983b) Agency Problems and Residual Claims. The Journal of Law \& Economics 26(2):327-349

Ferrell A, Morley JD (2018) Chapter 7. The Regulation of Intermediaries. In: Fox MB, Glosten LR, Greene EF, Patel MS (eds) Securities Market Issues for the 21st Century. Prepared in connection with The New Special Study a project of Columbia Law School \& Columbia Business School's Program in the Law and Economics of Capital Markets. Independently published, pp 313-384

FESE (2019) FESE Blueprint: Capital Markets Union by 2024. Federation of European Stock Exchanges, Brussels

Finch V (2002) Corporate Insolvency Law: Perspectives and Principles. Cambridge University Press, Cambridge

Fiss PC, Zajac EJ (2004) The Diffusion of Ideas over Contested Terrain: the (Non)adoption of the Shareholder Value Orientation among German Firms. Administrative Science Quarterly 49:501-534

Fleischer H (2018e) Comparative Corporate Governance in Closely Held Corporations. In: Gordon JN, Ringe WG (eds) The Oxford Handbook of Corporate Law and Governance. Oxford University Press, Oxford, pp 679-718

Fleischer V (2003-2004) The Rational Exuberance of Structuring Venture Capital Startups. Tax Law Review 57:137-184. UCLA School of Law, Law \& Econ Research Paper No. 03-20

Freshfields Bruckhaus Deringer LLP (2021) US SPAC Boom Spreads to Europe with Recent Amsterdam and Frankfurt SPAC Listings and Potential Reform in London, March

Gao X, Ritter JR, Zhu Z (2013) Where Have All the IPOs Gone? Journal of Financial and Quantitative Analysis 48(6):1663-1692

Ghetti R (2018) Unification, Harmonisation and Competition in European Company Forms. European Business Law Review 29(5):813-842

Gill KP (2021) Testimony of Keith Patrick Gill Before the United States House of Representatives Committee on Financial Services (Game Stopped? Who Wins and Loses When Short Sellers, Social Media, and Retail Investors Collide, February 18, 2021)

Gilson RJ (2003) Engineering a Venture Capital Market: Lessons from the American Experience. Stanford Law Review 55:1067-1103

Gilson RJ, Hansmann H, Pargendler M (2011) Regulatory Dualism as a Development Strategy: Corporate Reform in Brazil, the United States, and the European Union. Stanford Law Review 63(3):475-537

Gilson SC (2012) Coming Through in a Crisis: How Chapter 11 and the Debt Restructuring Industry Are Helping to Revive the U.S. Economy. Journal of Applied Corporate Finance 24(4):23-35 
Gompers PA, Gornall W, Kaplan SN, Strebulaev IA (2016) How Do Venture Capitalists Make Decisions? NBER Working Paper No. 22587, September 2016

Gompers PA, Lerner J (2001) The venture capital revolution. Journal of Economic Perspectives 15(2):145-168

Goode RM (1998) Commercial Law in the Next Millenium. The Hamlyn Lectures. Forty-ninth Series. Sweet \& Maxwell, London

Gornall W, Strebulaev IA (2020) Squaring Venture Capital Valuations with Reality. Journal of Financial Economics 135(1):120-143

Green JM, Coyle JF (2016) Crowdfunding and the Not-So-Safe SAFE. Virginia Law Review Online 102:168-182

Günther D (2021) Special Purpose Acquisition Companies und die Ineffizienz des Kapitalsystems. Walter de Gruyter $\mathrm{GmbH}$, Berlin and Boston

Han B, Hirshleifer DA, Walden J (2019) Visibility Bias in the Transmission of Consumption Beliefs and Undersaving. NBER Working Paper No. 25566, February 2019. Revised October 2020

Hanley KW (2018) Chapter 2. The Economics of Primary Markets. In: Fox MB, Glosten LR, Greene EF, Patel MS (eds) Securities Market Issues for the 21st Century. Prepared in connection with The New Special Study a project of Columbia Law School \& Columbia Business School's Program in the Law and Economics of Capital Markets. Independently published, pp 34-100

Hansen JL (2007) A Scandinavian Approach to Corporate Governance. Scandinavian Studies in Law 50:125-142

Harrer H, Erwe P (1998) Der Neue Markt der Frankfurter Wertpapierbörse im Vergleich zu NASDAQ und EASDAQ. Recht der internationalen Wirtschaft 44(9):661-674

Harwood A, Konidaris T (2015) SME Exchanges in Emerging Market Economies: A Stocktaking of Development Practices. Policy Research Working Paper 7160. Finance and Markets Global Practice Group, World Bank Group, Washington, D.C.

Heminway JM (2017) Selling Crowdfunded Equity: A New Frontier. Oklahoma Law Review 70(1):189-213

Heyman DK (2007) From Blank Check to SPAC: the Regulator's Response to the Market, and the Market's Response to the Regulation. Entrepreneurial Business Law Journal 2(1):531 $-552$

Hill J (2021) UK Listing Review. Chairman Jonathan Hill, 3 March 2021

Hirschman AO (1970) Exit, Voice, and Loyalty: Responses to Decline in Firms, Organizations, and States. Harvard University Press, Cambridge, Mass.

Hirshleifer DA (2015) Behavioral Finance. Annual Review of Financial Economics 7:133-159

Hoffman DL, Radojevich-Kelley N (2012) Analysis of Accelerator Companies: An Exploratory Case Study of Their Programs, Processes, and Early Results. Small Business Institute ${ }^{\circledR}$ Journal 8(2):54-70

Hopt KJ (2019b) Der Aufsichtsrat - Bedeutungswandel, Konvergenz, unternehmerische Mitverantwortung, Pflichten- und Haftungszuwachs. Zeitschrift für Unternehmens- und Gesellschaftsrecht 48(4):507-543. Max Planck Private Law Research Paper No. 19/17

Hopt KJ (2021) Corporate Governance of Banks and Financial Institutions: Economic Theory, Supervisory Practice, Evidence and Policy. European Business Organization Law Review 22(1):13-37 
Horton BJ (2019) Spotify's Direct Listing: Is it a Recipe for Gatekeeper Failure? SMU Law Review 72(1):177-214

Hu HTC, Black BS (2006a) The New Vote Buying: Empty Voting and Hidden (Morphable) Ownership. Southern California Law Review 79:811-908

Hu HTC, Black BS (2006b) Empty Voting and Hidden (Morphable) Ownership: Taxonomy, Implications, and Reforms. Business Lawyer 61:1011-1069

Hu HTC, Black BS (2007) Hedge funds, insiders, and the decoulling of ecnomic and voting ownership: Empty Voting and Hidden (Morphable) Ownership. Journal of Corporate Finance 13(2-3):343-367

Ibrahim DM (2008) The (Not So) Puzzling Behavior of Angel Investors. Vanderbilt Law Review 61(5):1405-1452

Ibrahim DM (2013) Should Angel-Backed Start-Ups Reject Venture Capital? Michigan Journal of Private Equity and Venture Capital Law 2(2):251-269

Ibrahim DM (2015) Equity Crowdfunding: A Market for Lemons? Minnesota Law Review 100:561-607

Ibrahim DM (2019) Public or Private Venture Capital? Washington Law Review 94:1137-1174

Ignatyeva E, Rauch C, Wahrenburg M (2013) Analyzing European SPACs. The Journal of Private Equity 17(1):64-79

Jaffe MD, Rodgers G, Gutierrez H (2018) Spotify Case Study: Structuring and Executing a Direct Listing. Harvard Law School Forum on Corporate Governance and Financial Regulation, 5 July 2018

Jensen MC (1989) Eclipse of the Public Corporation. Harvard Business Review 67(5):61-74

Jensen MC, Meckling WH (1976) Theory of the Firm: Managerial Behavior, Agency Costs and Ownership Structure. Journal of Financial Economics 3(4):305-360

Jentsch V (2019) Board Composition, Ownership Structure and Firm Value: Empirical Evidence from Switzerland. European Business Organization Law Review 20:203-254

Jiang F, Kim KA (2015) Corporate Governance in China: A modern perspective. Journal of Corporate Finance 32:190-216

Kahle KM, Stulz RM (2017) Is the US Public Corporation in Trouble? Journal of Economic Perspectives 31(3):67-88

Kaplan SN, Strömberg P (2001) Venture Capitalists as Principals: Contracting, Screening, and Monitoring. American Economic Review 91(2):426-430

Kaplan SN, Strömberg P (2003) Financial Contracting Theory Meets the Real World: An Empirical Analysis of Venture Capital Contracts. Review of Economic Studies 70(2):281-315

Kaplan SN, Strömberg P (2004) Characteristics, Contracts, and Actions: Evidence from Venture Capitalist Analyses. Journal of Finance, 59(5):2177-2210

Kenney M, Zysman J (2019) Unicorns, Cheshire cats, and the new dilemmas of entrepreneurial finance. Venture Capital 21(1):35-50

Kieser A (2004) The Americanization of Academic Management Education in Germany. Journal of Management Inquiry 13(2):90-97

Klausner M, Ohlrogge M, Ruan E (2021) A Sober Look at SPACs. ECGI Working Paper Series in Finance, Working Paper $N^{\circ} 746 / 2021$, April

Kröner A, Jones K (2016) Börse startet Wachstums-Segment: Jetzt kommt der neue Neue Markt, manager-magazin, 22 November 2016 
Lafer G (2017) The One Percent Solution: How Corporations Are Remaking America One State at a Time. ILR Press, an Imprint of Cornell University Press, Ithaca and London

Lakicevic M, Shachmurove Y, Vulanovic M (2014) Institutional Changes of Specified Purpose Acquisition Companies (SPACs). The North American Journal of Economics and Finance 28:149-169

LaPorta R, Lopez-de-Silanes F, Shleifer A, Vishny R (2000) Investor Protection and Corporate Governance. Journal of Financial Economics 58 (1-2):3-27

Lee CM, Miller WF, Hancock MG, Rowen HS (eds) (2000) The Silicon Valley Edge: A Habitat for Innovation and Entrepreneurship. Stanford University Press, Stanford

Lee PM, Pollock TG, Jin K (2011) The contingent value of venture capitalist reputation. Strategic Organization 9(1):33-69

Lekvall P (ed) (2014) The Nordic Corporate Governance Model. With comment by Ronald Gilson (2014) SNS Förlag, Stockholm

Lin L (2020) Contractual Innovation in China's Venture Capital Market. European Business Organization Law Review 21:101-138

Lu L, Ye N (2018) Chinese Depositary Receipts: What They Are, How They Work and Why This Represents a Golden Opportunity. Butterworths Journal of International Banking and Financial Law 33(8):529-532

Macey JR, O'Hara M (2005) From Markets to Venues. Securities Regulation in an Evolving World. Stanford Law Review 58:563-599

Mäntysaari P (2005) Comparative Corporate Governance: Shareholders as a Rule-maker. Springer, Berlin Heidelberg

Mäntysaari P (2010a) The Law of Corporate Finance: General Principle and EU Law. Volume I: Cash Flow, Risk, Agency, Information. Springer, Berlin Heidelberg

Mäntysaari P (2010b) The Law of Corporate Finance: General Principle and EU Law. Volume II: Contracts in General. Springer, Berlin Heidelberg

Mäntysaari P (2010c) The Law of Corporate Finance: General Principles and EU Law. Volume III: Funding, Exit, Takeovers. Springer, Berlin Heidelberg

Mäntysaari P (2012) Organising the Firm: Theories of Commercial Law, Corporate Governance and Corporate Law. Springer, Berlin Heidelberg

Mäntysaari P (2015) EU Electricity Trade Law: The Legal Tools of Electricity Producers in the Internal Electricity Market. Springer, Cham

Mayer C (1990) Financial Systems, Corporate Finance, and Economic Development. In: Hubbard G (ed) Asymmetric Information, Corporate Finance, and Investment. University of Chicago Press, Chicago, pp 307-332

Milhaupt CJ (2017) Chinese Corporate Capitalism in Comparative Context. In: Chen W (ed) The Beijing Consensus? How China Has Changed the Western Ideas of Law and Economic Development. Cambridge University Press, Cambridge

Moedl M (2019) Two's a Company, Three's a Crowd: Deal Breaker Terms in Equity Crowdfunding for Prospective Venture Capital. Max Planck Institute for Innovation \& Competition Research Paper No. 18-25. Published in Small Business Economics (2020)

Morley J (2014) The Separation of Funds and Managers: A Theory of Investment Fund Structure and Regulation. The Yale Law Journal 123(5):1118-1287

Morrison \& Foerster LLP (2017) ECG Corporate Governance Practices: A survey and related resources. February 2017 
Munter P (2021) Financial Reporting and Auditing Considerations of Companies Merging with SPACs. U.S. Securities and Exchanges Commission. Public Statement. Paul Munter, Acting Chief Accountant, March 31, 2021

Napps EA (2021) Power to the Traders? A Look at the Reddit-Driven Surge of GameStop and Robinhood's Subsequent Suspension of Meme Stocks. Wake Forest Law Review, blog, 23 February 2021

Norton Rose Fulbright (2021) SPACs: The London alternative. October 2020. Updated in March 2021 to include reference to publication of the UK Listing Review.

OECD (2015c) New Approaches to SME and Entrepreneurship Financing: Broadening the Range of Instruments. OECD Publishing, Paris

OECD (2019a) Financing SMEs and Entrepreneurs 2019: An OECD Scoreboard. OECD Publishing, Paris

OECD (2019b) Initial Coin Offerings (ICOs) for SME Financing. OECD Publishing, Paris Ostrom E (2005) Understanding Institutional Diversity. Princeton University Press, Princeton Ostrom E (2010) Beyond Markets and States: Polycentric Governance of Complex Economic Systems. Prize Lecture, December 8, 2009. In: Grandin K (ed) La Prix Nobel. Nobel Foundation, Stockholm, pp 408-444 and American Economic Review 100(3):641-672

Pan W, Altshuler Y, Pentland A (2012) Decoding Social Influence and the Wisdom of the Crowd in Financial Trading Network. In: 2012 International Conference on Privacy, Security, Risk and Trust and 2012 International Conference on Social Computing. Institute of Electrical and Electronics Engineers, pp 203-209

Paul T (2015) The Effect of Social Media on Trading Behavior: Evidence From Twitter. Wharton Research Scholars 131

Plückelmann K (2000) Der Neue Markt der Deutsche Börse AG. Peter Lang Gmbh, Frankfurt am Main

Posner E (2005) Sources of Institutional Change: The Supranational Origins of Europe's New Stock Markets. World Politics 58(1):1-40

PwC (2016) The future of research: Impact of MiFID II on research for investment firms. MiFID II - Discussion paper, September 2016

Reddy B (2020) Finding the British Google: Relaxing the Prohibition of Dual-Class Stock from the Premium-Tier of the London Stock Exchange. The Cambridge Law Journal 79(2):315 $-348$

Riemer DS (2007) Special Purpose Acquisition Companies: SPAC and SPAN, or Blank Check Redux. Washington University Law Review 85:931-967

Rose P, Solomon SD (2016) Where Have All the IPOs Gone? The Hard Life of the Small IPO. Harvard Business Law Review 6:83-128

Sahlman WA (1990) The Structure and Governance of Venture-Capital Organizations. Journal of Financial Economics 27(2):473-521

Salmon F (2014) No need for banks in an era of intellectual capital. Financial Times, 22 August 2014

Schroeder D, Thomsen S (2021) Foundation Ownership and Financial Performance - a Global Analysis. Working paper presented at Nordic Corporate Governance Network on 28 June 2021

Schumacher B (2020) A New Development in Private Equity: The Rise and Progression of Special Purpose Acquisition Companies in Europe and Asia. Northwestern Journal of International Law \& Business 40(3):391-415 
SEC (2016a) The Office of Investor Education and Advocacy, International Investing, December 8, 2016

Senor D, Singer S (2011) Start-up Nation: The Story of Israel's Economic Miracle. Twelve, New York

Shearman \& Sterling (2001) Genügt das deutsche Kapitalmarktrecht internationalen Standards? In: Deutsche Börse AG (ed) Neuer-Markt-Report. Zugang zu Europäischen Kapitalmarkt - Schlüssel für Wachstum. Frankfurt am Main, pp 54-93

Shleifer A, Vishny R (1986) Large shareholders and corporate control. Journal of Political Economy 94:461-488

Simons K (1999) Should U.S. Investors Invest Overseas? New England Economic Review, Federal Reserve Bank of Boston, issue November/December, pp 29-40

Smerznak I (2021) GameStop: What the Actions of a Group of Redditors and the Robinhood Trading Platform Can Tell Us About the State of Securities Trading. University of Miami Law Review, blog, 15 February 2021

Special Study of Securities Markets (1963a) Report of Special Study of Securities Markets of the Securities and Exchange Commission. 88th Congress, 1st Session. House Document No. 95, Pt. 1. U.S. Government Printing Office, Washington

Steil B (2001) Borderless trading and developing securities markets. In: Litan R, Masson P, Pomerleano M (eds) Open Doors: Foreign Participation in Financial Systems in Developing Countries, Brookings Institution Press, Washington D.C., pp 327-350

Suchman MC, Cahill ML (1996) The Hired Gun as Facilitator: Lawyers and the Suppression of Business Disputes in Silicon Valley. Law \& Social Inquiry 21(3):679-712

Tenev V (2021) Testimony of Vladimir Tenev, Robinhood Markets, Inc., Before the United States House of Representatives Committee on Financial Services (Game Stopped? Who Wins and Loses When Short Sellers, Social Media, and Retail Investors Collide, February 18, 2021)

Thaler RH, Sunstein CR (2008) Nudge: Improving Decisions about Health, Wealth, and Happiness. Yale University Press, New Haven

Thomsen S (1996) Foundation Ownership and Economic Performance. Corporate Governance 4(4):212-221

UNDP (2017) Financing Solutions for Development - Crowdfunding

UNDP (2018) Financing the 2030 Agenda: An Introductory Guidebook for UNDP Country Offices

Vismara S, Paleari S, Ritter RJ (2012) Europe's second markets for small companies. European Financial Management 18:352-388

Vitols S (2001) Frankfurt's Neuer Markt and the IPO Explosion: Is Germany on the Road to Silicon Valley? Economy and Society 30(4):553-564

Vitols S, Engelhardt L (2005) National institutions and high tech industries: A varieties of capitalism perspective on the failure of Germany's Neuer Markt. WZB Discussion Paper, No. SP II 2005-03, Wissenschaftszentrum Berlin für Sozialforschung (WZB), Berlin

von Clausewitz C (1832) Vom Kriege. Bei Ferdinand Dümmler, Berlin

von Hein J (2008) Die Rezeption US-amerikanischen Gesellschaftsrechts in Deutschland. MaxPlanck-Institut für ausländisches und internationales Privatrecht. Beiträge zum ausländischen und internationalen Privatrecht 87. Mohr Siebeck, Tübingen 
Weild D, Kim E, Newport L (2013) Making Stock Markets Work to Support Economic Growth: Implications for Governments, Regulators, Stock Exchanges, Corporate Issuers and their Investors. OECD Corporate Governance Working Papers, No. 10. OECD Publishing, Paris

Williamson JJ (2013) The JOBS Act and Middle-Income Investors: Why It Doesn't Go Far Enough. Yale Law Journal 122(7):2069-2080

Williamson OE (1984) The Incentive Limits of Firms: A Comparative Institutional Assessment of Bureaucracy. Review of World Economics (Weltwirtschaftliches Archiv) 120(4):736-763

Winston \& Strawn LLP (2021) French SPAC: The Keys to a Successful Transaction. February 3, 2021. Originally published in Fusions \& Acquisitions Magazine

Wong A, Bhatia M, Freeman Z (2009) Angel finance: the other venture capital. Strategic Change 18:221-230

World Economic Forum (2015) The Future of Financial Services: How disruptive innovations are reshaping the way financial services are structured, provisioned and consumer. An Industry Project of the Financial Services Community. Prepared in collaboration with Deloitte. Final Report, June 2015

World Federation of Exchanges (2018) WFE Report on SME Exchanges

Wroldsen JS (2013) The Social Network and the Crowdfund Act: Zuckerberg, Saverin, and Venture Capitalists' Dilution of the Crowd. Vanderbilt Journal of Entertainment and Technology Law 15(3):583-635

Xu W, Zhu S, Wu Z (2020) Building a Junior Stock Exchange: Lessons from China. European Business Organization Law Review 21:139-170

Yamanaka T (2018) Corporate Boards in Europe and Japan: Convergence and Divergence in Transition. European Business Organization Law Review 19:503-525 
